\title{
Article \\ Structure of Anther Epidermis and Endothecium, Production of Pollen, and Content of Selected Nutrients in Pollen Grains from Six Rubus idaeus L. Cultivars
}

\author{
Mikołaj Kostryco and Mirosława Chwil *
}

Citation: Kostryco, M.; Chwil, M. Structure of Anther Epidermis and Endothecium, Production of Pollen, and Content of Selected Nutrients in Pollen Grains from Six Rubus idaeus L. Cultivars. Agronomy 2021, 11, 1723. https://doi.org/10.3390/ agronomy 11091723

Academic Editor: Pilar S. Testillano

Received: 13 July 2021

Accepted: 25 August 2021

Published: 28 August 2021

Publisher's Note: MDPI stays neutral with regard to jurisdictional claims in published maps and institutional affiliations.

Copyright: (c) 2021 by the authors. Licensee MDPI, Basel, Switzerland. This article is an open access article distributed under the terms and conditions of the Creative Commons Attribution (CC BY) license (https:/ / creativecommons.org/licenses/by/ $4.0 /)$.
Department of Botany and Plant Physiology, University of Life Sciences in Lublin, 15 Akademicka Street, 20-950 Lublin, Poland; mikolaj.kostryco@up.lublin.pl

* Correspondence: miroslawa.chwil@up.lublin.pl

\begin{abstract}
Poland is the largest European Union producer of Rubus idaeus. This species provides insects with nectar and pollen from June to September. The rationale behind the present research is the increasing commercial production and the use of food attractants for pollinators increasing fruit yields. The intensive search for phytochemicals applicable in industry and phytotherapy together with the unavailability of data on anther epidermis and endothecium structure justify undertaking these investigations. The pollen mass, the content of elements, protein, and fat, as well as the composition of amino acids and fatty acids in the pollen of six $R$. idaeus cultivars were compared. In terms of pollen production, the cultivars ranked as follows: 'Pokusa' < 'Polana' < 'Glen Ample' < 'Polka' < 'Radziejowa' < 'Laszka'. The protein content $(26-31 \%)$ in the pollen indicates its good quality and high attractiveness. Exogenous amino acids, including those with dietary importance, constituted a substantial proportion (33-39\%). The content of MUFAs and PUFAs was 32-47\% and 3.7-9.1\%, respectively. The presence of elements that determine the nutritional value and proper development of pollen was detected in the mineral composition of the exine. The data on the epidermis and endothecium structure provide new information about the micromorphology, anatomy, ultrastructure of and generative organs and auxiliary criteria in the taxonomy of related species.
\end{abstract}

Keywords: proteins; amino acids; fatty acids; red raspberry; minerals; pollen productivity

\section{Introduction}

The production of raspberries has recently doubled due to the high value and increased interest in this product [1,2]. Global commercialization has contributed to a rapid increase in R. idaeus cultivation $[3,4]$. Poland is the largest in the European Union, the second in Europe, and the fifth in the world producer of raspberries (FAO 2019) [5]. Given the profitability of production of this plant, the area of cultivation of biennial fruiting cultivars is increasing in favor of repeated fruiting cultivars (approximately 40-60\%). The most popular biennial fruiting cultivars are 'Glen Ample', 'Laszka', and 'Radziejowa', whereas 'Polana', 'Polka', and 'Pokusa' are the most popular repeated fruiting cultivars [6,7]. Raspberry shrubs provide pollinating insects with pollen and nectar [8].

Pollen is a rich source of various biologically active chemical compounds with healthenhancing values and phytotherapeutic effects $[9,10]$. The health-promoting properties of pollen confirm the relevance of its use in pharmaceutical, cosmetic, and food industries [11-13]. Considerations of the potential use of pollen as a component of functional food should take into account the structure of the anther, which serves as a protective and nutritional function for maturing pollen grains as well as the structure of the pollen grain wall, mainly the sporopollenin-saturated exine [14-18]. 


\subsection{Anther Epidermis and Andothecium}

Epidermis. Stamens are important in phylogenesis. During development, anther epidermis cells undergo modifications before differentiation into adaxial and abaxial epidermis $[14,19]$. Cutin, waxes, and polysaccharides are constituents of the anther epidermis cuticle. Cutin is formed by polymerization of hydroxylated and epoxylated fatty acids, i.e., palmitic, stearic, and ferulic acids. Waxes contain long-chain fatty acids, alkanes, alkenes, and alcohols. In turn, polysaccharides form the fibrillar structure of the cuticle [20-23].

Lipid precursors formed in tapetum cells participate in cuticle biosynthesis and are then transported to the surface of the anther epidermis and microspores. The translocation of fatty compounds is regulated by tapetum genes, some of which are involved in pollen-pistil interactions and participate in the oxidative pathway of v-hydroxy fatty acids (palmitic and stearic) or regulate the formation of anther cuticle and pollen exine sculpture [23-28].

Endothecium. Anther maturation involves complex metabolic pathways and is associated with dehiscence and release of pollen grains [14,29,30]. These transformations are determined by auxins, jasmonic acid, and lignification of secondary cell walls of the endothecium. The function of auxins is regulated by the gene encoding transcription factor MYB26 in the lignin biosynthetic pathway. Lignification of endothecium walls is accompanied by disappearance of the middle layer and tapetum cells as well as formation of characteristic thickenings and the activity of phosphotransfer proteins $[29,31,32]$. These histidine proteins participate in the multi-step cytokinin-signaling pathway as phosphorelay mediators. In turn, the chloroplast cystathionine $\beta$-synthase protein CBSX2 regulates the concentration of $\mathrm{H}_{2} \mathrm{O}_{2}$, thioredoxin, and jasmonic acid, as well as the formation of wall evaginations $[30,33]$. These transformations are mediated by the ROT VU-B SENSITIVE4 gene encoding a protein with DUF647 domain of undefined function, which influences the expression of secondary endothecium cell wall genes [34].

\subsection{Pollen as a Source of Nutrients}

Protein. The total protein content in pollen of various Rubus species ranges between 15 and 37\% [35-41]. Pollen of zoophilous and entomophilous species is richer in protein $(39.3 \%)$ than anemophilous ones $(25.8 \%)$ [41,42]. Pollen grain proteins are located on the surface of the exine, in intine layers, and in the cytoplasm. Intine proteins are released with enzymes through pores. They participate in the mutual recognition of pollen grains and stigma. Arabinogalactan proteins present near the pores and in the pollen tube are involved in the formation of the pollen tube wall [43-45]. In turn, other proteins exert an impact on pollen-pistil and plant-pollinator interactions. They are also engaged in pollen adhesion to the pistil stigma [42,45].

Proteins involved in the germination and pollen tube growth are encoded by respective genes; they activate cell membrane hydrogen ATPase required for these processes [46,47]. Various enzymes are responsible for penetration of the stigma surface, clearing the way of the pollen tube through the pistil style and providing the pollen tube with nutrient supply. These functions are positively correlated with the concentration of enzymes and proteins in pollen [42]. The Rab Geranylgeranyl Transferase enzyme together with proteins ACT11, AtRGTB1, and SFH3 are involved in the molecular stages of generative reproduction, as they support the germination and elongation of the pollen tube and the transport of sperm cells to the ovule [48].

Amino acids. The amino acid composition determines the flavor of pollen products and thus regulates insect visits to flowers. The total content of amino acids in pollen grains of species from the subfamily Rosoideae, Potentilla erecta, Rosa canina, and Rubus fruticosus, is in the range of 32.8-35\% [36,38]. Arginine, histidine, lysine, tryptophan, phenylalanine, methionine, threonine, leucine, isoleucine, and valine are essential for the development of honeybees. Some amino acids, including valine, leucine, and isoleucine influence the behavior and preferences of honeybees as well as the choice of pollen flow by other 
insects [42,49]. In addition to their nutritional role, amino acids are also an important tool helpful in the differentiation of honey types [50].

Lipids. Pollen is a rich source of unsaturated fatty acids, which are important dietary components [51,52]. In frozen and dried pollen containing $89.9 \%$ of Rubus sp. grains, the total fat content was estimated at 3.7 and $4.4 \%$, respectively [52]. The dominant fatty acids in Rubus sp. pollen were $\alpha$-linolenic (25.8-28.8\%), linoleic (20.8-24.8\%), and palmitic (20.2-28.8\%) acids [53]. In turn, in bee pollen baskets with Rubus-type pollen grains accounting for $5.4-27.8 \%, 19$ fatty acids were distinguished, with predominance of linolenic acid $(24.6 \%)$, isopalmitic acid $(23.2 \%)$, palmitic acid $(16.4 \%)$, oleic acid $(8.8 \%)$, and linoleic acid (8.1\%) [51]. Pollen rich in oleic and palmitic acid is very important in honeybee nutrition. Pollen grains with high contents of linoleic, linolenic, myristic, and dodecanoic acids largely inhibit the growth of Paenibacillus larvae and Melissococcus plutonius and other microorganisms causing infectious bacterial disease in brood [54]. Certain lipids may serve as ligands for allergenic proteins. The atopic reaction is associated with the presence of saturated and unsaturated fatty acids, glycophospholipids, sphingolipids, sterols, and oxylipids as well as lipopolysaccharides from the microbiome on the pollen surface [55]. The fatty acid profile in pollen plays an important role in plant chemotaxonomy, and behenic acid and isopalmitic acid are characteristic of Rubus sp. pollen grains.

Mineral elements and other selected active compounds. Considerable concentrations of mineral elements, especially $\mathrm{K}, \mathrm{Ca}, \mathrm{Mg}, \mathrm{Zn}, \mathrm{Fe}, \mathrm{Mn}$, and $\mathrm{Cu}$, which can supplement the diet, were found in pollen grain samples of various species [56,57]. These elements may serve as a valuable dietary supplement. Sugars $(6.7 \%)$, including glucose $(21 \%)$ and fructose $(23.2 \%)$, are important components of Rubus pollen [38,51]. Additionally, Rubus pollen contains flavonoids, phenolic acids, sterols, carotenoids, vitamins, and polyphenols [58-61]. The rationale for the undertaken research is the increasing commercial production of $R$. idaeus and the need to use food attractants for pollinators increasing the fruit yield. The search for natural bioactive substances applicable in various industries and in the prophylaxis and phytotherapy of certain diseases as well as the unavailability of data on the content of protein, amino acids, fatty acids, and mineral elements in pollen grains and on pollination-determining pollen production in widely cultivated red raspberry varieties justify undertaking the present investigations. The study also addresses the fact that the available literature provides fragmentary reports on the micromorphology and ultrastructure of the epidermis and endothecium of some anther wall layers protecting the important site of microspore formation.

The aim of the report was to: (i) determine the micromorphology, (ii) anatomy, and (iii) ultrastructure of the epidermis and anther endothecium, (iv) compare pollen mass, (v) total protein content, (vi) total fat content, (vii) qualitative and quantitative composition of amino acids and (viii) fatty acids, and (ix) determine the content of selected elements in the exine of pollen grains in six $R$. idaeus cultivars.

\section{Materials and Methods}

\subsection{Plant Material}

The research was carried out in 2016-2018 on Rubus idaeus: three biennial ('Glen Ample', 'Laszka', and 'Radziejowa') and three repeated ('Polana', 'Polka', and 'Pokusa') fruiting cultivars. The R. idaeus shrubs grew on a commercial plantation located in Blinów II ( $50^{\circ} 52^{\prime} 57.03^{\prime \prime} \mathrm{N} ; 22^{\circ} 23^{\prime} 2.663^{\prime \prime}$ E), Lublin Province (raspberry plantation region), southeastern Poland. Flowers were collected at the bud burst stage to compare the pollen mass, total protein and total fat contents, the quantitative and qualitative composition of amino acids and fatty acids, and selected elements in pollen. Moreover, the ornamentation of the surface of the anther epidermis cells, their anatomical and ultrastructural traits, and the endothecium of the stamen anther were described.

Meteorological data, i.e., the average daily air temperature and precipitation in the period from May to August 2016-2018 were presented for the region where the raspberry cultivars were grown (Figures 1 and 2). 


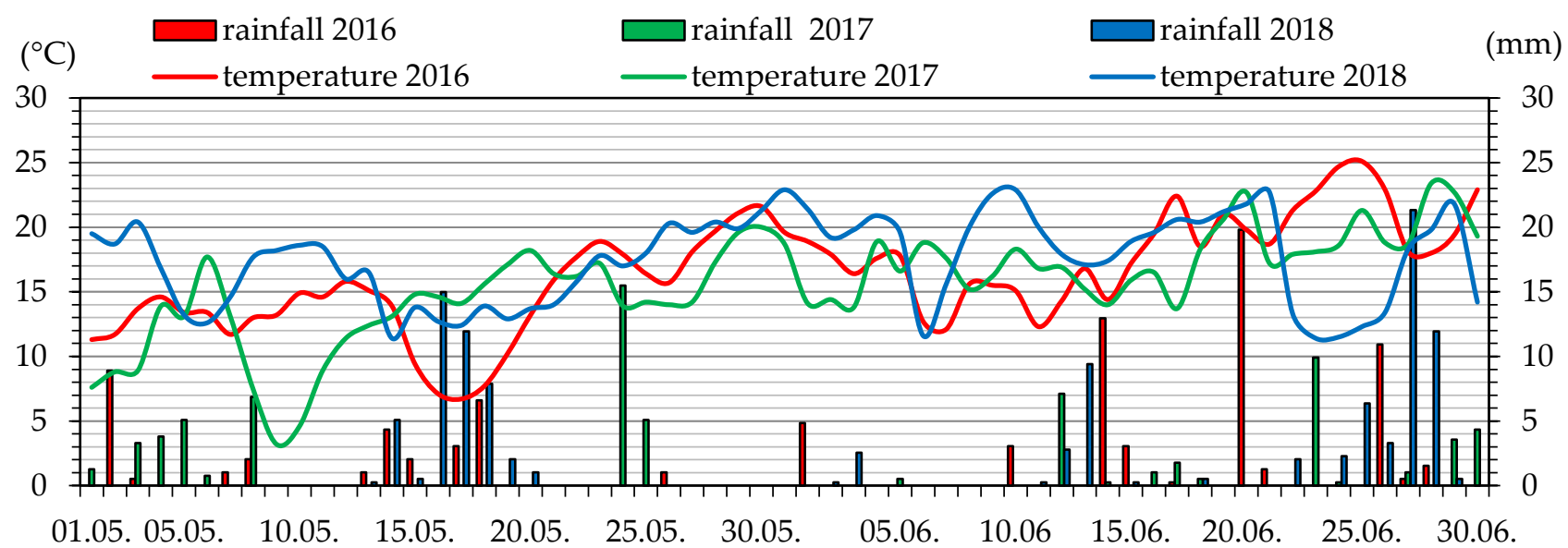

Figure 1. Average daily values of air temperature and precipitation in May and June 2016-2018 in Blinów II.

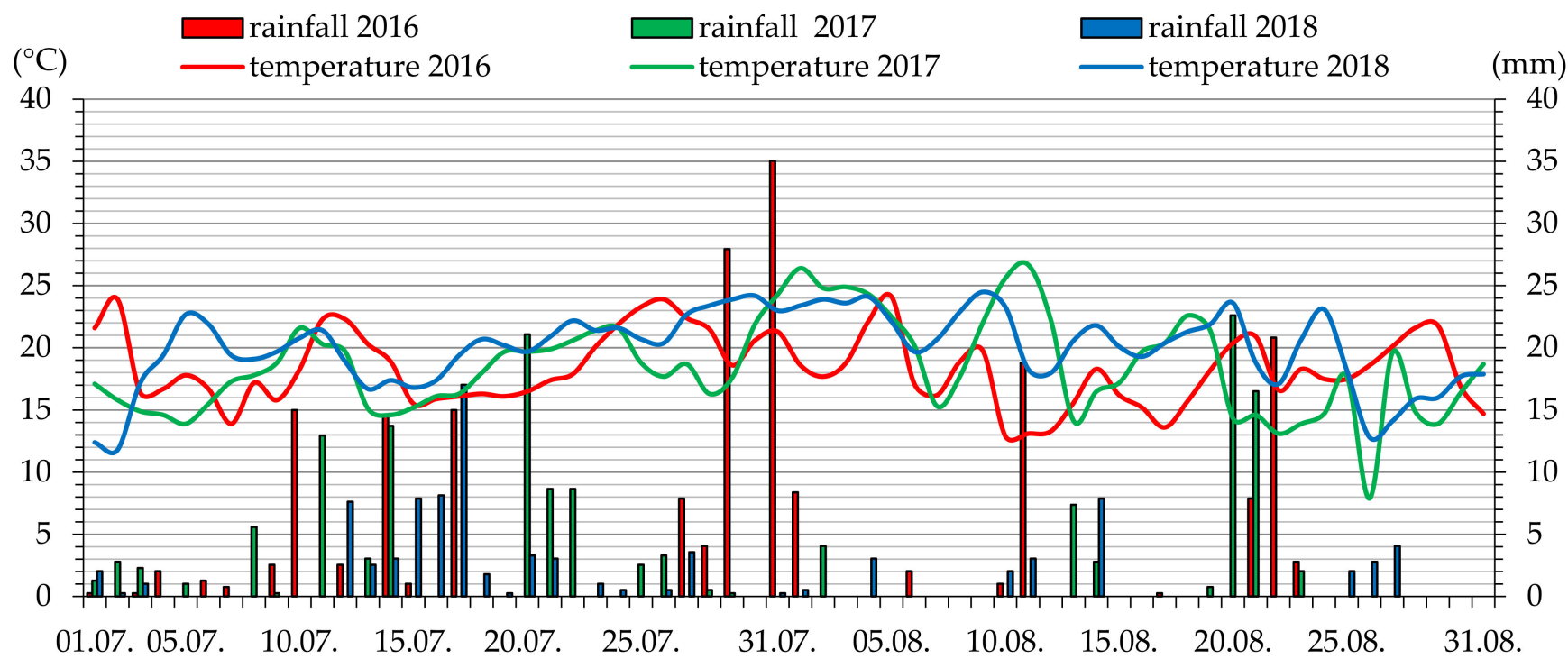

Figure 2. Average daily values of air temperature and precipitation in July and August 2016-2018 in Blinów II.

\subsection{Fixation of Material for Microscopy}

For comparative studies of the micromorphology of the epidermis of filaments and anthers $(\mathrm{n}=10)$ and the anatomy and ultrastructure of epidermis and anther endothecium cells $(n=10), 10$ randomly selected inflorescences and 10 flowers at the initial stage of flowering were collected from each cultivar. Two stamens were dissected from the flowers (fragments of filaments and entire closed anthers). The plant material was fixed in $4 \%$ glutaraldehyde for $6 \mathrm{~h}$ at room temperature. Next, the samples were transferred to $0.01 \mathrm{M}$ phosphate buffer, $\mathrm{pH} 7.0$, and stored at $4{ }^{\circ} \mathrm{C}$ for $48 \mathrm{~h}$. Afterwards, stamen fragments were dehydrated with appropriate solutions depending on the intended use in light, scanning electron, and transmission electron microscopes.

\subsection{Light Microscopy}

Fixed filament and anther samples were washed in phosphate buffer twice, contrasted in $1.5 \%$ osmium tetroxide for $1.5 \mathrm{~h}$, and rinsed with distilled water. Next, they were transferred to a $0.5 \%$ aqueous uranyl acetate solution and kept for $2 \mathrm{~h}$ at $20^{\circ} \mathrm{C}$. For the light and transmission electron microscopic observations, the plant material was dehydrated in a series of ethyl alcohol at the concentrations of $15,30,50,70,90,96$, and $99.8 \%$ for $15 \mathrm{~min}$ 
in each solution and twice in anhydrous ethanol. The dehydrated sections of the anthers were embedded in Spurr Low Viscosity resin and polymerized at $60^{\circ} \mathrm{C}$ for $48 \mathrm{~h}$.

Semi-thin transverse sections of the fixed material were made for the anatomical observations under a light microscope. Sections of $0.8-1.0 \mu \mathrm{m}$ thick were cut with a glass knife using a Reichert Ultracut $\mathrm{S}$ microtome (Leica, Vienna, Austria), dried, and stained with $1 \%$ toluidine blue and $1 \%$ azure II $(1: 1)$ at $60{ }^{\circ} \mathrm{C}$ for $5 \mathrm{~min}$. After rinsing with distilled water and $5 \%$ ethyl alcohol, the preparations were dried. The comparative anatomical observations of anther epidermis and endothecium cells were performed using a Nikon Eclipse 90i bright field microscope (Nikon, Tokyo, Japan).

\subsection{Scanning Electron Microscopy (SEM)}

Fixed anther and filament samples from the R. idaeus cultivars were dehydrated in an acetone series: $15,30,50,70,90$, and $99.5 \%$ (for $15 \mathrm{~min}$ at each concentration) and twice in anhydrous acetone. Next, the samples were critically dried in liquid $\mathrm{CO}_{2}$ in an Emitech K850 dryer (Emitech, Ashford, UK) and gold sputtered using an Emitech K550X sputter coater (Emitech, Ashford, UK). The observations of the stamen epidermis surface and photographic documentation were made using a Tescan Vega II LMU scanning electron microscope (Tescan, Brno, Czech Republic).

\subsection{Transmission Electron Microscopy (TEM)}

Ultrathin sections (70 $\mathrm{nm}$ thick) were cut from the fixed and resin-embedded anthers and stained with $8 \%$ uranyl acetate in $0.5 \%$ acetic acid for $40 \mathrm{~min}$. After rinsing with distilled water twice (10 min), the sections were contrasted with Reynolds reagent for $15 \mathrm{~min}$, washed with water again, and dried [62]. The observations of the ultrastructure of anther epidermis and endothecium cells at the initial stage of flowering were performed using the Tecnai Spirit G2 transmission electron microscope (FEI Company, Hillsboro, OR, USA).

\subsection{Number and Length of Stamens}

The stamens were counted in single flowers at the initial stage of flowering. To determine the number of stamens, 16 inflorescences were randomly selected from different plants of each $R$. idaeus cultivar. One flower $(n=16)$ was taken from an identical site in each inflorescence and the stamens were counted. The number of stamens is a characteristic feature of a given variety and is necessary for determination of the mass of pollen produced by one flower. Additionally, two normally formed stamens with a closed anther were sampled from the outer whorl of each flower and their length was measured $(n=30)$.

\subsection{Pollen Mass}

The mass of pollen produced by the $R$. idaeus flowers was determined with the modified ether-weight method proposed by Warakomska [63]. The stamens in the flowers of individual cultivars were counted to determine the mass of pollen produced by one flower in the consecutive years. The pollen mass was calculated for 100 stamens and converted into 10 flowers. Pollen was collected from the flowers at the bud burst stage when the shrubs were in full bloom. In the subsequent study years, 12 samples of pollen were collected from each cultivar. Pollen from 100 well-developed closed anthers collected from 10 randomly selected inflorescences constituted one sample.

\subsection{Energy Dispersive Spectroscopy (EDS) Microanalysis of Elements}

The microanalysis of elements in pollen grains was performed with the energy dispersive X-ray technique using a Bruker X-Flash Energy Dispersive Spectroscopy (EDS) detector, model X-Flash $123 \mathrm{eV}$ coupled with a Zeiss Ultra Plus scanning electron microscope (Zeiss, Oberhofen, Germany). The elemental analyses were performed on the surface of 25 randomly selected pollen grains from each cultivar at a live time of $120 \mathrm{~s}$, a dead time of less than $1 \%$, and $20 \mathrm{keV}$ beam energy. At this energy, the electron beam penetrated the pollen grain wall to a depth of $2 \mu \mathrm{m}$. After collecting the spectrum, the data were collected 
and converted mathematically using the standardless method; the results were expressed in weight percent (wt. \%).

\subsection{Total Fat Content and Qualitative and Quantitative Fatty Acid Composition}

Total fat content in the pollen grains was determined using the Soxhlet method. The quantitative and qualitative analysis of fatty acids was performed after saponification with a methanolic potassium hydroxide solution in accordance with Polish Standard PNEN ISO 12966-1 [64]. Next, esterification was performed by addition of a methanolic boron trifluoride solution and separation with hexane and a saturated sodium chloride solution. The hexane layer was collected into a glass vial and dried with the use of anhydrous sodium sulfate. The chromatographic analysis was carried out using a Varian 450-GC gas chromatograph (Varian Inc., Temecula, CA, USA equipped with an 1177 Split/Splitless injector (temperature $250{ }^{\circ} \mathrm{C}$ ) and a Select ${ }^{\mathrm{TM}}$ Biodiesel CP9080 for FAME capillary column (30 m; $0.32 \mathrm{~mm} ; 0.25 \mu \mathrm{m}$ ) (Agilent Technologies Inc., Santa Clara, CA, USA). The stationary phase consisted of Select Biodiesel for FAME Fused Silica, a column oven with an initial temperature of $100{ }^{\circ} \mathrm{C}$ and a final temperature of $240{ }^{\circ} \mathrm{C}$, and an FID detector (temperature $270^{\circ} \mathrm{C}$ ). The carrier gas (helium) flow rate was $1.5 \mathrm{~mL} / \mathrm{min}$. The Galaxie ${ }^{\mathrm{TM}}$ Chromatography Data System Autosampler 1.9 SP2b software (Varian Inc., Temecula, CA, USA) was used for collection, integration, and computation of the results.

\subsection{Total Protein Content}

The total nitrogen content in the pollen samples $(n=3)$ from the analyzed cultivars was determined using the Kjeldahl method [65]. A FOSS Kjeltec 2300 analyzer (FOSS Co., Höganäs, Sweden) was used for determination of nitrogen. The total protein content was calculated using the protein ratio of 5.6 [66].

\subsection{Qualitative and Quantitative Amino Acid Composition}

The qualitative and quantitative amino acid composition in the pollen grains of the R. idaeus cultivars was determined using the Davies and Thomas method [67]. The pollen sample $(\mathrm{n}=3)$ was first placed in an analyzer tray (INGOS) and flooded with $6 \mathrm{M} \mathrm{HCl}$. The solution was saturated with nitrogen and hydrolyzed at $110{ }^{\circ} \mathrm{C}$ for $20 \mathrm{~h}$, cooled, and filtered. The hydrolyzate was evaporated using an RVO 400 SD vacuum evaporator at $50{ }^{\circ} \mathrm{C}$, washed with $1 \mathrm{~mL}$ of distilled water, and evaporated again. The dry residue in the vacuum flask was dissolved in $5 \mathrm{~mL}$ of citrate buffer, $\mathrm{pH}$ 2.2. The sample was dispensed onto a $35 \mathrm{~cm}$ long and $5 \mathrm{~mm}$ diameter column filled with ion exchange resin. Amino acids were separated using an AAA 400 amino acid analyzer (Ingos, Prague, Czech Republic) at temperature values $\mathrm{T}_{1}=60^{\circ} \mathrm{C}$ and $\mathrm{T}_{2}=63{ }^{\circ} \mathrm{C}$. The amino acids were derivatized into colored amino acid-ninhydrin complexes. The amino acids were identified with the use of a photometric detector at a wavelength of $570 \mathrm{~nm}$ and $440 \mathrm{~nm}$ for proline. The chromatogram was read in the Chromulan computer program.

\subsection{Statistical Analysis of Results}

The significance of differences in the size and number of stamens in the flower, mass of pollen per flower, total protein content, qualitative and quantitative composition of amino acids and fatty acids in pollen, and mineral content in the pollen grain exine was statistically analyzed using the integrated statistical and analytical package Statistica 6.0. One-way analyses of variance (ANOVA) and Tukey's multiple comparison tests were performed. Statistical inference was made at the significance level $\alpha=0.05$

\section{Results}

The stamens in the flowers of the analyzed Rubus idaeus cultivars were located along the margin of a discoid receptacle (Figure 3A,D). The anthers and filaments were white. The first pollen-releasing anthers were observed at the white bud burst stage. This process progressed from the outer to inner whorl during the subsequent stages of flower development. 

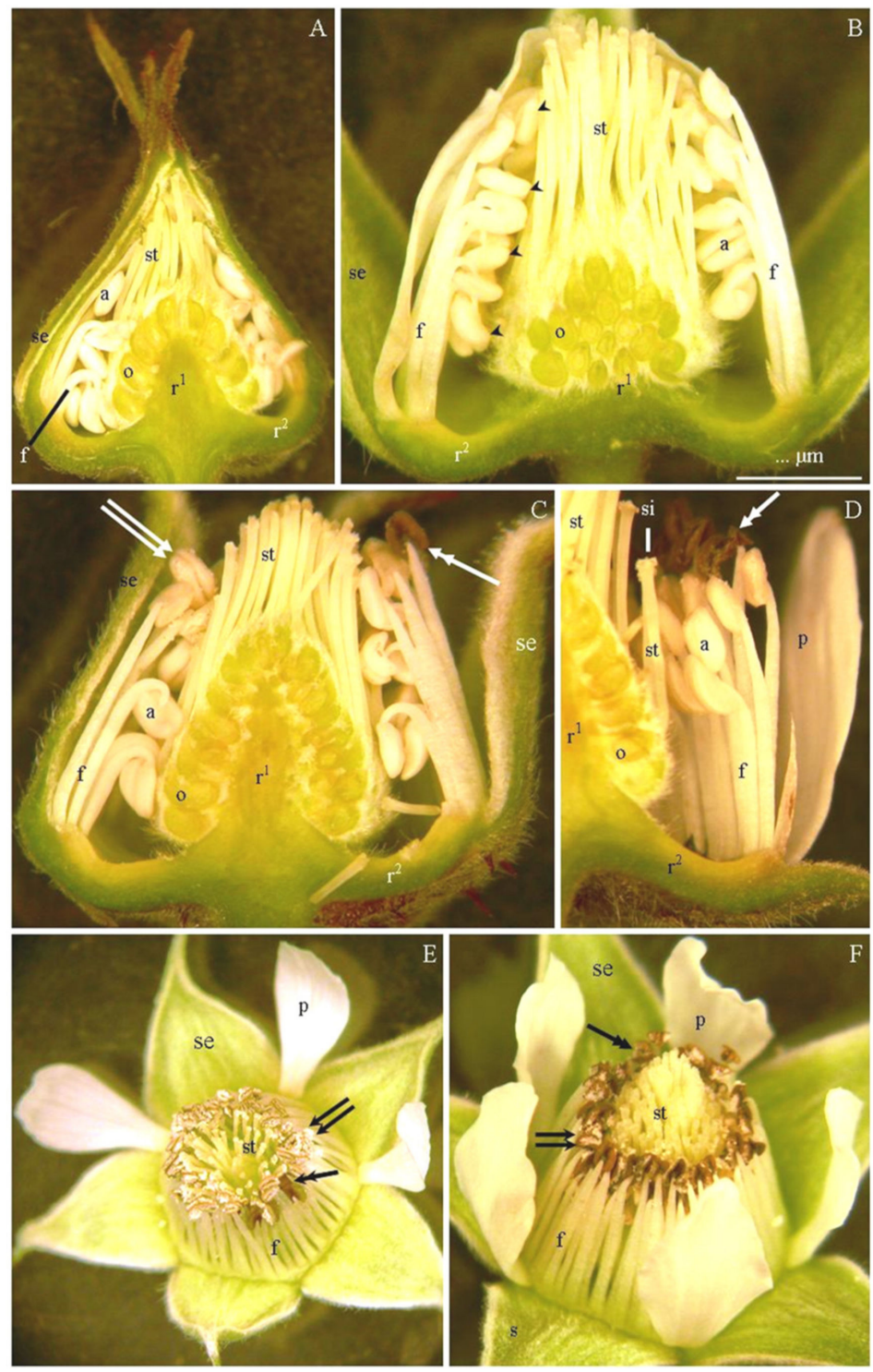

Figure 3. (A-F). Stamens and other floral elements at different stages of flower development (A-D): 'Glen Ample' (A), 'Laszka' (B), 'Radziejowa' (C), 'Polka' (D), 'Polana' (E), and 'Pokusa' (F): (A) - tightly arranged stamens at the closed-bud stage with folded filaments (f) and closed anthers (a) arranged around the ovary (o); long pistil styles (st), sepals (se), convex $\left(\mathrm{r}^{1}\right)$ and concave $\left(\mathrm{r}^{2}\right)$ receptacle, $(\mathbf{B})$ - white opening bud, closed stamen anthers $(\mathrm{a})$, straightened filaments $(\mathrm{f})$ located along the margin of the concave receptacle $\left(r^{2}\right)$, numerous ovaries (o) with long styles (st) on the convex receptacle $\left(r^{1}\right),(\mathbf{C}, \mathbf{D})$ - onset of pollen release (double-headed arrow) at the initial flowering stage of the flower; stamens with filaments (f) straightened in the outer whorl and folded in the inner whorl and with closed anthers (a) in the pollen release phase (two arrows) or in the post-pollen release phase (double-headed arrow), sepals (se), convex $\left(\mathrm{r}^{1}\right)$ and concave $\left(\mathrm{r}^{2}\right)$ receptacle, $(\mathbf{E}, \mathbf{F})$ - dehiscent anthers (two arrows) in the flower at the initial flowering stage (E) and after pollen release (double-headed arrow) at the full bloom stage (F), straightened filaments (f) surrounding the pistil style (st), corolla petals (p), and sepals (se).

\subsection{Number and Length of Stamens}

Closed anthers were observed at the closed-bud stage (Figure 3A). A few dehiscent anthers were sometimes visible at the initial bud burst stage (Figure 4B). The anthers of stamens located in the outer whorl were the first to release pollen. At the onset of flowering, most anthers exhibited dehiscent stomia (Figure 3C,D). At the full flowering stage, all stamen anthers were dehiscent (Figure 3E,F). The stamens in the flowers of the R. idaeus 
cultivars were located close to each other and formed a dense ring surrounding numerous ovaries on the convex receptacle (Figure 3A-F). Slits appeared in the apical part of the anthers after the stomium tissues ruptured at the initial stage of pollen release. Later, the cracks reached the opposite pole of the anther. The anthers had a conical shape on both poles. The connective was visible in the longitudinal recess between the elongated anthers (Figure 4A). The filament was attached in the middle of the longer axis on the adaxial side of the anther (Figure 4B).

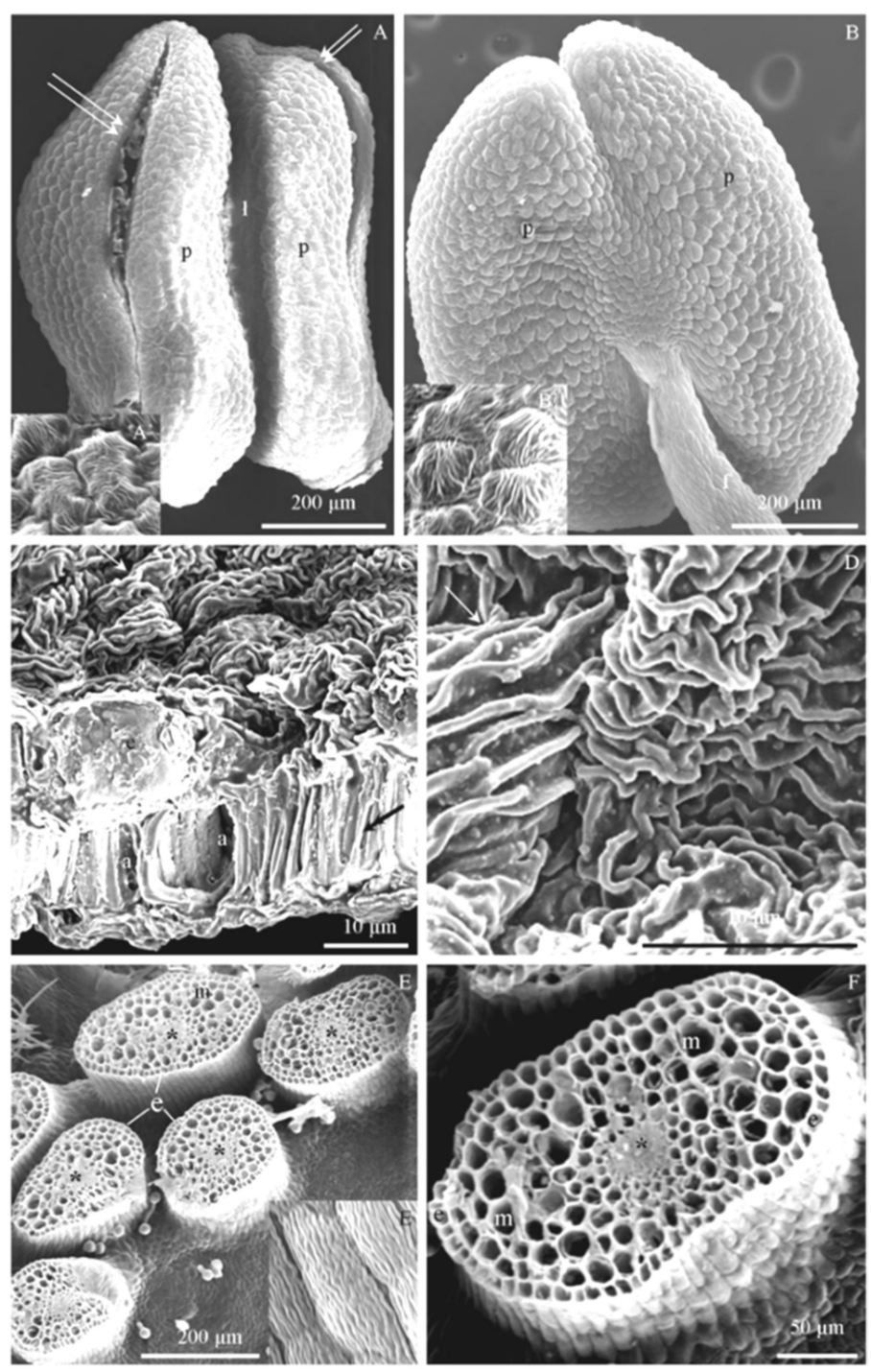

Figure 4. (A-F). Micromorphology of the epidermis (A-D) and fragments of cross-sections of stamen filaments (E,F) at the initial phase of flowering of $R$. idaeus flowers: 'Glen Ample' (A), 'Laszka' (B), 'Radziejowa' (C), 'Polka' (D), 'Pokusa' (E), and 'Polana' (F): (A)—surface of the adaxial epidermis of the anther with cracks in the dehiscent anther wall (two arrows), connective (ł) between the anthers (p), cuticle striation on the surface of epidermis cells (Figure 4A), (B)—striated surface of the abaxial anther epidermis, stamen filament (f), cuticle striation (Figure 4B), (C,D)—striation of anther epidermis cuticle-undulating multi-directionally arranged striae (arrow), longitudinal cross-section of epidermis cells (e) and endothecium (a) with visible thickening of cell walls (doubleheaded arrow) (Figure 4C), (E,F)—cross-section of a filament of stamens arranged in whorls and a striated surface of stamen filaments (Figure 4E), epidermis cells (e), parenchyma cells (m), vascular bundle (asterisk). (A-F)-SEM. 
The determination of the mean number of stamens is necessary to calculate the mass of pollen produced per flower. The mean number of stamens per flower in the $R$. idaeus biennial and repeated fruiting cultivars ranged from 98 ('Glen Ample') to 118 ('Laszka') and from 88 ('Pokusa') to 116 ('Polana'), respectively. The comparative analysis of both groups showed that the average value of this trait in 2016-2018 determined in 'Polka' was significantly lower than in 'Laszka' and 'Polana' (by 18 and 17\%, respectively) (Table 1).

The mean length of stamens in the biennial and repeated fruiting cultivars varied from 3.3 ('Laszka') to $5.0 \mathrm{~mm}$ ('Glen Ample') and from 3.5 ('Pokusa') to $4.7 \mathrm{~mm}$ ('Polka'), respectively. There were no statistically significant differences in this parameter between the individual years, between the cultivars, and between the cultivar groups (Table 2).

Table 1. Number of stamens per flower in six R. idaeus cultivars.

\begin{tabular}{|c|c|c|c|c|c|c|c|}
\hline \multirow{3}{*}{ Cultivars } & \multicolumn{7}{|c|}{ Year } \\
\hline & \multicolumn{2}{|c|}{2016} & \multicolumn{2}{|c|}{2017} & \multicolumn{2}{|c|}{2018} & \multirow{2}{*}{$\begin{array}{c}\text { Mean for } \\
\text { 2016-2018 }\end{array}$} \\
\hline & Min.-Max. & Mean & Min.-Max. & Mean & Min.-Max. & Mean & \\
\hline \multicolumn{8}{|c|}{ Biennial fruiting cultivars } \\
\hline $\begin{array}{c}\text { 'Glen } \\
\text { Ample' }\end{array}$ & 89-107 & $97.56 \pm 4.70^{\mathrm{aBC}}$ & $92-111$ & $102.38 \pm 4.69^{\mathrm{aAB}}$ & $99-125$ & $107.31 \pm 6.04^{\mathrm{aAB}}$ & $102.42 \pm 6.47^{\mathrm{AB}}$ \\
\hline 'Laszka' & $91-116$ & $109.00 \pm 6.75^{\mathrm{aAB}}$ & 97-123 & $112.56 \pm 7.77^{\mathrm{aA}}$ & $107-127$ & $117.94 \pm 6.51^{\mathrm{aA}}$ & $113.17 \pm 7.82^{\mathrm{A}}$ \\
\hline 'Radziejowa' & $92-121$ & $106.38 \pm 8.39^{\mathrm{aAB}}$ & $89-120$ & $104.63 \pm 7.75^{\mathrm{aAB}}$ & $105-122$ & $113.69 \pm 5.10^{\mathrm{aA}}$ & $108.23 \pm 8.10^{\mathrm{AB}}$ \\
\hline \multicolumn{8}{|c|}{ Repeated fruiting cultivars } \\
\hline 'Pokusa' & $75-113$ & $87.56 \pm 10.01^{b C}$ & $96-113$ & $104.75 \pm 4.89^{\mathrm{aAB}}$ & $96-110$ & $103.31 \pm 3.36^{\mathrm{aB}}$ & $98.29 \pm 10.01 \mathrm{AB}$ \\
\hline 'Polana' & $98-124$ & $111.31 \pm 7.50^{\mathrm{aA}}$ & $101-126$ & $109.63 \pm 7.16^{\mathrm{aAB}}$ & $100-123$ & $115.81 \pm 6.41^{\mathrm{aA}}$ & $112.25 \pm 7.38^{\mathrm{A}}$ \\
\hline 'Polka' & $88-97$ & $92.56 \pm 3.27^{b C}$ & 97-103 & $100.13 \pm 2.00^{\mathrm{aAB}}$ & 97-121 & $105.31 \pm 8.44^{\mathrm{aAB}}$ & $93.33 \pm 7.44^{\mathrm{B}}$ \\
\hline
\end{tabular}

Explanations: means followed by the same small letter are not significantly different within the cultivar throughout the years and means followed by the same capital letter do not differ between the cultivars in each year of the study at a significance level $\alpha=0.05$; SD-standard deviation (number of repetitions in each year $n=16$ ).

Table 2. Length of stamens per flower in six R. idaeus cultivars (mm).

\begin{tabular}{|c|c|c|c|c|c|c|c|}
\hline \multirow{3}{*}{ Cultivars } & \multicolumn{7}{|c|}{ Year } \\
\hline & \multicolumn{2}{|c|}{2016} & \multicolumn{2}{|c|}{2017} & \multicolumn{2}{|c|}{2018} & \multirow{2}{*}{$\begin{array}{l}\text { Mean for } \\
2016-2018\end{array}$} \\
\hline & Min.-Max. & Mean & Min.-Max. & Mean & Min.-Max. & Mean & \\
\hline \multicolumn{8}{|c|}{ Biennial fruiting cultivars } \\
\hline $\begin{array}{c}\text { 'Glen } \\
\text { Ample' }\end{array}$ & $4-6$ & $4.97 \pm 0.67^{\mathrm{aA}}$ & $3-6$ & $4.53 \pm 0.69^{\mathrm{aA}}$ & $3-6$ & $4.77 \pm 0.77^{\mathrm{aA}}$ & $4.76 \pm 0.73^{\mathrm{A}}$ \\
\hline 'Laszka' & $2-6$ & $3.64 \pm 0.79 \mathrm{aA}$ & $2-5$ & $3.27 \pm 0.62^{\mathrm{aA}}$ & $2-5$ & $3.92 \pm 0.78^{\mathrm{aA}}$ & $3.5 \pm 0.89^{\mathrm{A}}$ \\
\hline ‘Radziejowa' & $2-6$ & $3.86 \pm 0.72^{\mathrm{aA}}$ & $2-5$ & $3.39 \pm 0.79$ aA & $2-6$ & $3.97 \pm 0.73^{\mathrm{aA}}$ & $3.65 \pm 0.89^{\mathrm{A}}$ \\
\hline \multicolumn{8}{|c|}{ Repeated fruiting cultivars } \\
\hline 'Pokusa' & $2-6$ & $3.89 \pm 0.75^{\mathrm{aA}}$ & $2-5$ & $3.50 \pm 0.66^{\mathrm{aA}}$ & $3-6$ & $4.47 \pm 0.82^{\mathrm{aA}}$ & $3.92 \pm 0.75^{\mathrm{A}}$ \\
\hline 'Polana' & $2-5$ & $3.83 \pm 0.67^{\mathrm{aA}}$ & $2-5$ & $3.69 \pm 0.64^{\mathrm{aA}}$ & $2-5$ & $3.68 \pm 0.75^{\mathrm{aA}}$ & $3.73 \pm 0.73^{\mathrm{A}}$ \\
\hline 'Polka' & $2-5$ & $3.78 \pm 0.63^{\mathrm{aA}}$ & $2-5$ & $4.04 \pm 0.61^{\mathrm{aA}}$ & $3-7$ & $4.67 \pm 0.66^{\mathrm{aA}}$ & $4.06 \pm 0.72^{\mathrm{A}}$ \\
\hline
\end{tabular}

Explanations: means followed by the same small letter are not significantly different within the cultivar throughout the years and means followed by the same capital letter do not differ between the cultivars in each year of the study at a significance level $\alpha=0.05$; SD—standard deviation (number of repetitions in each year $n=30$ ).

\subsection{Micromorphology of Stamen Epidermis}

Anther. Striated cuticular ornamentation was observed on the epidermis surface on both anther sides (Figure 4A,B). The striae exhibited dense parallel arrangement in various directions and were strongly undulating. The striae were curved and had arcuate, semicircular, or loop-like shapes. These structures sometimes overlapped (Figure 4C,D).

Filament. The cuticle ornamentation on the stamen epidermis surface was formed by striae arranged in parallel with slight undulations. These structures were tightly arranged 
towards the longer axis of the cells. They had a corrugated shape with a slight arcuate curvature with alternate arrangement (Figure 4E).

\subsection{Anatomy of Stamens}

Filament. In cross-section, the basal part of the filaments was ellipsoidal, spherical, or slightly flattened. Consequently, they were slightly elongated towards the adjacent stamens in the whorl. The anther epidermis cells were smaller than the neighboring parenchyma cells. The latter were arranged concentrically, forming 4-7 layers around a centrally located vascular bundle (Figure 4E,F).

Anther. At the white bud burst stage, the cross-section of the anthers showed that the outer epidermal cell wall was thicker than the other epidermal cell walls (Figure 5A,B). The outer wall of the epidermal cells formed elevations covered by a cuticle layer corresponding to the cuticle striae. The epidermis and endothecium cells were vacuolated (Figure 5B-E).

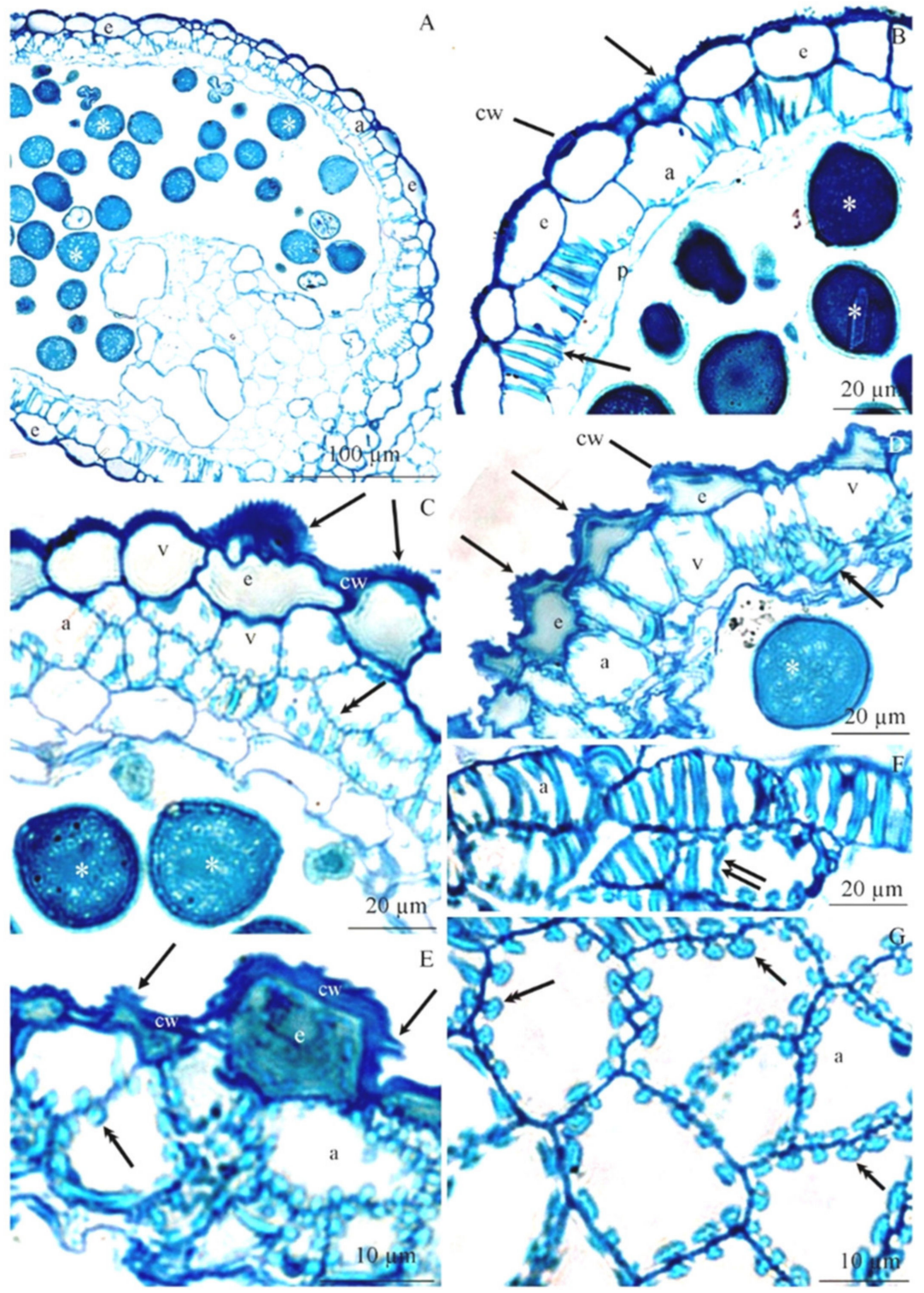

Figure 5. (A-G). Fragments of transverse and longitudinal sections of anthers at the white bud 
burst stage in R. idaeus 'Glen Ample' (A), 'Laszka' (B), 'Radziejowa' (D), 'Polana' (E), 'Polka' (F), and 'Pokusa' (G): (A) — epidermis cells (e), endothecium cells (a), visible pollen grains (asterisk), (B) -thick outer cell wall (cw) of the epidermis (e), cuticle striae (arrow), endothecium cells (a), ledge-shaped wall thickenings (double-headed arrow), middle layer cells (p), pollen grains (asterisk), (C), (D)-outer cell wall (cw) of the epidermis with numerous evaginations (arrows), large vacuole $(\mathrm{v})$, thickening of endothecium walls (double-headed arrow), pollen grains (asterisk), (E) - evaginations (arrows) of the epidermis (e) cell wall (cw), thickening of endothecium (a) cell walls (double-headed arrow), (F,G) — thickenings of cell walls in the form of parallel ledges (two arrows) - longitudinal section (Figure 5F), regularly arranged semicircular evaginations (arrowheads)—cross-section (Figure 5G). (A-G)-LM .

The endothecium cells were much larger than the epidermis cells. The endothecium cell wall exhibited ledge-shaped thickenings in the longitudinal section (Figures $4 \mathrm{C}$ and $5 \mathrm{~B}, \mathrm{~F}$ ) or regularly arranged semicircular evaginations visible in the cross-section (Figure $5 \mathrm{C}-\mathrm{E}, \mathrm{G}$ ). The thickenings were regularly located on both sides of the anticlinal and periclinal walls. Pollen grains were visible in the anthers (Figure 5A-D).

\subsection{Ultrastructure of Anther Cells}

Epidermis. The cross-section of the anther epidermis cells showed a strongly thickened outer cell wall. These cells had a parietal cytoplasm and a large vacuole (Figure 6A-C). The cytoplasm contained numerous mitochondria, plastoglobules, and sometimes pleomorphic plastids (Figure 6D). The surface of the outer periclinal cell wall was undulating. The wall formed evaginations of various shapes and sizes. They were arranged perpendicular to the anther surface (Figure 6B,D-G) or obliquely near the anticlinal walls of adjacent cells (Figure 6B,C). The cuticle layer was distributed homogeneously on the epidermis surface (Figure 6B-H). The lamellar cuticle proper and the outer and inner layers of reticulate cuticle were observed in this multifunctional part of the cell wall (Figure 6E-H).

Endothecium. The endothecium cells were substantially larger than the epidermis cells (Figure 6A). In the cross-section, the periclinal and anticlinal walls of the endothecium exhibited characteristic thickenings corresponding to the strengthening ledges visible in their longitudinal section (Figures 6A and 7A-D). The evaginations of the walls of adjacent cells were regular on both sides. They were perpendicular to the wall, vesicular, and tapered at the base. They were arranged in series in one cell and oppositely or alternately in adjacent cells (Figure 7C,D).

\subsection{The Mass of Pollen Produced}

Pollen and nectar from the flowers of the analyzed $R$. idaeus cultivars were collected mainly by honeybees and bumblebees. The mass of pollen produced by one stamen was converted into a value per 100 stamens and per flower. In 2016-2018, the mean mass of pollen from 10 flowers of the biennial fruiting cultivars and the repeated fruiting cultivars ranged from 24.8 ('Glen Ample') to $35.7 \mathrm{mg}$ ('Laszka') and from 22.5 ('Pokusa') to 26.3 $\mathrm{mg}$ ('Polka'), respectively. In the first group of cultivars, the pollen mass in 'Laszka' was substantially higher than in 'Radziejowa', whereas lower values were recorded in 'Glen Ample' in comparison with the latter cultivar. The value of this parameter in the cultivars from the second group, i.e., 'Polana' and 'Polka', was comparable to the pollen mass in 'Radziejowa' from the first group but considerably exceeded the mass of pollen produced by 'Pokusa'. In terms of the differences between the pollen mass of each cultivar in the individual years, it was shown that the pollen mass 'Radziejowa' and 'Laszka' in 2017 was significantly higher compared to the values noted in 2016 and 2018. In 'Glen Ample', it was lower in 2018 than in 2016-2017. Moreover, in 2018, the pollen mass in 'Pokusa' and 'Polka' was clearly higher than in 2016-2017, whereas the value of this parameter in 'Polana' in 2016 markedly exceeded the values recorded in 2017-2018. In terms of the differences between the cultivars in 2016, it was found that 'Laszka' and 'Polka' were characterized by significantly higher pollen mass than the other cultivars in their groups, and a lower value of this parameter was found in 'Pokusa'. Simultaneously 'Radziejowa' produced greater 
amounts of pollen than 'Polka' and 'Glen Ample'. In 2017, the highest pollen mass was recorded in 'Laszka', and the lowest value was detected in 'Pokusa'. In turn, the parameter in 'Radziejowa' had a higher value than in 'Glen Ample', 'Polana', and 'Polka'. In 2018, 'Laszka' produced the greatest amounts of pollen, whereas 'Glen Ample' and 'Polana' were characterized by the lowest value of the parameter (Figure 8).

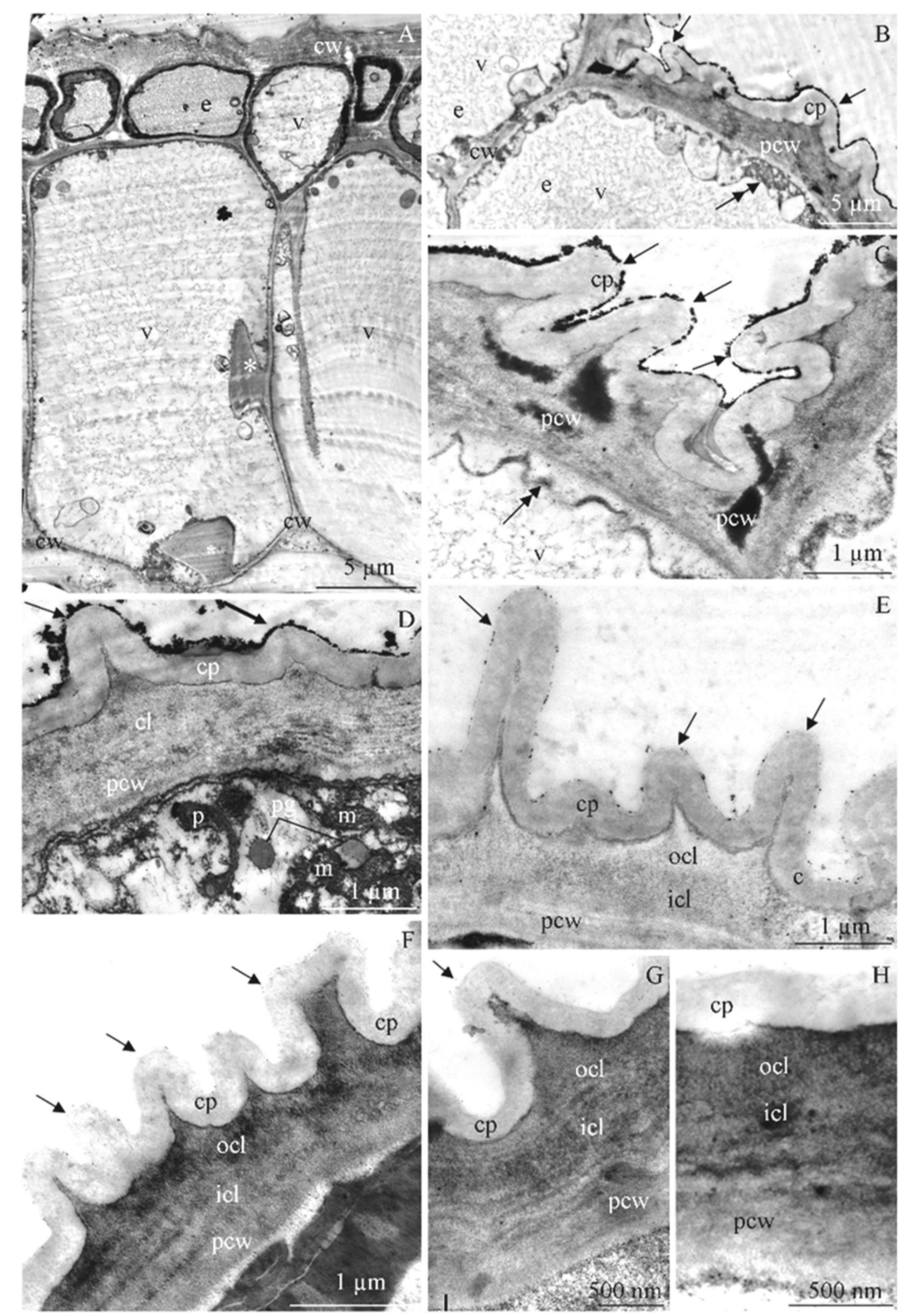

Figure 6. (A-H). Fragments of epidermis (A-H) and endothecium (A) cells in R. idaeus 'Glen Ample' (A,H), 'Laszka' (B,C), 'Radziejowa' (D), 'Polka' (E), 'Polana' (F), and 'Pokusa' (G): (A)thick outer cell wall (cw) of small vacuolated epidermis cells (e), large endothecium cells (a) with thick evaginations (asterisk) of the inner periclinal and anticlinal walls, (B,C)-epidermis cells (e), cell walls (cw), evaginations of the outer wall (arrows), cuticle proper layer (cp), the other part of the cell wall (pcw), parietal cytoplasm (double-headed arrow), vacuole (v), (D)-evaginations of the cell wall (arrow), a band of cuticle proper ( $\mathrm{cp}$ ) with homogeneous thickness and lamellar structure, reticulate cuticle layer $(\mathrm{cl})$, the other part of the cell wall (pcw), mitochondria $(\mathrm{m})$, plastoglobules (pg), amorphous plastid (p), (E-H) — evaginations of the cell wall (arrow) with varied height (E,F), visible lamellar cuticle proper (cp), outer (ocl) and inner (icl) reticulate cuticle layer, the rest of the cell wall (pcw); (A-H) - TEM. 


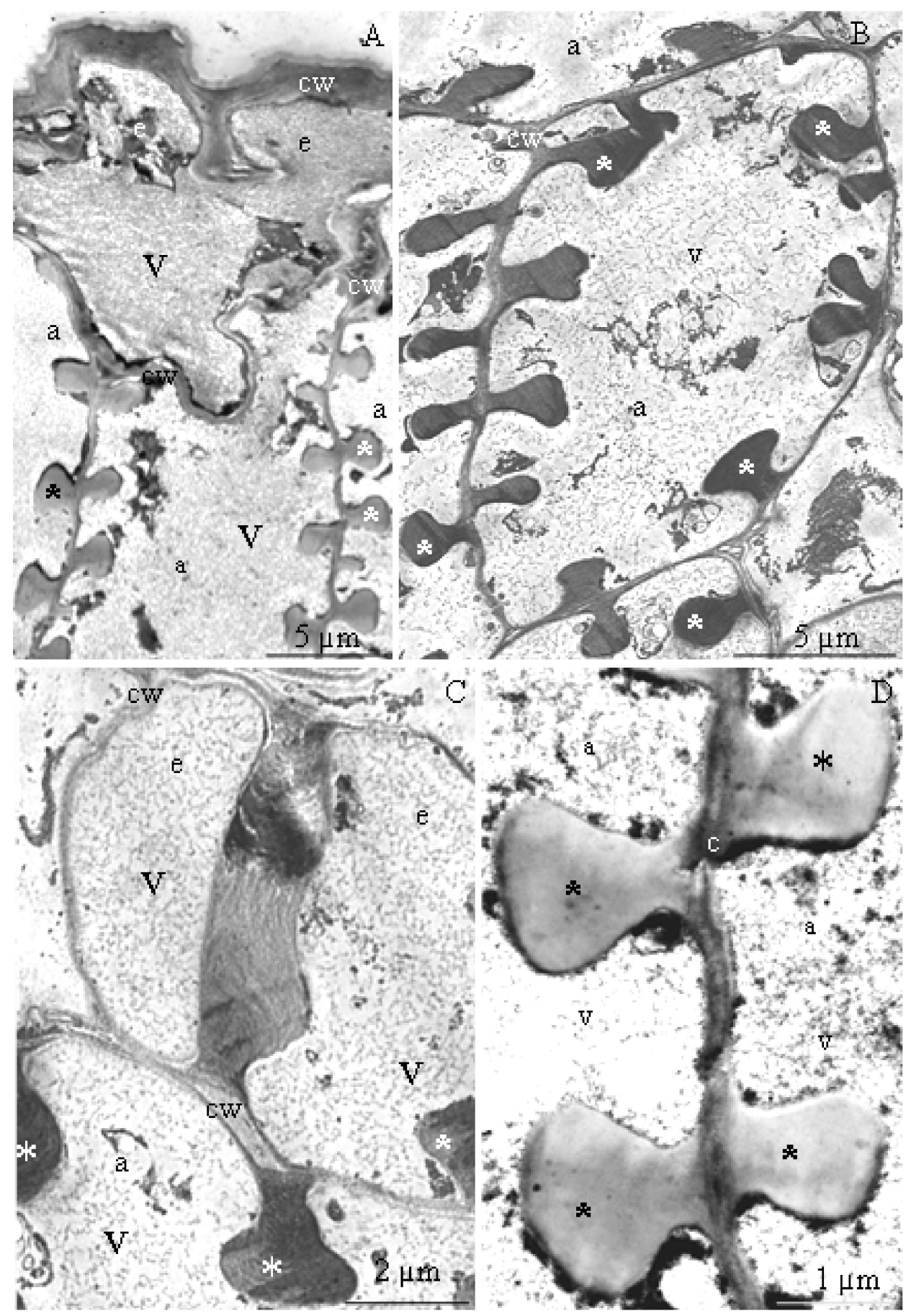

Figure 7. (A-D). Epidermis (A) and anther endothecium (A-D) cells in R. idaeus 'Glen Ample' (A), 'Laszka' (B), 'Polka' (C), 'Pokusa' (D): (A)—epidermis (e) and endothecium (a), visible thick outer epidermis cell wall (cw), regular thickenings of the endothecium cell walls (asterisks), vacuole (v), (B) - endothecium cells, visible anti- and periclinal cell walls (cw) with characteristic thickenings (asterisks), vacuole (v), (C,D)—epidermis (e) (Figure 7C) and endothecium (a) (Figure 7C,D) cells, visible thickenings (asterisk) of the endothecium cell wall (cw), vacuole (v); (A-D)—TEM. 


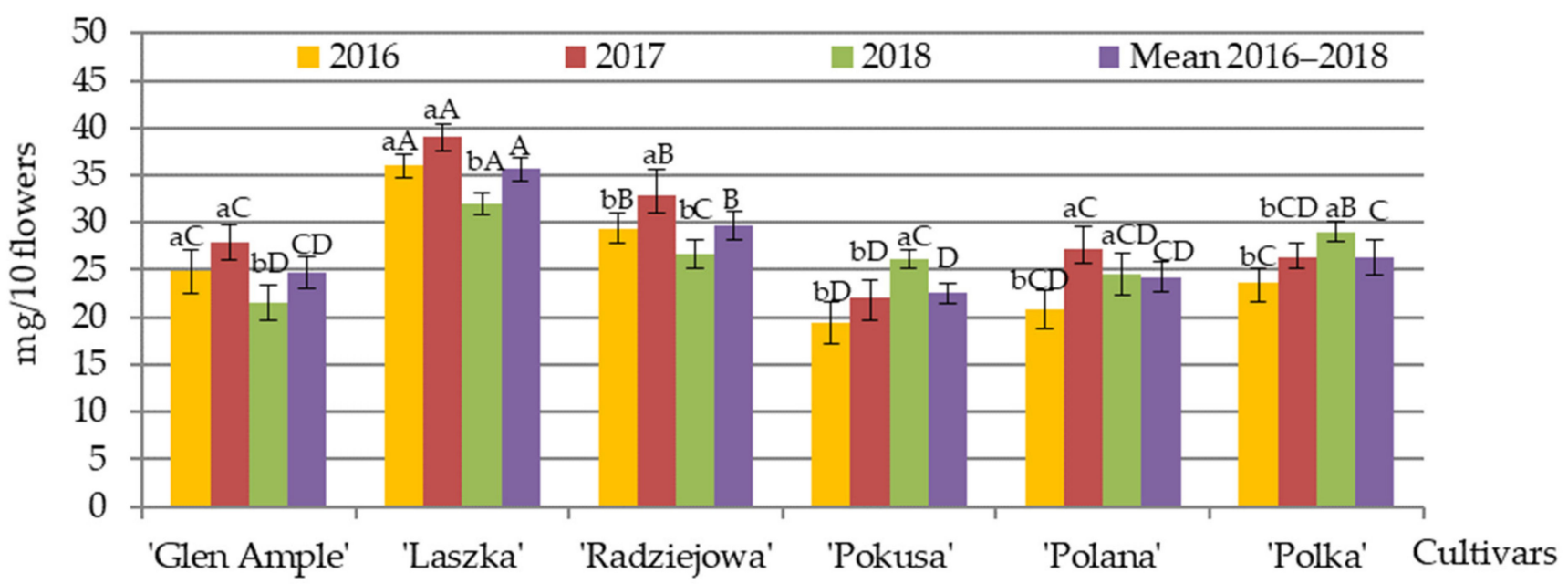

Figure 8. Mass of pollen produced by 10 flowers of $R$. idaeus cultivars. Explanations: means followed by the same small letter are not significantly different within the cultivars for the years and means followed by the same capital letter do not differ between the cultivars in each year at a significance level $\alpha=0.05$; (number of repetitions in each year $n=10$ ). Bars indicate standard deviation.

\subsection{Total Protein Content}

In 2016-2018, the mean protein content in the pollen grains of the analyzed $R$. idaeus cultivars was from 25.5 ('Glen Ample') to 33.4\% ('Laszka') in the biennial fruiting group and from 24.9 ('Polana') to 30.7\% ('Pokusa') in the repeated fruiting group. In the group of the biennial fruiting cultivars, the pollen from 'Laszka' had significantly lower protein content in 2016 than in the subsequent study years. The pollen from 'Radziejowa' was characterized by a significantly lower value in 2017 and a similar value of this parameter in 2018 , compared to that recorded in 2016. The protein content in the pollen grains from the repeated fruiting cultivars did not change statistically significantly in the subsequent years, with the exception of the significant increase in this parameter in 2017 compared to 2016. In terms of the differences between the cultivars in each study year, in 2016, a significantly higher concentration of protein was determined in the 'Radziejowa' pollen grains than in 'Glen Ample', 'Laszka', 'Polana', and 'Polka'. In turn, in 2017, a significantly higher value of this parameter was determined in 'Laszka' in comparison with 'Radziejowa' and 'Polana'. In 2018, 'Laszka' had higher pollen protein content than 'Polana' and 'Polka'. According to the mean protein content in the pollen grains in 2016-2018, the cultivars were ranked as follows: 'Polana' $(26.1 \%)<$ 'Polka' $(27.7 \%)<$ 'Glen Ample' $(28.1 \%)<$ 'Pokusa' $(29.3 \%)<$ 'Radziejowa' $(29.7 \%)<$ 'Laszka' (31.3\%). The comparative analysis of the two groups showed a significantly higher concentration of protein in the pollen of 'Laszka' than 'Polana' (Table 3).

Table 3. Percent content of total protein in pollen from six R. idaeus cultivars.

\begin{tabular}{|c|c|c|c|c|c|c|c|}
\hline \multirow{3}{*}{ Cultivars } & \multicolumn{7}{|c|}{ Study Year } \\
\hline & \multicolumn{2}{|c|}{2016} & \multicolumn{2}{|c|}{2017} & \multicolumn{2}{|c|}{2018} & \multirow{2}{*}{$\begin{array}{l}\text { Mean for } \\
2016-2018\end{array}$} \\
\hline & Min.-Max. & Mean & Min.-Max. & Mean & Min.-Max. & Mean & \\
\hline \multicolumn{8}{|c|}{ Biennial fruiting cultivars } \\
\hline $\begin{array}{c}\text { 'Glen } \\
\text { Ample' }\end{array}$ & $23.43-28.13$ & $25.53 \pm 2.39 \mathrm{aB}$ & $26.37-31.97$ & $29.45 \pm 2.97 \mathrm{aAB}$ & $26.08-32.16$ & $28.96 \pm 3.05^{\mathrm{aAB}}$ & $28.08 \pm 3.12 \mathrm{AB}$ \\
\hline 'Laszka' & $26.13-29.87$ & $27.94 \pm 1.87^{\mathrm{bB}}$ & $30.05-33.84$ & $32.27 \pm 1.98^{\mathrm{aA}}$ & $30.71-35.91$ & $33.67 \pm 2.67^{\mathrm{aA}}$ & $31.29 \pm 3.21^{\mathrm{A}}$ \\
\hline ‘Radziejowa’ & $29.86-32.63$ & $31.27 \pm 1.39 \mathrm{aA}$ & $26.02-28.35$ & $27.43 \pm 1.24^{\mathrm{bBC}}$ & $27.81-32.91$ & $30.49 \pm 2.56^{\mathrm{abAB}}$ & $29.73 \pm 2.36^{\mathrm{AB}}$ \\
\hline
\end{tabular}


Table 3. Cont.

\begin{tabular}{|c|c|c|c|c|c|c|c|}
\hline \multirow{3}{*}{ Cultivars } & \multicolumn{7}{|c|}{ Study Year } \\
\hline & \multicolumn{2}{|c|}{2016} & \multicolumn{2}{|c|}{2017} & \multicolumn{2}{|c|}{2018} & \multirow{2}{*}{$\begin{array}{l}\text { Mean for } \\
2016-2018\end{array}$} \\
\hline & Min.-Max. & Mean & Min.-Max. & Mean & Min.-Max. & Mean & \\
\hline \multicolumn{8}{|c|}{ Repeated fruiting cultivars } \\
\hline 'Pokusa' & 25.89-29.91 & $27.90 \pm 2.01 \mathrm{aAB}$ & $27.31-33.92$ & $30.65 \pm 3.31^{\mathrm{aAB}}$ & $26.04-31.34$ & $29.45 \pm 2.96^{\mathrm{aAB}}$ & $29.34 \pm 2.71 \mathrm{AB}$ \\
\hline 'Polana' & $23.53-26.93$ & $24.93 \pm 1.78^{\mathrm{aB}}$ & $25.31-27.08$ & $26.13 \pm 0.89 \mathrm{aC}$ & $26.31-28.02$ & $27.32 \pm 0.90^{\mathrm{aB}}$ & $26.13 \pm 1.67^{\mathrm{B}}$ \\
\hline 'Polka' & $25.42-27.03$ & $26.46 \pm 0.90^{\mathrm{bB}}$ & $27.92-31.51$ & $29.58 \pm 1.81^{\mathrm{aA}}$ & $24.96-28.32$ & $27.05 \pm 1.82^{\mathrm{abB}}$ & $27.70 \pm 1.98^{\mathrm{AB}}$ \\
\hline
\end{tabular}

Explanations: means followed by the same small letter are not significantly different within the cultivar throughout the years and means followed by the same capital letter do not differ between the cultivars in each year of the study at a significance level $\alpha=0.05$; SD-standard deviation (number of repetitions in each year $n=3$ ).

\subsection{Qualitative and Quantitative Amino Acid Composition}

The pollen of the $R$. idaeus cultivars contained 15 amino acids: six exogenous amino acids (phenylalanine, isoleucine, leucine, lysine, threonine, and valine) and nine endogenous amino acids (alanine, arginine, glycine, histidine, aspartic acid, glutamic acid, proline, serine, and tyrosine).

Exogenous amino acids. The mean percentage proportion of exogenous amino acids in the total amino acid content in the pollen of the $R$. idaeus cultivars ranged from 32.7 ('Polka') to 38.8\% ('Radziejowa'). Leucine, lysine, and valine dominated in all examined cultivars. Leucine, isoleucine, and valine represent the branched-chain amino acid (BCAA) complex. The mean content of leucine, isoleucine, and valine $\left(\mathrm{mg} \cdot \mathrm{g}^{-1}\right)$ in the pollen analyzed in 2016-2018 ranged as follows: 22 ('Glen Ample') -33.6 ('Radziejowa'), 17 ('Glen Ample')—21.5 ('Laszka'), and 21.5 ('Glen Ample')—25 ('Laszka') in the group of the biennial fruiting and 25.5 ('Polka') —27.5 ('Pokusa'), 15 ('Polana') —19 ('Polka'), and 18 ('Polana')—22 ('Polka') in the repeated fruiting cultivars, respectively (Figure 9A-F).

The mean leucine content was significantly higher in the 'Radziejowa' pollen than in the other cultivars and substantially higher in 'Pokusa' than in 'Glen Ample'. Generally, the level of this amino acid in 'Glen Ample', 'Laszka', and 'Polka' was markedly lower in 2017 and 2018 than in 2016. In turn, no clear differences in the value of this parameter were found for the other cultivars during the consecutive study years (Figure 9A).

The average content of isoleucine in 'Laszka' was comparable to that found in 'Radziejowa' and significantly higher than in the other cultivars. Its amount in 'Radziejowa', 'Glen Ample', Pokusa', and 'Polka' significantly exceeded the levels detected in 'Polana'. The content of this amino acid in 'Glen Ample', 'Laszka', 'Polka', and 'Pokusa' was markedly higher in 2017 and 2018 than in 2016. The comparison of the differences between the cultivars in the study years revealed a significantly higher level of isoleucine in 'Laszka' and 'Radziejowa' than in the other cultivars in 2016. In turn, in 2017 and 2018, its content was clearly higher in 'Laszka' than in the other cultivars, whereas 'Polana' was characterized by substantially lower levels of this amino acid in comparison with 'Glen Ample', 'Radziejowa', 'Pokusa', and 'Polka' (Figure 9B).

The pollen of 'Laszka' had significantly higher valine content than 'Glen Ample', 'Pokusa', 'Polka', and 'Polana', with the lowest amount of this amino acid in 'Polana'. A markedly lower valine amount was determined in the pollen from 'Laszka', 'Pokusa', and 'Polka' in 2016 than in 2017 and 2018. The comparison of this amino acid content between the study years demonstrated its lower level in the second year in 'Radziejowa' and 'Polana'. In terms of the differences between the cultivars in the individual years, the valine concentration was higher in 'Laszka' and 'Radziejowa' than in the other cultivars. Furthermore, its content in 'Polana' was significantly lower than in 'Pokusa', 'Polka', and 'Glen Ample' (Figure 9C). 

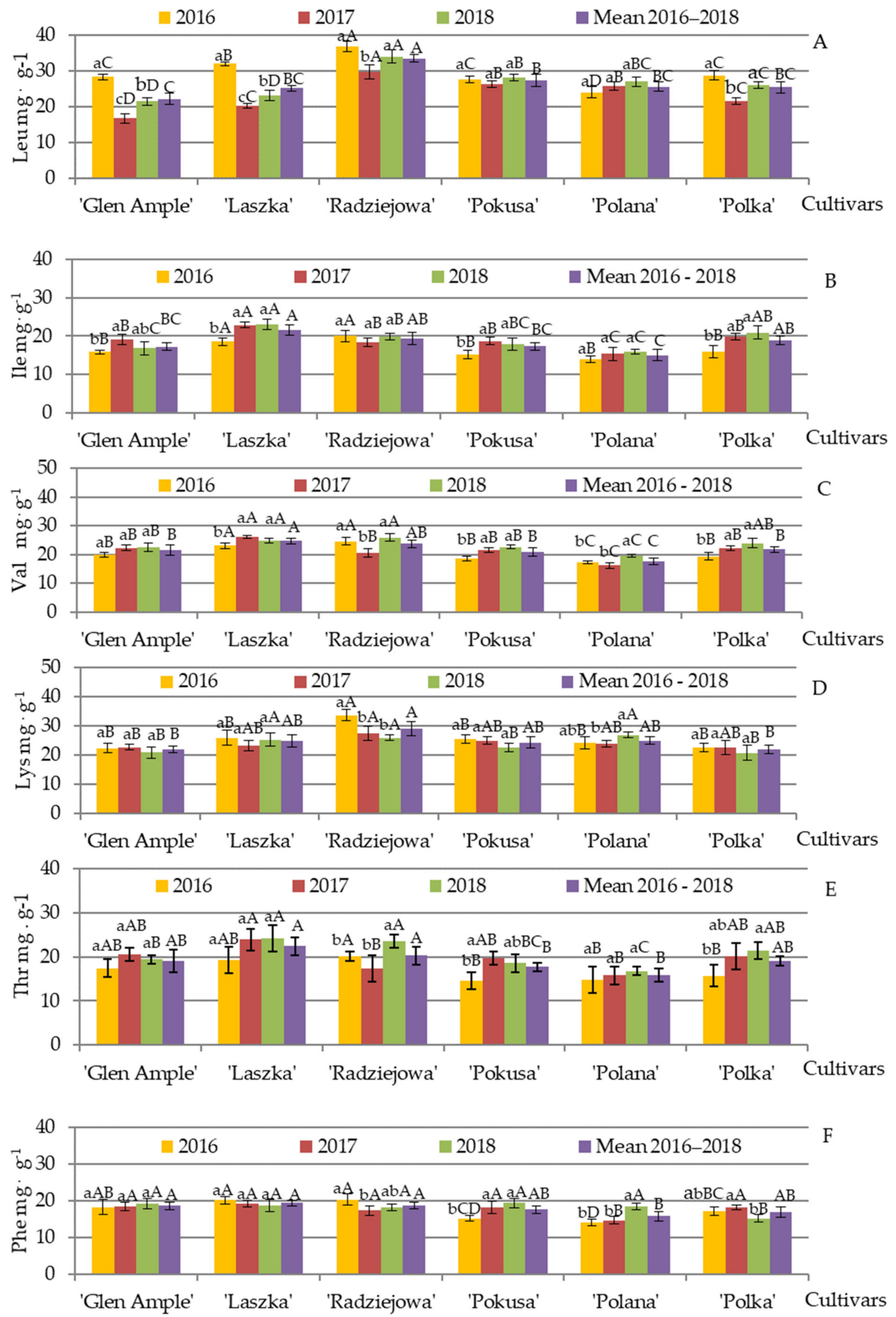

Figure 9. (A-F). Content of exogenous amino acids in the pollen of R. idaeus cultivars. For explanations, see Figure 8 (number of repetitions in each year $\mathrm{n}=3$ ). 
The mean content of lysine, threonine, and phenylalanine $\left(\mathrm{mg} \cdot \mathrm{g}^{-1}\right)$ in the pollen of the biennial fruiting cultivars analyzed in 2016-2018 was in the following range: 22 ('Glen Ample') —29 ('Radziejowa'), 19.0 ('Glen Ample')—22.5 ('Laszka'), and 18.6 ('Glen Ample')— 19.4 ('Laszka'), respectively. The levels of these amino acids $\left(\mathrm{mg} \cdot \mathrm{g}^{-1}\right)$ in the repeated fruiting cultivars were in the range of 22 ('Polka') -25 ('Polana'), 16.0 ('Polana')-19.0 ('Polka'), and 15.8 ('Polana')—17.6 ('Pokusa'), respectively (Figure 9D-F).

A significantly lower level of lysine was detected in the pollen from 'Glen Ample' and 'Polka' than from 'Radziejowa'. The content of this amino acid declined substantially in 'Radziejowa' in 2017 and 2018, compared with 2016, and increased markedly in the 'Polana' cultivar between 2017 and 2018. The comparative analysis between the cultivars in the individual years showed significantly higher lysine content in 'Radziejowa' in 2016, whereas significant differences were found in 2017-2018 only between 'Radziejowa' and 'Glen Ample' (Figure 9D).

The pollen from the 'Laszka' contained a significantly higher amount of threonine than 'Pokusa' and 'Polana'. Its content in 'Radziejowa' was substantially higher in 2018 than in 2016 and 2017. 'Pokusa' had a significantly lower level of threonine in 2016 than in 2017, and 'Polka' was characterized by a clearly higher amount of this amino acid in 2018 than in 2016. The analysis of the differences between the cultivars in the individual study years showed substantially higher threonine content in 'Radziejowa' than in the repeated fruiting cultivars in 2016, whereas the level of this amino acid in 2017 was markedly higher in 'Laszka' than in 'Radziejowa' and 'Polana'. In turn, in 2018, its content was significantly higher in 'Laszka' than in 'Glen Ample', 'Pokusa', and 'Polana'. Simultaneously, the threonine level in 'Polana' was significantly lower than in 'Glen Ample' (Figure 9E).

The pollen from 'Polana' contained significantly lower mean amounts (2016-2018) of phenylalanine than the biennial fruiting cultivars. In 2018, its level was significantly higher in 'Polana' and lower in 'Polka' compared to the previous year. The content of this amino acid in 'Pokusa' in 2016 was evidently below the amounts recorded in 2017 and 2018. In 2016, the phenylalanine content in the biennial fruiting cultivars markedly exceeded the values recorded for the repeated fruiting cultivars, with its evidently higher level in 'Polka' than 'Pokusa' and 'Polana'. In 2017 and 2018, there were no distinct differences in the phenylalanine content between the studied cultivars, except the lower amount of this amino acid in 'Polana' in 2017 and 'Polka' in 2018 (Figure 9F).

Endogenous amino acids. Aspartic acid, proline, and glutamic acid were the dominant endogenous amino acids in the pollen of the studied $R$. idaeus cultivars; considerable amounts of alanine, serine, and arginine were detected as well. The mean content of aspartic acid, proline, and alanine $\left(\mathrm{mg} \cdot \mathrm{g}^{-1}\right)$ in the pollen analyzed in 2016-2018 was in the range of 44.6 ('Glen Ample')—51.5 ('Radziejowa'), 24.9 ('Radziejowa') —28.7 ('Laszka'), and 24.2 ('Glen Ample')-26.7 ('Laszka'), respectively, in the biennial fruiting cultivars. In turn, their content in the repeated fruiting cultivars $\left(\mathrm{mg} \cdot \mathrm{g}^{-1}\right)$ was in the following range: 43.5 ('Polana') —44.2 ('Polka'), 22.8 ('Polana')—33 ('Polka'), and 22.36 ('Polana')—24.9 ('Pokusa'), respectively (Figure $10 \mathrm{~A}-\mathrm{C}$ ). 

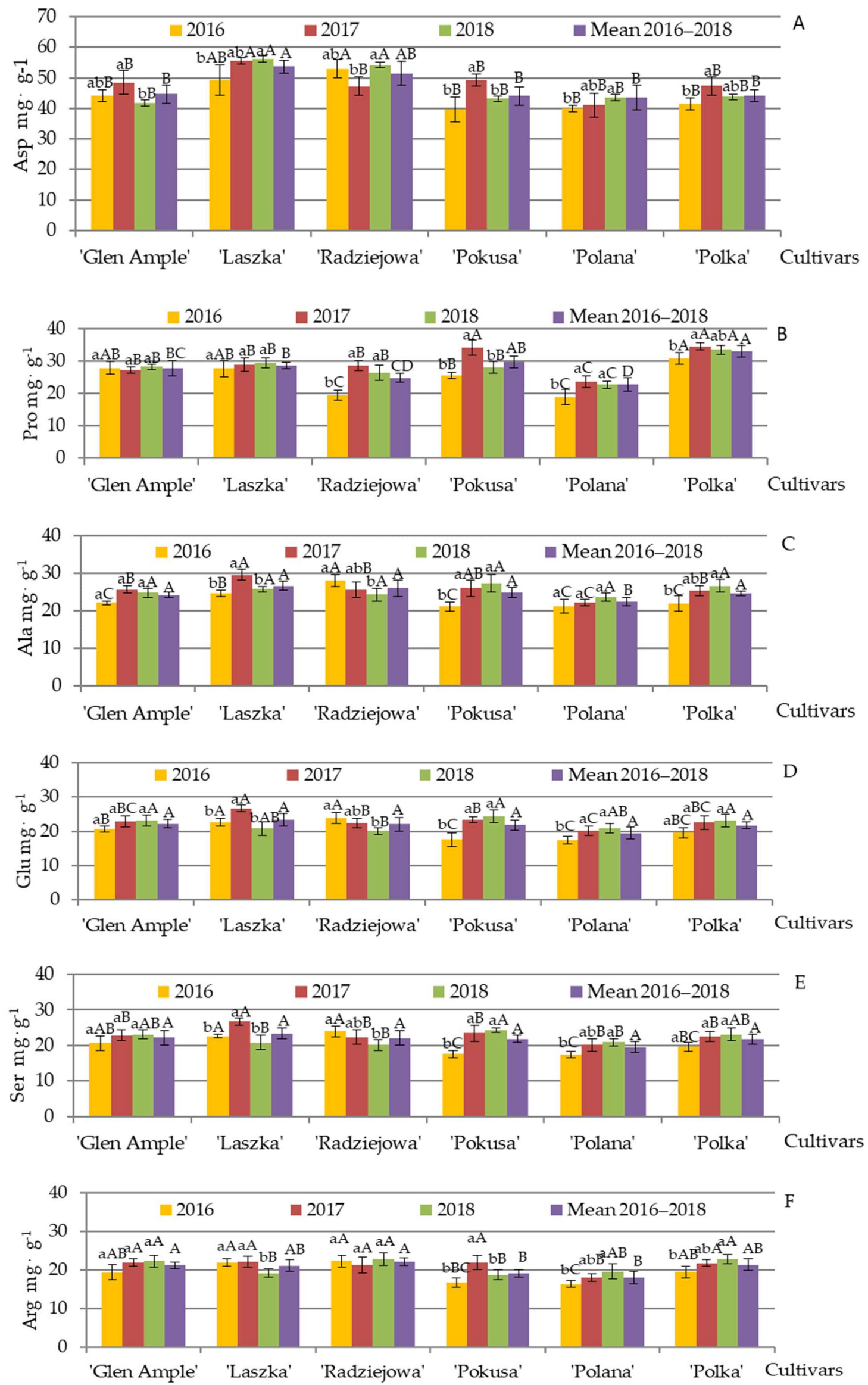

Figure 10. Cont. 

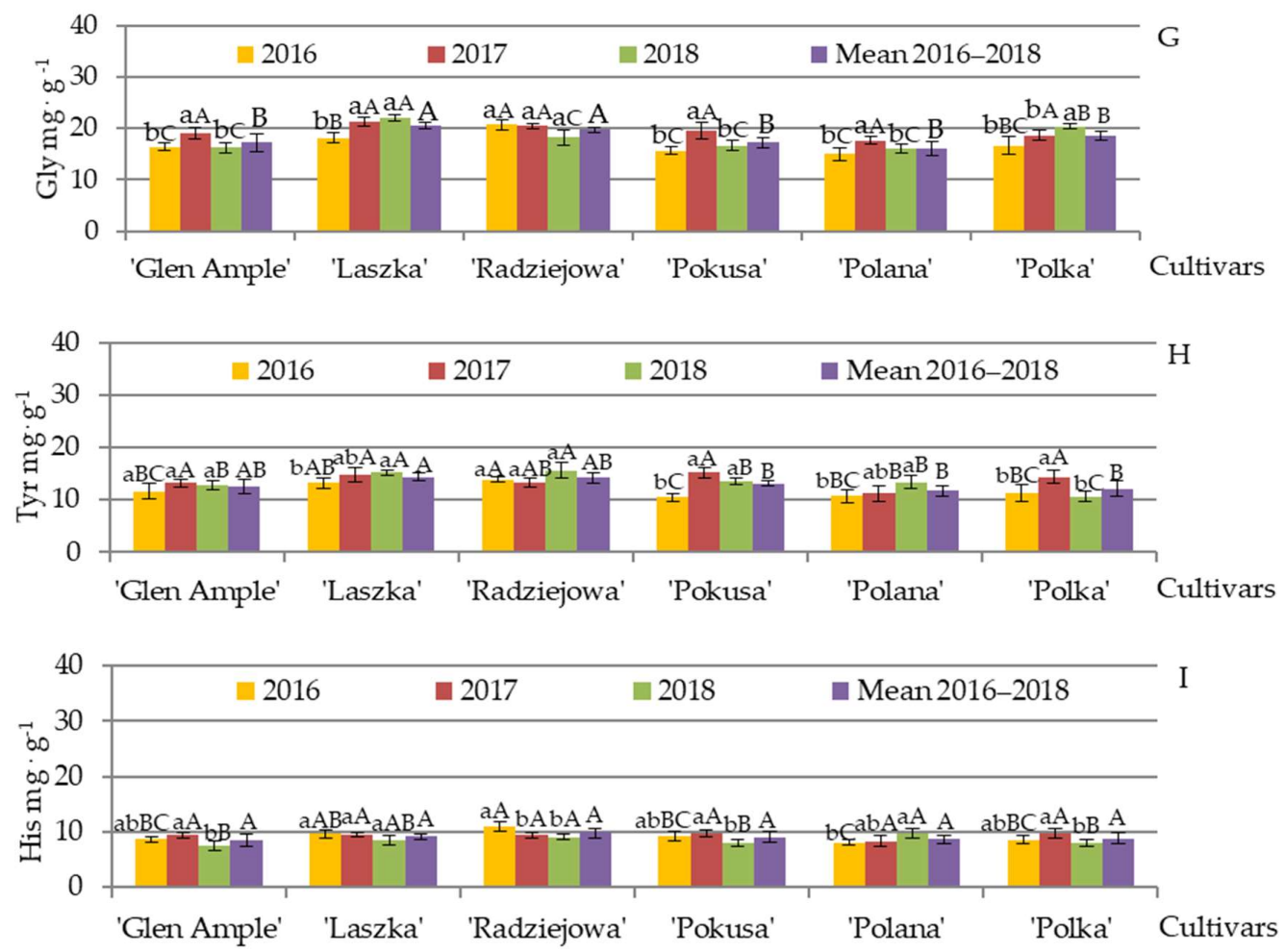

Figure 10. (A-I). Content of endogenous amino acids in the pollen of R. idaeus cultivars. For explanations, see Figure 8 (number of repetitions in each year $\mathrm{n}=3$ ).

The average aspartic acid level in 'Laszka' was higher than the amounts noted for the other cultivars, whereas its content in 'Radziejowa' was comparable to the other values of the parameter. The aspartic acid content in the pollen of 'Glen Ample' was significantly higher in 2017 than in 2018. In 'Laszka' and 'Polana', it was markedly lower in 2016 than in 2018. In turn, 'Radziejowa' exhibited considerably lower levels, whereas 'Pokusa' and 'Polka' had higher content of this amino acid in 2017 than in 2016 and 2018. The comparative analysis between the cultivars showed that the aspartic acid content in 'Laszka' and 'Radziejowa' in 2016 and 2018 did not differ significantly but was substantially higher than in the other cultivars. In turn, the highest amount of this amino acid in 2017 was detected in 'Laszka' (Figure 10A). The level of proline was significantly higher in the pollen of 'Polka' than 'Radziejowa' and 'Polana' and lower than in the other cultivars. In 2016, its content in 'Radziejowa', 'Polana', and 'Polka' was much lower than in 2017-2018. In 'Pokusa' in 2017, it was clearly below the values recorded in 2016 and 2018.

The level of proline was significantly higher in the pollen of 'Polka' than 'Radziejowa' and 'Polana' and lower than in the other cultivars. In 2016, its content in 'Radziejowa', 'Polana', and 'Polka' was much lower than in 2017-2018. In 'Pokusa' in 2017, it was clearly above the values recorded in 2016 and 2018. The analysis of the differences between the cultivars in 2016 showed that the proline content in 'Radziejowa' and 'Polana' was lower than in the other cultivars. Moreover, the level of this amino acid in 'Polka' was significantly higher than in 'Pokusa', and comparable to that in 'Glen Ample' and 'Laszka'. It was also found that the proline concentration in the pollen of the biennial fruiting cultivars in 2017 was clearly lower than in 'Pokusa' and 'Polka', but higher than in 'Polana'. In turn, in the last year of the experiment, 'Polka' was characterized by a higher level, whereas 'Polana' exhibited a lower amount of this amino acid than the other examined cultivars (Figure 10B).

The average alanine level in the 'Polana' pollen was significantly lower than in the other cultivars. Its concentration in 'Laszka' in 2017 was clearly higher than in 2016 and 2018; it was lower in 'Pokusa' and 'Polka' in 2016 than in 2017-2018, and significantly 
lower in 'Radziejowa' in 2018 than in 2016-1017. The comparative analysis between the cultivars in the first year of the experiment showed distinctly lower alanine content in 'Laszka' than in 'Radziejowa', but greater amounts than in the other cultivars. In the second year of the studies, the amounts of this amino acid detected in the pollen of 'Glen Ample', 'Radziejowa', 'Polka', and 'Pokusa were substantially lower than in 'Laszka' but higher than in 'Polana'. In turn, in the last year of the experiment, there were no significant differences in the alanine level between the analyzed cultivars (Figure 10C).

The mean content of glutamine, serine, and arginine $\left(\mathrm{mg} \cdot \mathrm{g}^{-1}\right)$ in the pollen of the biennial fruiting cultivars was in the range of 22.1 ('Radziejowa') - 23.4 ('Laszka'), 22.1 ('Radziejowa')—23.37 ('Laszka'), and 22.1 ('Radziejowa')—22.13 ('Laszka'), respectively. The following range of the content of these amino acids $\left(\mathrm{mg} \cdot \mathrm{g}^{-1}\right)$ was determined in the group of the repeated fruiting cultivars: 19.5 ('Polana') —21.8 ('Pokusa'), 19.5 ('Polana') 21.8 ('Laszka'), and 18.0 ('Polana')—21.4 $\mathrm{mg}^{\prime} \mathrm{g}^{-1}$ ('Polka'), respectively (Figure 10D-F).

The content of glutamine in the pollen of 'Pokusa' and 'Polana' in 2016 was considerably lower than that in 2017 and 2018. Its level in 'Laszka' in 2017 was markedly higher than in 2016 and 2018, whereas in 'Radziejowa', it was clearly lower in 2018 than in 2016 and 2017. The analysis of the differences between the cultivars showed that the pollen of 'Laszka' and 'Radziejowa' in 2016 contained a significantly higher amount of this amino acid than the other cultivars. The content of glutamine in 'Glen Ample' was comparable to that in 'Polka' and significantly higher than in 'Pokusa' and 'Polana'. In 2017, the content of this amino acid in 'Laszka' was significantly higher than the level detected in 'Glen Ample', 'Radziejowa', 'Pokusa', and 'Polka', and the content in 'Polana' was markedly lower than in the other cultivars. In 2018, the glutamine content in 'Glen Ample', 'Pokusa', and 'Polka' was significantly higher than in 'Radziejowa' (Figure 10D).

There were no significant differences in the mean pollen serine content between the cultivars. The analysis of the differences in the content of the amino acids between the study years showed a markedly higher level of serine in 'Laszka' in 2017 than in 2016 and 2018. The content of this amino acid in 'Pokusa' was higher in 2017 and 2018 than in 2016. In turn, in 2016, the serine content was substantially higher in 'Radziejowa' and lower in 'Polana' in comparison with the value recorded in 2018. As for the differences in the serine content between the cultivars, in 2016, the biennial fruiting cultivars exhibited significantly higher values of this parameter than the repeated fruiting group, except for 'Glen Ample' and 'Polka', which had similar serine content. In 2017, the highest level of this amino acid was recorded in the pollen of 'Laszka'. In 2018, considerably higher levels were determined in 'Glen Ample' and 'Pokusa', compared with the other cultivars (Figure 10E).

The mean content of arginine in the pollen of Pokusa' and 'Polana' was significantly lower than in 'Glen Ample' and 'Radziejowa'. The amount of this amino acid in 'Polana' and 'Polka' recorded in 2016 was distinctly lower than in 2018. In turn, 'Pokusa' was characterized by significantly higher arginine content in 2017 than in 2016 and 2018, and 'Laszka' had a clearly lower amount of this compound in 2018 than in 2016-2017. In terms of the differences between the cultivars in the subsequent years, the arginine content in 2016 was clearly lower in 'Polana' than in 'Glen Ample', 'Laszka', 'Radziejowa', and 'Polka' but comparable to that in 'Pokusa', and the level of this amino acid in 'Pokusa' was clearly lower than in 'Laszka' and 'Radziejowa'. In 2017, the level of arginine in 'Polana' was lower than in the other cultivars. The value of this parameter in 2018 was higher in 'Glen Ample', 'Radziejowa', and 'Polka' than in Laszka' and 'Pokusa', whereas the content in 'Polana' was comparable to that in the other cultivars (Figure 10F).

The mean content of glycine, tyrosine, and histidine $\left(\mathrm{mg} \cdot \mathrm{g}^{-1}\right)$ in the pollen of the biennial fruiting cultivars in 2016-2018 was in the range of 17.3 ('Glen Ample')-20.5 ('Laszka'), 12.5 ('Glen Ample')—14.4 ('Laszka'), and 8.5 ('Glen Ample')—9.9 ('Laszka'), respectively. Their content $\left(\mathrm{mg} \cdot \mathrm{g}^{-1}\right)$ in the repeated fruiting cultivars was in the range of 16.1 ('Polana')—18.6 ('Polka'), 11.8 ('Polana')—13.1 ('Pokusa'), and 8.7 ('Polana')—9.0 ('Pokusa'), respectively (Figure 10G-I). 
The pollen grains of 'Laszka' and 'Radziejowa' had a higher mean level of glycine than the other cultivars. As shown by the analysis of the glycine content in the cultivars in each year, in 2017, 'Glen Ample', 'Polana', and 'Pokusa' were characterized by significantly higher levels of this amino acid than in 2016 and 2018. The glycine content in 'Laszka' was markedly lower in 2016 than in 2017 and 2018, and 'Polka' had clearly higher values of this parameter in 2018 than in 2016-2017. In 2016, the pollen grains of 'Radziejowa' had the highest glycine content. Furthermore, the amount of this amino acid in 'Laszka' was quite similar to that in 'Polka' and clearly greater than in 'Glen Ample', 'Pokusa', and 'Polana'. No significant differences between the cultivars in the glycine content were reported in 2017, but in 2018, its level in 'Polka' was markedly lower than in 'Laszka' and higher than in 'Glen Ample', 'Radziejowa', 'Pokusa', and 'Polana' (Figure 10G).

The tyrosine content found in 'Laszka' and 'Polana' in 2016 was comparable to the level detected in 2017 and clearly lower than in 2018. In turn, its amount in 'Pokusa' was significantly lower in 2016 than in 2017-2018, whereas 'Polka' had a markedly higher level of this amino acid in 2017 than in 2016 and 2018. The tyrosine level in the pollen of the biennial fruiting cultivars in 2016 was higher than in the repeated fruiting group. In 2017, the content of this amino acid was significantly lower in 'Polana' than in the other cultivars. In 2018, the level of tyrosine was significantly higher in 'Laszka' and 'Radziejowa' and lower in 'Polka' in comparison with the other cultivars (Figure 10H).

The content of histidine in the individual cultivars in each study year was significantly lower in 'Radziejowa' in 2016 than in 2017-2018. 'Polka' exhibited significantly higher content of this amino acid in 2017 than in 2016 and 2018. In turn, its level in 'Glen Ample', 'Pokusa', and 'Polana' in the first and second years of the study was comparable, but in the third year, the content clearly declined in 'Glen Ample' and 'Pokusa' and increased in 'Polana'. In terms of the differences between the examined cultivars in 2016, the hidstidine content in 'Radziejowa' was comparable to that in 'Laszka' and significantly exceeded the amounts found in 'Glen Ample', 'Pokusa', 'Polka', and 'Polana'. In 2017, there were no significant differences in the content of this amino acid between the cultivars. In 2018, Radziejowa' and 'Polana' were characterized by markedly higher histidine content than 'Glen Ample', 'Pokusa', and 'Polka (Figure 10I).

\subsection{Total Fat Content}

The average total fat content in the pollen grains of the biennial and repeated fruiting $R$. idaeus cultivars analyzed in 2016-2018 was in the range of 3.5 ('Glen Ample') - 4.4\% ('Radziejowa') and 2.8 ('Polka') - $3.6 \%$ ('Polana'), respectively. In the former group of cultivars, the value of this parameter in 'Laszka' was lower than in 'Radziejowa' but higher than the fat content in 'Glen Ample'. At the same time, the total pollen fat content in 'Glen' Ample' was comparable to that determined in 'Pokusa' and 'Polana', and 'Polka' exhibited a significantly lower value than 'Polana' (Figure 11).

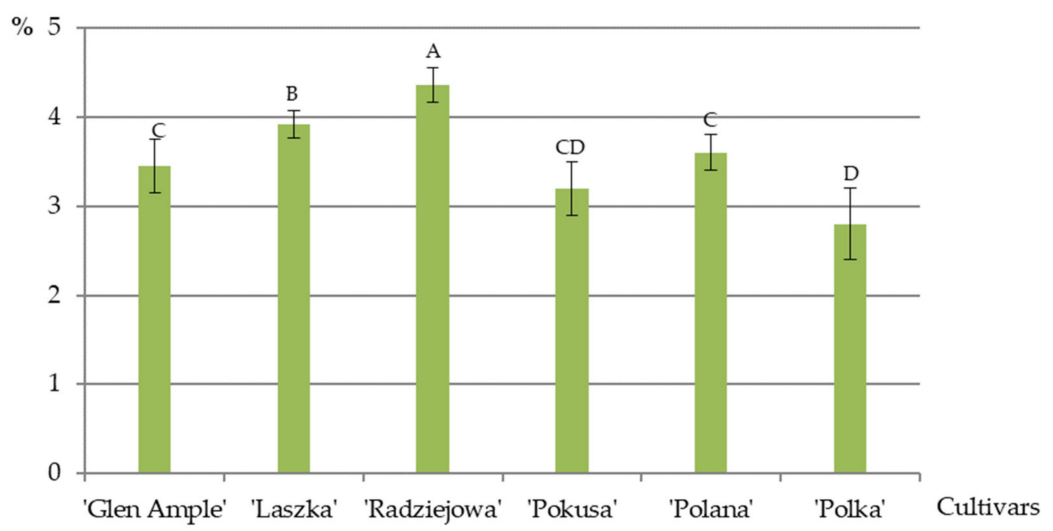

Figure 11. Average total fat content in pollen grains of $R$. idaeus cultivars. Explanations: means followed by the same letter do not differ between the cultivars at a significance level $\alpha=0.05$; (number of repetitions $\mathrm{n}=3$ ). Bars indicate standard deviation. 


\subsection{Fatty Acid Content in Pollen}

Saturated fatty acids (SFAs). The content of total saturated fatty acids in the fat extracted from the pollen of the biennial and repeated fruiting $R$. idaeus cultivars was in the range of 40.7 ('Glen Ample')—46.4\% ('Laszka') and 32.7 ('Polka')—44.8\% ('Polana'), respectively (Figure 12). 'Glen Ample', 'Radziejowa', and 'Pokusa' had significantly higher content of SFAs than 'Polka' and a lower level than 'Laszka' and 'Polana'. The pollen of all six cultivars contained myristic, stearic, and palmitic acids. Their concentration was in the range of 0.4 ('Polka')-1.7\% ('Laszka), 5.1 ('Polka')—8.95\% ('Laszka' and 'Polana'), and 26.3 ('Polka')—33.0\% ('Polana'), respectively (Figure 12, Table 4).

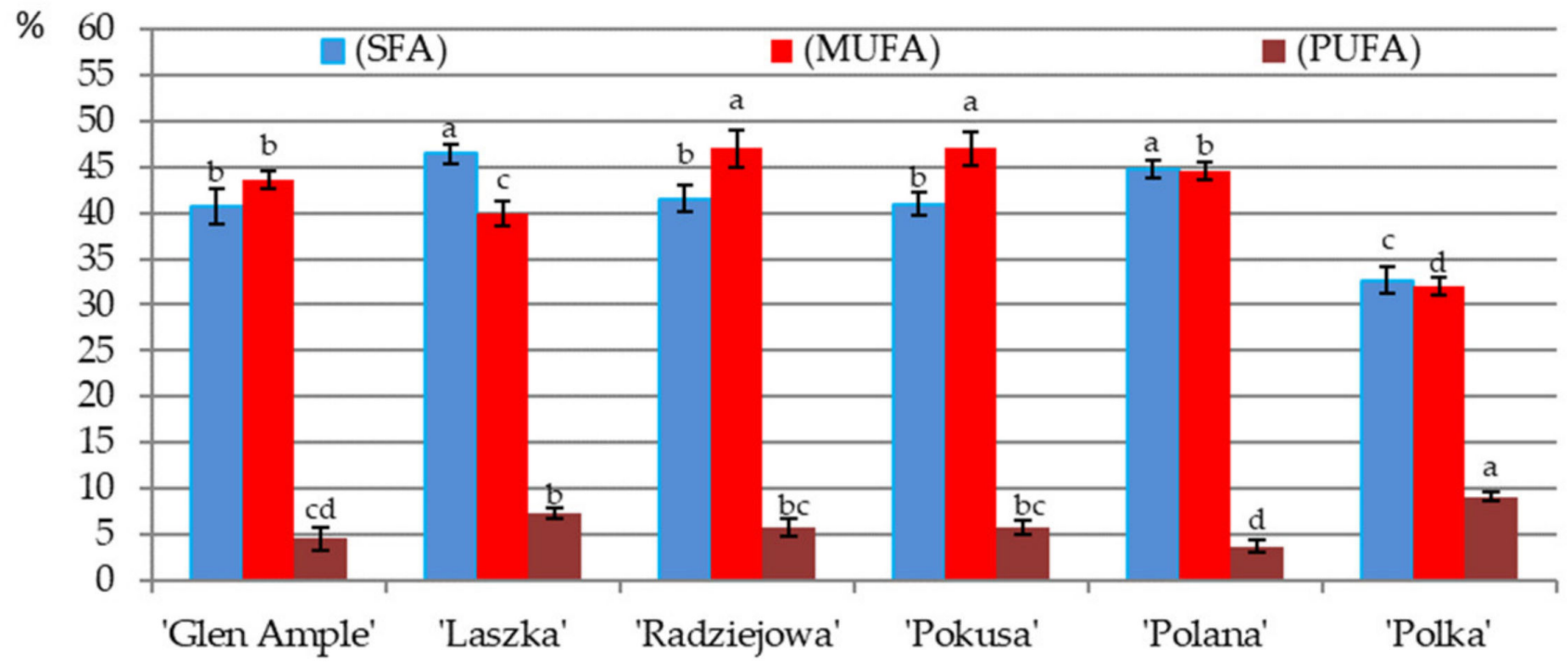

Figure 12. Percentage content of saturated fatty acids (SFAs), monounsaturated fatty acids (MUFAs), and polyunsaturated fatty acids (PUFAs) in the fat extracted from pollen grains of $R$. idaeus cultivars. Explanations: means followed by the same letter are not significantly different within the cultivar for SFAs, MUFAs, and PUFAs at a significance level $\alpha=0.05$; (number of repetitions $n=3$ ). Bars indicate standard deviation.

The pollen of 'Polka' was characterized by significantly lower content of palmitic acid in comparison with the other cultivars. The content of this acid in 'Laszka' was comparable to its level in 'Glen Ample' and substantially higher than in 'Pokusa', 'Radziejowa', and 'Polana'. The content of palmitic acid in the 'Polana' cultivar was comparable to that in 'Radziejowa' and considerably higher than in the other cultivars. Its concentration in 'Radziejowa' was similar to the level in 'Pokusa'.

The level of stearic acid in the pollen of 'Polana' was distinctly lower than in the other cultivars. The pollen of the analyzed cultivars (except for 'Polka') contained lauric and behenic acids in a concentration range of 0.2 ('Pokusa') $-0.6 \%$ ('Laszka') and 0.4 ('Radziejowa')-2.1\% ('Laszka'), respectively. The content of lauric acid in the pollen of 'Polana' was significantly lower than in 'Laszka' and higher than in 'Glen Ample', 'Radziejowa', and 'Pokusa'.

Four of the six analyzed cultivars contained lignoceric acid in their pollen: 'Laszka', 'Radziejowa', 'Glen Ample', and 'Pokusa'. The pollen of the biennial fruiting cultivars contained caprylic acid; its level in 'Laszka' was significantly higher than in 'Polka', 'Radziejowa', and 'Glen Ample'. Additionally, capric, pentadecanoic, and arachidic acids were detected in the pollen of 'Glen Ample' and 'Laszka', whereas caproic acid was contained in the pollen of 'Glen Ample' and 'Polka' (Figure 12, Table 4).

Monounsaturated fatty acids (MUFAs). The total monounsaturated fatty acids accounted for 43.6, 40, and 47\% in the pollen of 'Glen Ample', 'Laszka', and 'Radziejowa', respectively, and 47, 44.5, and 32\% in 'Pokusa', 'Polana', and 'Polka', respectively. A clearly lower MUFA level was determined in the pollen of 'Polka', whereas 'Radziejowa' and 
'Pokusa' exhibited a higher amount of these acids than the other cultivars. At the same time, the value of this parameter in 'Laszka' was significantly lower than in 'Glen Ample' and 'Polana' (Figure 12). MUFAs contained in the pollen of the analyzed cultivars were represented by palmitoleic, oleic, and elaidic acids. Palmitoleic acid constituted from $2.2 \%$ ('Laszka') to 3.7\% ('Polka'). Its content in 'Laszka' was considerably lower than in the other cultivars. The sum of oleic and elaidic acids was in the range of 28.3 ('Polka') $-44.4 \%$ ('Radziejowa'). In 'Laszka', this value was significantly higher than in 'Polka' and lower than in 'Glen Ample', 'Radziejowa', 'Pokusa', and 'Polana' (Figure 12, Table 4).

Polyunsaturated fatty acids (PUFAs). The proportion of polyunsaturated fatty acids in the fat extracted from the pollen of the biennial and repeated fruiting cultivars was in the range of 4.6 ('Glen Ample') - 5.8\% ('Radziejowa') and 3.7 ('Polana')—9.1\% ('Polka'), respectively. 'Polka' had a clearly higher PUFA level than the other cultivars. The value of this parameter in 'Laszka' was significantly higher than in 'Glen Ample' and 'Polana', and the latter cultivar had clearly lower PUFA content than in 'Radziejowa' and 'Pokusa' (Figure 12). The pollen grains of the analyzed cultivars also contained cis-13,16-docosadienoic, linoleic, and linoelaidic acids. The content of cis-13,16-docosadienoic acid was in the range of 0.24 ('Pokusa') - 0.71\% ('Polka'). The level of this acid in 'Glen Ample', Radziejowa', and 'Polana' was higher than in 'Pokusa' and lower than in 'Laszka' and 'Polka'. The sum of linoleic and linoelaidic acids ranged from 3.24\% ('Polana') to 5.52\% ('Pokusa'). The value of this parameter in the 'Laszka' cultivar was lower than in 'Radziejowa' and 'Pokusa' and higher than in 'Glen Ample', 'Polana', and 'Polka'. Moreover, 'Glen Ample' and 'Laszka' contained $\alpha$-linolenic acid; the content of this acid was substantially lower in the former cultivar than in the latter (Figure 12, Table 4).

Table 4. Profile of saturated fatty acids (SFAs), monounsaturated fatty acids (MUFAs), and polyunsaturated fatty acids (PUFAs) in the pollen of R. idaeus cultivars (\%).

\begin{tabular}{|c|c|c|c|c|c|c|}
\hline \multirow{2}{*}{ Fatty Acids } & \multicolumn{3}{|c|}{ Biennial Fruiting Cultivars } & \multicolumn{3}{|c|}{ Repeated Fruiting Cultivars } \\
\hline & ‘Glen Ample' & 'Laszka' & 'Radziejowa' & 'Pokusa' & 'Polana' & 'Polka' \\
\hline \multicolumn{7}{|c|}{ Saturated fatty acids (SFA) } \\
\hline hexanoic acid (caproic acid) C6:0 & $0.18 \pm 0.01^{b}$ & nd & nd & nd & nd & $0.89 \pm 0.07^{a}$ \\
\hline octanoic acid (caprylic acid) C8:0 & $0.15 \pm 0.01^{b}$ & $0.64 \pm 0.04^{\mathrm{a}}$ & $0.07 \pm 0.00^{c}$ & nd & nd & $0.03 \pm 0.00^{\mathrm{d}}$ \\
\hline decanoic acid (capric acid) C10:0 & $0.10 \pm 0.02^{\mathrm{a}}$ & $0.06 \pm 0.01^{\mathrm{a}}$ & nd & nd & nd & nd \\
\hline n-dodecanoic acid (lauric acid) C12:0 & $0.17 \pm 0.02^{c}$ & $0.60 \pm 0.08^{a}$ & $0.14 \pm 0.02^{\mathrm{c}}$ & $0.16 \pm 0.02^{c}$ & $0.30 \pm 0.04^{b}$ & nd \\
\hline tetradecanoic acid (myristic acid) C14:0 & $0.88 \pm 0.17^{\mathrm{c}}$ & $1.73 \pm 0.14^{\mathrm{a}}$ & $0.73 \pm 0.10^{c}$ & $0.76 \pm 0.08^{c}$ & $1.02 \pm 0.20^{b}$ & $0.37 \pm 0.05^{\mathrm{d}}$ \\
\hline pentadecanoic acid (pentadecylic acid) C15:0 & $0.22 \pm 0.05^{\mathrm{b}}$ & $0.33 \pm 0.07^{\mathrm{a}}$ & nd & nd & nd & nd \\
\hline hexadecanoic acid (palmitic acid) C16:0 & $28.06 \pm 0.84^{\mathrm{d}}$ & $30.42 \pm 1.29 \mathrm{~cd}$ & $31.50 \pm 0.97^{\mathrm{ab}}$ & $31.16 \pm 1.08^{b c}$ & $32.98 \pm 1.14^{\mathrm{a}}$ & $26.25 \pm 0.63^{\mathrm{e}}$ \\
\hline octadecanoic acid (stearic acid) C18:0 & $8.33 \pm 0.36^{\mathrm{a}}$ & $8.94 \pm 0.25^{\mathrm{a}}$ & $8.37 \pm 0.54^{\mathrm{a}}$ & $8.22 \pm 0.23^{\mathrm{a}}$ & $8.95 \pm 0.47^{\mathrm{a}}$ & $5.12 \pm 0.28^{\mathrm{d}}$ \\
\hline eicosanoic $a$ cid (arachidic acid) C20:0 & $0.43 \pm 0.04^{\mathrm{b}}$ & $1.00 \pm 0.13^{\mathrm{a}}$ & nd & nd & 0.57 & nd \\
\hline docosanoic acid (behenic acid) C22:0 & $1.73 \pm 0.24^{b}$ & $2.05 \pm 0.41^{\mathrm{a}}$ & $0.38 \pm 0.08^{d}$ & $0.46 \pm 0.06^{\mathrm{d}}$ & $0.93 \pm 0.04^{c}$ & nd \\
\hline tetracosanoic acid (lignoceric acid) C24:0 & $0.44 \pm 0.05^{\mathrm{b}}$ & $0.61 \pm 0.09^{\mathrm{a}}$ & $0.36 \pm 0.04^{\mathrm{b}}$ & $0.19 \pm 0.03^{c}$ & nd & nd \\
\hline \multicolumn{7}{|c|}{ Monounsaturated fatty acid (MUFA) } \\
\hline $\begin{array}{c}\text { cis -9-hexadecenoic acid (palmitoleic acid) } \\
\text { C16:1n7 }\end{array}$ & $2.34 \pm 0.23^{b}$ & $2.19 \pm 0.15^{b}$ & $2.62 \pm 0.55^{b}$ & $2.86 \pm 0.67^{b}$ & $2.41 \pm 0.30^{\mathrm{b}}$ & $3.72 \pm 0.45^{\mathrm{a}}$ \\
\hline $\begin{array}{c}\text { is }-9 \text { - octadecenoic acid (oleic acid) C18:1n9c }+ \\
\text { trans -9-octadecenoic acid (elaidic acid) } \\
\text { C18:1n9t }\end{array}$ & $41.24 \pm 1.52^{\mathrm{a}}$ & $37.77 \pm 1.74^{\mathrm{b}}$ & $44.39 \pm 2.07^{\mathrm{a}}$ & $44.10 \pm 2.94^{\mathrm{a}}$ & $42.12 \pm 2.38^{a}$ & $28.30 \pm 1.90^{c}$ \\
\hline \multicolumn{7}{|c|}{ Polyunsaturated fatty acid (PUFA) } \\
\hline $\begin{array}{c}\text { cis -9,12-octadecadienoic acid (linoleic acid) } \\
\text { C18:2n6c }+ \text { trans- 9,12-octadecadienoic acid } \\
\text { (linoelaidic acid) C18:2n6t }\end{array}$ & $3.81 \pm 0.33^{c}$ & $4.56 \pm 0.27^{b}$ & $5.32 \pm 0.29^{a}$ & $5.52 \pm 0.30^{a}$ & $3.24 \pm 0.26^{c}$ & $3.40 \pm 0.26^{c}$ \\
\hline $\begin{array}{l}\text { cis-9,12,15-octadecatrienoic acid ( } \alpha \text {-linolenic } \\
\text { acid) C18:3n3(alpha) }\end{array}$ & $0.36 \pm 0.07^{b}$ & $2.13 \pm 0.35^{\mathrm{a}}$ & nd & nd & nd & nd \\
\hline $\begin{array}{l}\text { cis -13,16-docosadienoic acid (docosadienoate) } \\
\text { C22:2n6 }\end{array}$ & $0.44 \pm 0.03^{\mathrm{b}}$ & $0.61 \pm 0.05^{\mathrm{a}}$ & $0.44 \pm 0.02^{b}$ & $0.24 \pm 0.03^{c}$ & $0.48 \pm 0.04^{b}$ & $0.71 \pm 0.06^{\mathrm{a}}$ \\
\hline
\end{tabular}

Explanations: data are expressed as mean percentage \pm SD, values in the same row that do not share the same superscript letter are significantly different according to the analysis of variance and Tukey's post hoc test at a significance level $\alpha=0.05 ;$ (number of repetitions $\mathrm{n}=3$ ); nd-not detected (below the level of detection LOD; $<$ LOD $=0.016$ ).

\subsection{Omega-3, Omega-6, and Omega-9 Acids}

Palmitoleic acid and oleic + elaidic acid represented the omega-9 group of MUFAs identified in the pollen of the R. idaeus cultivars. Their content was in the range of $2.2 \%$ 
('Laszka')—3.7\% ('Polka') and 28.3 ('Polka')—44.4\% ('Radziejowa'), respectively. The level of omega-9 fatty acids was clearly higher in the pollen of 'Radziejowa' and 'Pokusa' and lower in 'Polka', in comparison with the other cultivars. In turn, their level in 'Laszka' was markedly lower than in 'Glen Ample' and 'Polana'.

In the group of PUFAs, omega- 6 acids in the analyzed pollen were represented by linoelaidic acid and 13,16-docosadienoic acid. Their content was in the range of 3.7 ('Polana') 9.11\% ('Polka') and 0.24 ('Pokusa') — $0.71 \%$ ('Polka'), respectively. 'Polka' had a substantially higher concentration of omega- 6 acids than the other cultivars. The value of this parameter in 'Polana' pollen grains was significantly lower than in the case of 'Laszka', 'Radziejowa', and 'Pokusa' and comparable to the content detected in 'Glen Ample'. Omega-3 acids were represented by $\alpha$-linolenic acid, which was detected in 'Glen Ample' and 'Laszka' ( $0.4 \%$ and $2.1 \%$, respectively). The acid was not detected in the other cultivars (Figure 13, Table 4).

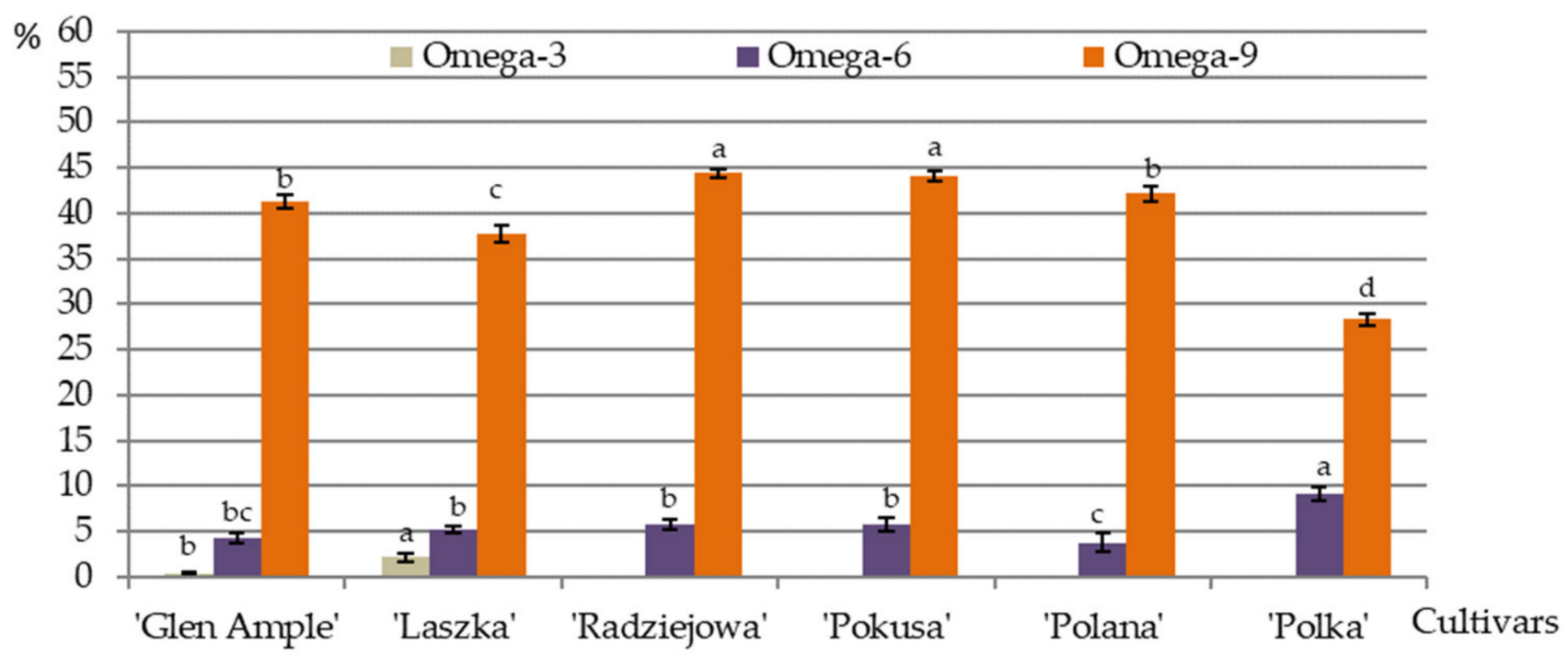

Figure 13. Percentage content of essential fatty acids in the pollen grains of six $R$. idaeus cultivars. Explanations: means followed by the same letter are not significantly different within the cultivar for the omega-3, omega-6, and omega- 9 fatty acids at a significance level $\alpha=0.05$; (number of repetitions $n=3$ ). Bars indicate standard deviation. Omega-3, total amount of $\alpha$-linolenic acid (C18:3n3 alpha); Omega-6, total amount of linoleic acid (C18:2n6c), linoelaidic acid (C18:2n6t), cis-13,16-docosadienoic acid (C22:2n6); Omega-9, total amount of palmitoleic acid (C16:1n7), oleic acid (C18:1n9c), elaidic acid $(\mathrm{C} 18: \ln 9 \mathrm{t})$.

\subsection{Content of Selected Minerals in Pollen Exine}

The EDS microanalysis of elements present in the pollen exine in the $R$. idaeus cultivars demonstrated that the average content of carbon and oxygen 2 in 2016-2018 measured at the electron penetration depth of $2 \mu \mathrm{m}$ was in the range of (wt.\%) 67.2 ('Radziejowa')70.4 ('Polka') and 26.6 ('Glen Ample')—28.1 ('Radziejowa'), respectively (Figure 14A,B). The mean content of $\mathrm{K}, \mathrm{P}, \mathrm{Ca}, \mathrm{Mg}, \mathrm{S}, \mathrm{Mn}$, and $\mathrm{Cl}$ in the pollen of the examined cultivars in 2016-2018 was in the following range: (wt.\%) K-1.15 ('Polka') -1.79 ('Pokusa'), $\mathrm{P}-0.52$ ('Laszka') -1.5 ('Glen Ample'), Ca-0.38 ('Polka')—0.60 ('Laszka'), Mg-0.31 ('Radziejowa')—0.84 ('Pokusa'), S—0.45 ('Polka')—0.69 ('Laszka'), Mn—0.050 ('Polana') — 0.083 ('Laszka'), and $\mathrm{Cl}-0.058$ ('Polana')—0.093 ('Radziejowa') (Figure 14C-I).

The analysis of the differences in the mean content of potassium in the pollen exine between the cultivars showed that 'Pokusa' exhibited the highest content of this element, whereas significantly lower values were found in 'Radziejowa' and 'Laszka', but the lowest levels were determined in 'Polana' and 'Polka' (Figure 14C). The lowest amount of phosphorus in the pollen exine was recorded for 'Polka', while considerably higher content was found in 'Polana' followed by 'Pokusa'. The highest level of this element was shown in 'Glen Ample', 'Radziejowa', and 'Laszka', whereas there were no significant differences 
between these three cultivars (Figure 14D). The mean content of calcium in 'Glen Ample' was much higher than in 'Polka', and a distinctly higher value of this element was recorded in 'Laszka', 'Radziejowa', 'Pokusa', and 'Polana' (Figure 14E). The magnesium level in the outer layer of the pollen grain of 'Glen Ample' and 'Polka' was significantly higher than in 'Radziejowa'. Considerably higher content of this element was shown for 'Laszka' and 'Polana', while the highest level was detected in 'Pokusa' (Figure 14F). The lowest amount of sulfur was found in 'Polka', while 'Laszka' had the highest $\mathrm{S}$ content, with quite comparable levels of this element in the other four cultivars (Figure 14G). The chlorine content in 'Radziejowa' significantly exceeded the value recorded for 'Glen Ample' and 'Pokusa'. Even higher amounts of this element were shown for 'Laszka', while the highest levels were recorded in 'Polana' and 'Polka' (Figure 14H). The average manganese content in the exine of 'Glen Ample', 'Pokusa', 'Polana', and 'Polka' was quite similar and was below the value recorded for 'Radziejowa'. The latter cultivar had a distinctly lower level of Mn than 'Laszka' (Figure 14I).
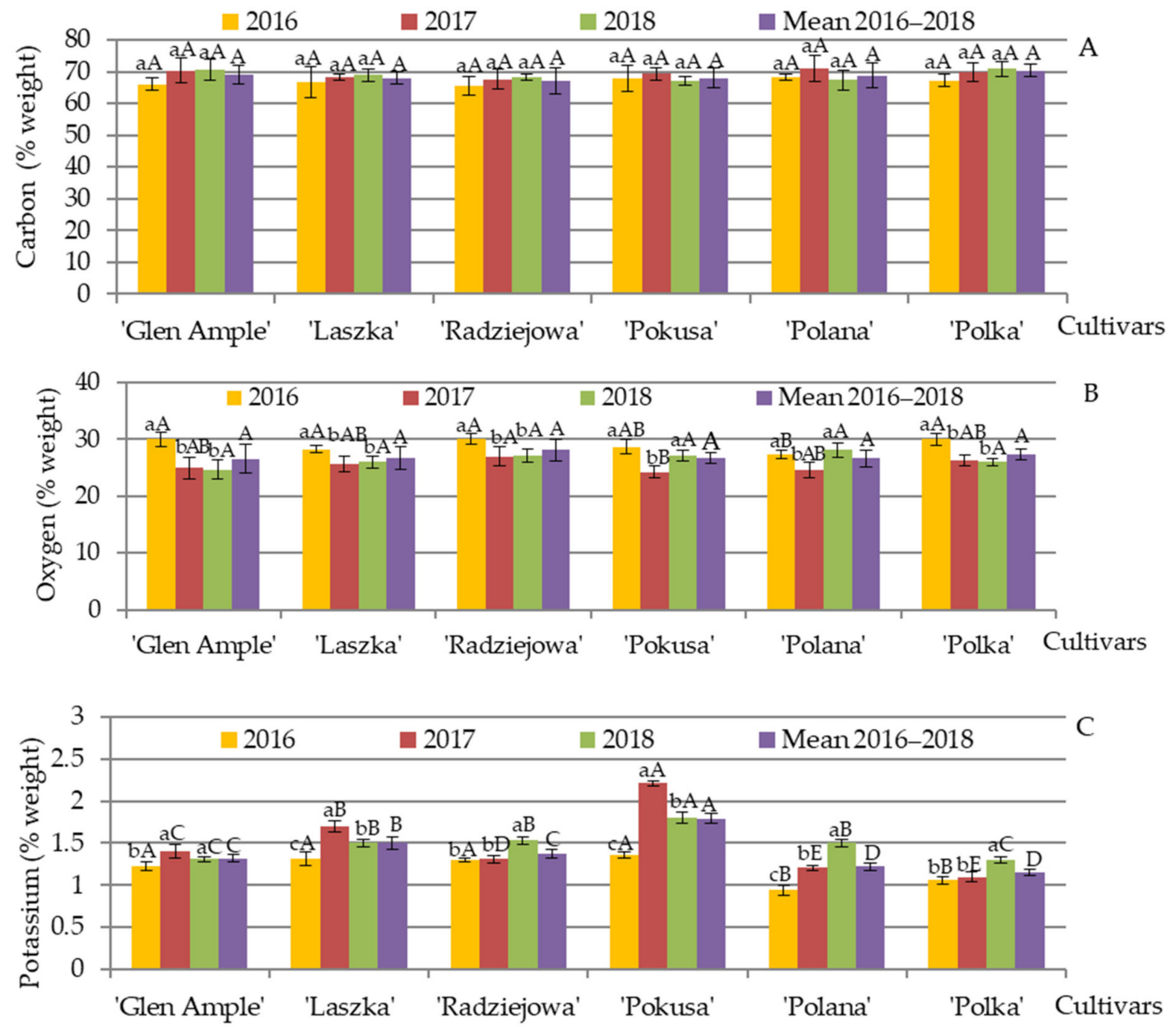

Figure 14. Cont. 

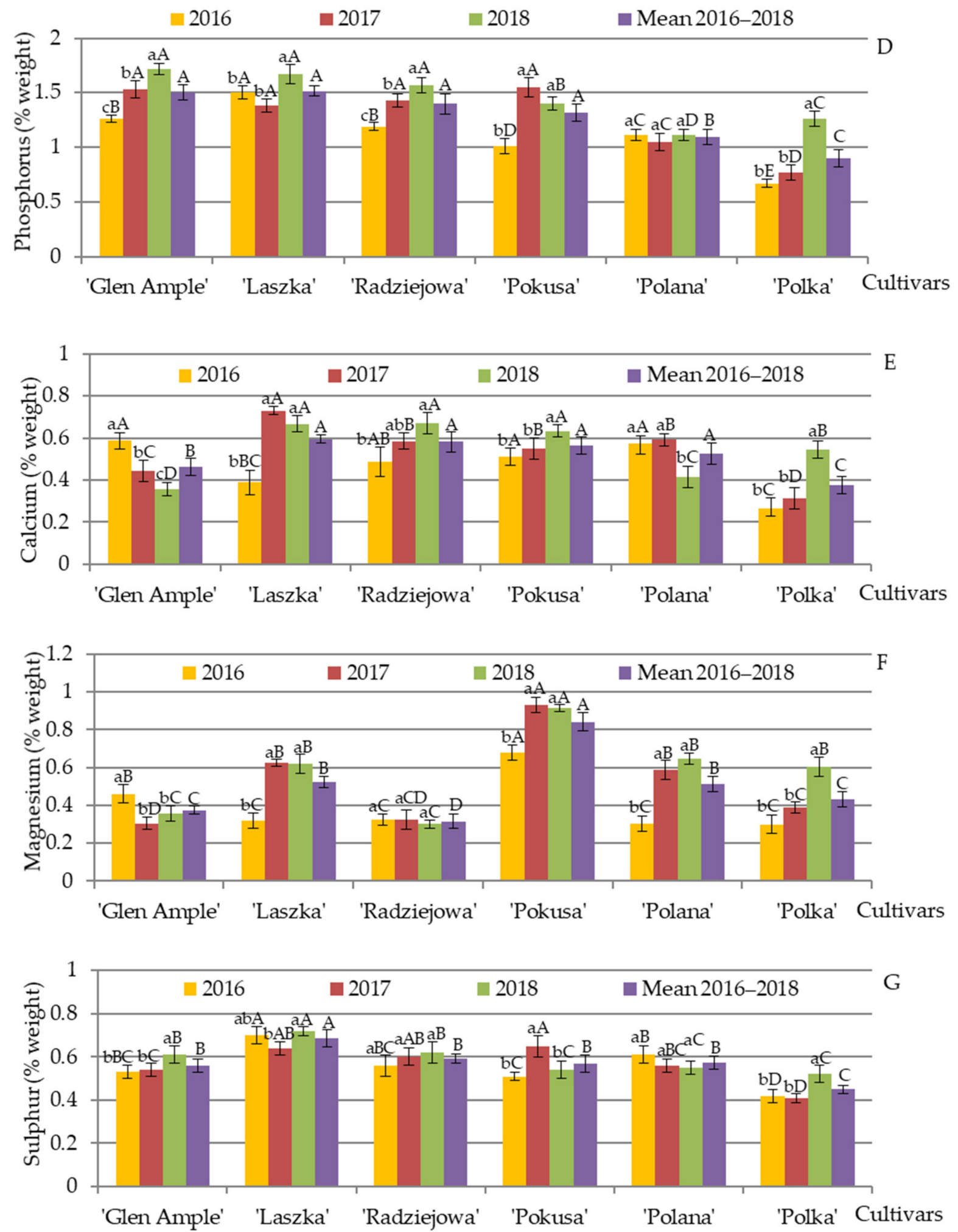

Figure 14. Cont. 

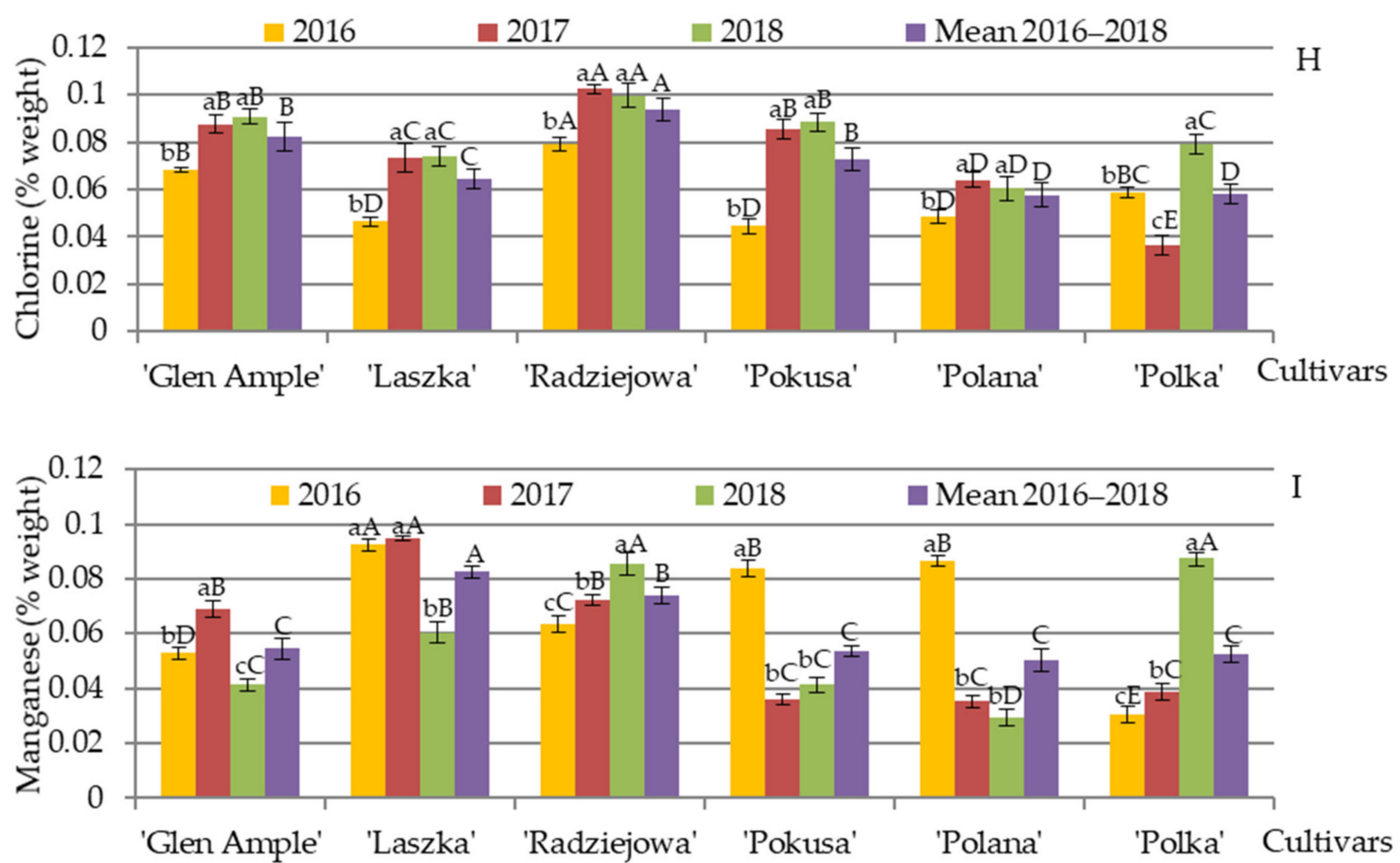

Figure 14. (A-I). Content of selected elements in the pollen exine in six Rubus idaeus cultivars. Explanations: for each element, means followed by the same small letter are not significantly different within the cultivar for the years and means followed by the same capital letter do not differ between the cultivars in each year of the study at a significance level $\alpha=$ 0.05 ; (number of repetitions in each year $n=25$ ). Bars indicate standard deviation. The content of elements was determined with the use of energy dispersive X-ray spectroscopy (EDS).

\section{Discussion}

\subsection{Micromorphology of Stamen Epidermis}

The six Rubus idaeus cultivars studied have striated ornamentation of the anther epidermis cuticle with characteristic multidirectional arrangement of undulating striae. In turn, literature reports on other species from the genus Rubus indicate that the surface of the anther epidermis is smooth in Rubus ambulans, R. ellipticus, R. fasciculatiformis, R. perlongus, and R. stohrii and slightly hairy in $R$. ramachandrae $[68,69]$. The varied characteristic pattern of the cuticle ornamentation of the epidermis of floral elements in closely related taxa is of key importance for cuticle function. The multifunctional cuticle layer regulates fluxes of gases and water with dissolved substances into stamen cells and constitutes an integral protective layer against damage and mechanical stress $[19,70,71])$. Additionally, it protects the genetic material against biotic and abiotic environmental factors [24], and indirectly protects developing pollen grains [72]. Our study revealed that mature pollen grains in the six raspberry cultivars were released in the initial stage of pollen release through a slit enlarging towards the opposite pole at the anther apex. This is consistent with the results reported by Endress and Stumpf [73], who found that most species in the order Rosales release pollen grains through longitudinal anther slits in dorsal stamens with a narrow connective and a zone of transition of the anther into the filament located in a deep base or furrow.

\subsection{Number and Size of Stamens}

In the present study, the number of stamens in the flowers of the biennial and repeated fruiting $R$. idaeus cultivars was within the range of 102 ('Glen Ample')-113 ('Laszka') and 93 ('Polka') -112 ('Polana'), respectively. The number was higher (except 'Polka' and 'Glen Ample') than the values of this parameter reported by other authors for the following cultivars of red raspberry: 'Polka' (83-88) and 'Meeker' (88-93) [74,75]. The 
average number of stamens in a single flower of the six raspberry cultivars examined also exceeded the value of $14-90$ described in other Rubus species, i.e., $R$. benguetensis, R. cumingii, R. declinis, R. heterosephalus, $R$. macilentus, $R$. mearrsii, R. moorei, R. nebulosus, $R$. nessensis, $R$. novoguineensis, $R$. royenii, $R$. scissus, $R$. sengorensis, and $R$. sundaicus [76-80]. At the same time, the average number of stamens obtained in the present study coincided with the range of 24-185 reported for R. elongatus, $R$. glomeratus, $R$. keleterios, $R$. lineatus, and $R$. moluccanus flowers [76]. However, it was lower than the number of stamens (115-230) described in $R$. alceifolius, $R$. becardii, $R$. divaricatus, $R$. grabowskii, $R$. insularis, R. laciniatus, R. lidebergii, R. pedemontanus, R. polyanthemus, R. pyramidalis, R. radula, R. rolfei, R. sprengelii, $R$. vestitus, $R$. vigorosus, and $R$. wahlbergii $[76,78]$ (Table 5).

Table 5. Number of stamens in flowers of selected Rubus species.

\begin{tabular}{|c|c|c|c|c|c|c|c|}
\hline No. & Species/Cultivar & $\begin{array}{c}\text { Number of } \\
\text { Stamens/Flower }\end{array}$ & Author & No. & Species/Cultivar & $\begin{array}{c}\text { Number of } \\
\text { Stamens/Flower }\end{array}$ & Author \\
\hline 1. & R. alceifolius & $160-230$ & \multirow{5}{*}{ [76] } & 28. & R. malvaceus & $100-200$ & \multirow{2}{*}{ [76] } \\
\hline 2. & R. becardii & 115 & & 29. & R. mearrsii & $60-90$ & \\
\hline 3. & R. benguetensis & $50-80$ & & 30. & R. megacarpus & $30-185$ & [77] \\
\hline 4. & R. chrysophyllus & $50-100$ & & 31. & R. moluccaanus & 30-185 & [76] \\
\hline 5. & R. cumingii & 60 & & 32. & R. moorei & $40-50$ & \multirow{2}{*}{ [79] } \\
\hline 6. & R. diclinis & $18-40$ & [77] & 33. & R. nebulosus & $45-60$ & \\
\hline 7. & R. divaricatus & 120 & [78] & 34. & R. nessensis & 77 & [78] \\
\hline 8. & R. elongatus & $80-125$ & \multirow{2}{*}{ [76] } & 35. & R. novoguineensis & $14-20$ & [77] \\
\hline 9. & R. glomeratus & $24-120$ & & 36. & R. pedemontanus & 193 & \multirow{4}{*}{ [78] } \\
\hline 10. & R. grabowskii & 171 & \multirow{2}{*}{ [78] } & 37. & R.plicatus & 106 & \\
\hline 11. & R. hartmanii & 105 & & 38. & R. polyanthemus & 200 & \\
\hline 12. & R. heterosephalus & $70-90$ & [76] & 39. & R. pyramidalis & 172 & \\
\hline 13 & R. idaeus 'Glen Ample' & 102 & \multirow{2}{*}{ [PS] } & 40. & R.pyrifolius & $40-100$ & [76] \\
\hline 14. & R. idaeus 'Laszka' & 113 & & 41. & R. radula & 134 & [78] \\
\hline \multirow{2}{*}{15.} & \multirow{2}{*}{ R. idaeus 'Meeker' } & \multirow{2}{*}{$88-93$} & \multirow{2}{*}[74]{} & 42. & R. rolfei & $120-140$ & [76] \\
\hline & & & & 43. & R. royenii & $40-60$ & \multirow{6}{*}{ [77] } \\
\hline 16. & R. idaeus 'Pokusa' & 98 & \multirow{3}{*}{ [PS] } & 44. & R. royenii 'Hispidus' & $14-20$ & \\
\hline 17. & R. idaeus 'Polana' & 112 & & 45. & R. royenii 'Ikilimbu' & $45-60$ & \\
\hline \multirow[t]{2}{*}{18.} & \multirow[t]{2}{*}{ R. idaeus 'Polka' } & 93 & & \multirow[t]{2}{*}{46.} & \multirow[t]{2}{*}{ R. royenii 'Royenii' } & \multirow[t]{2}{*}{$20-40$} & \\
\hline & & $83-88$ & [75] & & & & \\
\hline 19. & R. idaeus 'Radziejowa' & 108 & [PS] & 47. & R. scissus & 47 & \\
\hline 20. & R. infestus & 102 & \multirow{2}{*}{ [78] } & 48. & R. sengorensis & 20 & [81] \\
\hline 21. & R. insularis & 205 & & 49. & R. sosogenensis & 100 & [76] \\
\hline 22. & R. keleterios & $85-125$ & [76] & 50. & R. sprengelii & 125 & [78] \\
\hline 23 & R. laciniatus & 152 & \multirow{2}{*}{ [78] } & 51. & R. sundaicus & 65 & {$[76]$} \\
\hline 24. & R. lidebergii & 172 & & 52. & R. vestitus & 217 & \multirow{3}{*}{ [78] } \\
\hline 25. & R. lineatus & $50-150$ & \multirow{2}{*}{ [76] } & 53. & R. vigorosus & 132 & \\
\hline 26. & R. luzonenesis & $50-100$ & & 54. & R. wahlbergii & 170 & \\
\hline 27. & R. macilentus & $60-90$ & [80] & 55. & $\begin{array}{l}\text { Rubus subgenus Rubus } \\
\text { Watson 'Gazda' }\end{array}$ & $103-125$ & [75] \\
\hline
\end{tabular}

The length of the stamens in the flowers of the biennial and repeated fruiting cultivars examined in the present study ranged from 3.5 ('Laszka') to $4.8 \mathrm{~mm}$ ('Glen Ample') and was similar to the values (3-6.9 mm) reported in R. clementis, R. ideaus 'Polka', R. moorei, and $R$. nebulosus $[75,77,79]$. At the same time, these values were higher than the range of 
1.0-3.01 mm measured in the flowers of R. chrysophyllus, R. ellipticus, R. fraxinifolius, R. lineatus, $R$. macilentus, $R$. moluccanus, $R$. rosifolius, $R$. royenii 'Hispidus', and $R$. sengorensis $[77,80-82]$. However, they were lower than the range of 4.8-12 mm reported for Rubus sp., $R$. benguetensis, $R$. cordiformis, R. diclinis, R. laconensis, R. lineatus, R. luzoniensis, R. megacarpus, R. pyrifolius, R. saxatilis 'Gazda', R. sorsogonensis, and R. sundaicus [76,77,82,83] (Table 6).

Table 6. Length of filaments and anthers and height of stamens in flowers of selected Rubus species.

\begin{tabular}{|c|c|c|c|c|c|}
\hline \multirow{2}{*}{ No. } & \multirow{2}{*}{ Genus/Species/Cultivar } & \multicolumn{2}{|c|}{ Length } & \multirow{2}{*}{$\begin{array}{l}\text { Height } \\
\text { Stamen }\end{array}$} & \multirow{2}{*}{ Author } \\
\hline & & Filament & Anther & & \\
\hline 1. & R. alcelifolius & nd & nd & 4.0 & [82] \\
\hline 2. & R. benguetensis & 5 & $0.5-0.8$ & $5.5-5.8$ & [76] \\
\hline 3. & R. chamaemorus & nd & nd & 4.0 & [84] \\
\hline 4. & R. chrysophyllus & nd & nd & 2.2 & [82] \\
\hline 5. & R. clementis & 2.5 & $1-1.5$ & $3.5-4.0$ & \\
\hline 6. & R. cordiformis & 7 & $1-1.5$ & $8-8.5$ & [77] \\
\hline 7. & R. diclinis & 4.5 & $0.6-1.0$ & $5.1-5.5$ & \\
\hline 8. & R. ellipticus & nd & nd & 2.7 & [82] \\
\hline 9. & R. elongatus & $2-2.5$ & $0.8-2.3$ & $2.8-4.8$ & [76] \\
\hline 10. & R. fraxinifolius & nd & nd & 1.9 & [82] \\
\hline 11. & R. idaeus 'Polka' & nd & nd & $3.6-6.9$ & [75] \\
\hline 12. & R. laconensis & nd & nd & $6-10$ & [83] \\
\hline \multirow{2}{*}{13.} & \multirow{2}{*}{ R. lineatus } & 4 & $0.8-1$ & $4.8-5.0$ & [76] \\
\hline & & nd & nd & 1.4 & [83] \\
\hline 14. & R. luzoniensis & 4.5 & 0.5 & 5.0 & [76] \\
\hline 15. & R. macilentus & nd & nd & 3.2 & [80] \\
\hline 16. & R. megacarpus & 10 & 2 & 12 & [77] \\
\hline 17. & R. moluccanus & nd & nd & 3.0 & [82] \\
\hline 18. & R. moorei & $2.5-3.5$ & $0.5-1.5$ & $3.0-5.0$ & \multirow{2}{*}{ [79] } \\
\hline 19. & R. nebulosus & $2.5-3.5$ & $0.5-1.5$ & $3.0-5.0$ & \\
\hline 20. & R. novoguineensis & 2.5 & 1 & 3.5 & [77] \\
\hline \multirow{2}{*}{21.} & \multirow{2}{*}{ R.pyrifolius } & 6.5 & $0.5-0.8$ & $7.0-7.3$ & [76] \\
\hline & & nd & nd & 4.8 & \multirow{2}{*}{ [82] } \\
\hline 22. & R. rosifolius & nd & nd & 2.5 & \\
\hline 23. & R. royenii 'Hispidus' & 1.5 & 1 & 2.5 & \multirow{3}{*}{ [77] } \\
\hline 24. & R. royenii ‘Ikilimbu & 2.5 & $1.2-1.5$ & $3.7-4.0$ & \\
\hline 25. & R. royenii 'Royenii' & 2.5 & 1 & 3.5 & \\
\hline 26. & R. saxatilis 'Gazda' & nd & nd & $5.9-6.9$ & [75] \\
\hline 27. & R. sengorensis & nd & nd & $1-2$ & [81] \\
\hline 28. & R. smithii & 3 & $1.5-2.0$ & $4.5-5.0$ & \multirow{3}{*}{ [76] } \\
\hline 29 & R. sorsogonensis & 8 & 0.8 & 8.8 & \\
\hline 30. & R. sundaicus & 4.5 & $0.3-0.8$ & $4.8-5.3$ & \\
\hline
\end{tabular}

Explanation: not described (nd).

\subsection{Structure of Epidermis and Endothecium Cells}

Epidermis. The present study showed that the anther wall in the six $R$. idaeus cultivars studied was composed of four or five cell layers: the epidermis, the endothecium, one 
or two rows of middle layer cells, and the tapetum. A similar structure of the anther wall was described in Agrimonia eupatoria flowers, which had two or three rows of the middle layer and a secretory tapetum [85]. The anther wall is formed through anticlinal and periclinal divisions of the primary parietal cells and those surrounding primary sporogenous cells [86].

In the epidermis cells of the red raspberry stamens, we confirmed the presence of a thick outer cell wall with perpendicular elevations corresponding to cuticle striae or arranged obliquely near the anticlinal wall. The present study and literature data showed that the cuticle exhibited a homogeneously distributed lamellar cuticle proper band and the outer and inner reticulate cuticular layers [87-89]. The epidermal wall was thickened and cutinized. The epidermis cells observed in the present study were smaller than the endothecium cells. In contrast, Watson and Dallwitz [90] reported that cells of all layers visible in the cross-section of the $C$. tanacetifolia anther had a similar size and shape.

Endothecium. A single layer of endothecium cells was observed in the anther wall of the analyzed $R$. idaeus cultivars. The cells of this tissue in other species described in the literature were found to form from one to several layers [91-93]. The endothecium cells in the red raspberry anthers described in the present study radially elongated, which is consistent with data reported by Çetinbaş and Ünal 2015 [94]. These authors found that these cells developed until the anther dehiscence stage.

The endothecium cells of the studied $R$. idaeus cultivars had characteristic thickenings with a semicircular outline on both sides of the anticlinal and periclinal walls. As reported in the literature, already in the tetrad stage, endothecium cell walls had fibrous thickenings enlarging during anther development [94]. Similar evaginations were observed in anticlinal and inner tangential walls of the microsporangial endothecium in Prunus species. The cell walls of the anther connective exhibited characteristic evaginations [95-97].

These characteristic thickenings of the endothecium cell walls found in the present study in $R$. idaeus and described in the literature for other taxa determine the correct mechanism of anther dehiscence [29,30,89]. Endothecium wall thickenings composed of cellulose and lignin are formed after the phase of differentiation of anther cell layers, and this process is strictly dependent on auxins and jasmonic acid $[29,98]$. The action of auxins is regulated by a gene encoding the MYB26 transcription factor in the lignin biosynthesis pathway in cell walls. Lignification occurs simultaneously with the disappearance of middle layer and tapetum cells $[29,99]$. The evagination of secondary cell walls is regulated by the TCP24 gene. The fusion of this gene with the EAR motif repressor domain (SRDX) stimulates the lignification process and, consequently, increases the thickness of the cell wall and regulates anther endothecium development [100].

The endothecium cells of the anther in the examined red raspberry cultivars were strongly vacuolated and had a thin parietal band of cytoplasm and lignified walls with characteristic thickenings. These cells create a fibrous mechanical layer, which generates stress forces leading to anther dehiscence along the stomium. The structure and development of the endothecium differ between the members of the family Rosaceae [98,101,102].

Our study demonstrated that the stamen filament in the R. idaeus cultivars had a round, elliptical, or slightly flattened outline. As shown by literature data, the flattened outline corresponds structurally to the flat stamens in R. adornatus and R. ramachandrae flowers [68]. In the analyzed $R$. idaeus cultivars, as in other species described in the literature, the central part of the filament contains a collateral vascular bundle surrounded by a multi-layer parenchyma tissue and a single epidermis layer [89].

\subsection{Pollen Mass}

The mass of pollen collected from 10 flowers of the biennial and repeated fruiting cultivars (24.8-35.7 and 22.5-28.5, respectively) was higher than the values determined in red raspberry (11 mg/10 flowers) and $R$. fruticisus (14.8 mg/10 flowers) but lower than the amount of pollen produced by $R$. longobaccus (49 mg/10 flowers) [103]. Moreover, the $R$. idaeus pollen mass determined in the present study was higher than in the genus 
Ribes (2-4 mg/10 flowers) and Potentilla (1.4-7.2 mg/10 flowers) and comparable to Rosa (36 mg/10 flowers) [103-105]. The pollen mass in the analyzed cultivars was influenced by climatic conditions, variable air temperature, and varied precipitation rates during the flowering period. Rubus idaeus pollen is highly similar to that of bramble (R. fruticosus L.) in both the pellet color and the microscopic features of individual grains. It is a valuable nutritional source for pollinators. Although raspberry is a self-pollinating plant, crosspollination has a clearly beneficial effect [106-108]. The appropriate selection of compatible pollinators is highly important in mono-varietal cultivation of this species under cover, as it ensures a larger fruit size (by approximately 30\%) and an increased number of seeds in the fruit and, consequently, increased yields [109-111]. Literature data show that the presence of the honeybee in the pollination process is insufficient to achieve the maximum red raspberry yields. In addition to Apis mellifera, Bombus terrestris L. and various Osmia spp. are involved in the pollination of $R$. idaeus in field and greenhouse conditions $[112,113]$.

\subsection{Biologically Active Chemical Compounds}

Protein. The protein content in the pollen of the six R. idaeus cultivars analyzed in this study ranged from $26 \%$ ('Polana') to $31 \%$ ('Laszka'). This range was higher than the level determined in R. fruticosus (15\%) [36] and Rubus sp. (19-24\%) [38-40,114], similar to the protein concentration in pollen grains of $R$. unifolius (26\%) [41], $R$. idaeus var. strigosua (26\%) [35]), and Rubus sp. (28\%) [115,116], and lower than the level detected in R. fructicosus (37\%) [37].

In line with the thesis that the protein content determines the quality of pollen grains [42], the pollen of the analyzed $R$. idaeus cultivars can be regarded as pollen with high quality. Literature data show that high protein concentrations in raspberry pollen increase the frequency of visits by insects, e.g., honeybees. In turn, as shown by Kleinschmidt and Kondos [117], pollen grains containing over $20 \%$ of proteins are attractive for many insect pollinators. Scientific reports indicate that the protein-rich monofloral $R$. idaeus pollen with high nutritional value as well as pollen of many other species from different genera attract insects and enhance their immunity and vitality $[38,118,119]$. In honeybees, $R$. idaeus pollen regulates the expression of genes encoding transferrin and vitellogenin proteins, which are involved in immune reactions as well as influence the behavior and social life of these insects $[38,120,121]$. It has been evidenced that protein-poor pollen reduces the level of vitellogenin in honeybee hemolymph and lowers the insect resistance to diseases $[122,123]$ The synthesis of transferrin, which is a protein responsible for binding and transporting iron from pollen out of the alimentary tract, is also a promising basis for effective fight against the Nosema ceranae parasite living in honeybee guts. This parasite uses honeybee transferrin to uptake iron directly from the pollen for its own purposes. Improvement of the immune function and survival of N. ceranae-infected honeybees can be achieved by reduction of transferrin production and limitation of iron loss [124]. In turn, vitellogenin has antioxidant activity, thus prolonging the life of queens and workers, and is involved in the hormonal regulation of the foraging behavior. The vitellogenin reserves of the nurse bees determine the health of the honeybee colony $[125,126]$.

Amino acids. Fifteen amino acids were identified in the pollen of the studied R. idaeus cultivars. This number was quite similar to that (16-22) recognized in the other species of the family Rosaceae and in pollen baskets with a diverse species composition [127-129]. In the present study, the proportion of exogenous amino acids in the total pool in the $R$. idaeus cultivars was in the range of $33.4-37.2 \%$. This value was lower than in R. fructicosus (46.4-65.5\%) and other species of the subfamily Rosoideae: Agrimonia eupatoria (56.7\%), Filipendula ulmaria (40.8\%), Potentilla anserina (50.6\%), P. reptans (55.7\%), Rosa canina (67.2\%), and Waldsteinia geoides (57.1\%), but higher than in P. erecta $(25 \%)$ [36,37]. Leucine, lysine, and valine as well as phenylalanine, threonine, and isoleucine were the dominant exogenous amino acids recognized in the pollen of the examined red raspberry cultivars. Together with histidine and arginine, they were classified as essential for the development of bees [130]. In the human diet, the so-called hydrophobic branched-chain amino acids 
(BCAAs), i.e., leucine, isoleucine, and valine, constituting approximately $40 \%$ of the pool of endogenous amino acids are highly required [131]. BCAA catabolism is involved in adipocyte metabolism, differentiation, and lipogenesis [132]. Stimulation of BCAA oxidation by consumption of excess leucine markedly reduced isoleucine and valine pools. Isoleucine was recognized as a key regulator of metabolic health and adverse metabolic response to dietary BCAAs. Reducing dietary isoleucine is proposed as a new approach to treating and preventing obesity and diabetes [131,133,134].

In the total pool of amino acids in the pollen of the analyzed $R$. idaeus cultivars, leucine, lysine, and valine accounted for $5.6-9.2 \%, 5.6-8.4 \%$, and $4.7-8.6 \%$, respectively. These compounds serve important metabolic functions. Leucine regulates immune response and lysine acts antivirally. Isoleucine and valine increase the availability of succinyl-CoA and the amount of oxaloacetate and enhance the oxidation of free fatty acids $[135,136]$. Threonine participates in the biosynthesis of the mucin protein, which is necessary for lymphocyte proliferation, and phenylalanine catalyzes the synthesis of neurotransmitters regulating neuronal function and cellular metabolism [135]. The amino acid content in the pollen grains of the biennial and repeated fruiting raspberry cultivars was similar to that proposed in scientific reports as an ideal composition of essential pollen amino acids (arginine 11\%, histidine 5\%, isoleucine $14 \%$, leucine $16 \%$, lysine $11 \%$, methionine $5 \%$, phenylalanine $9 \%$, threonine $11 \%$, tryptophan $4 \%$, valine $14 \%$ ) determined both for the honeybee and other animals [37].

The highest levels of endogenous amino acids in the pollen of the studied R. idaeus cultivars were determined in the case of aspartic acid, glutamic acid, and proline, whereas the detected concentrations of serine and tyrosine were smaller. Aspartic acid accounted for $12.8-17.2 \%$ of the total pool of amino acids. This compound is involved in reproduction and endocrine processes, mainly in testosterone production $[137,138]$. Aspartic acid is an important modulator in the central nervous system. As a signaling molecule, it regulates cytokine production and is a mediator in autoimmune diseases [139]. The concentration of glutamic acid was $12.4-14.6 \%$. Glutamine, serine, and tyrosine act as neurotransmitters [140,141]. Serine is present in the central nervous system and participates in the secretion of hormones in the neuroendocrine and endocrine systems [142]. As a neuromodulator of glutamatergic neurotransmission, this amino acid regulates signal transmission in the cerebral cortex and participates in the process of memorizing and learning $[140,143,144]$. In turn, tyrosine regulates the immune response and cellular metabolism through inhibition of the production of inflammatory cytokines and hydrogen peroxide [141].

The proline content in the pollen of the studied R. idaeus cultivars was $6.5-9.4 \%$. This amino acid together with $\gamma$-aminobutyric acid (GABA) plays a crucial role in sexual reproduction in angiosperms: pollen development, pollination, and pollen tube guidance. Proline biosynthesis during late stages of microspore development and in mature pollen grains determines pollen development and fertility. It serves a signaling function and constitutes a pollen reward for insects. Proline maintains the viability of the protoplast in pollen grains exposed to drying during transport to the stigma and ensures their hydration after reaching the destination $[145,146]$. A high concentration of proline is a marker of pollen sample freshness. Proline is involved in the maintenance of the cellular redox potential, DNA synthesis, and gene expression; it also exhibits antimicrobial activity [147-149].

The endogenous amino acids alanine, arginine, glycine, and histidine were present in a considerable amount in the studied $R$. idaeus pollen. In the human organism, alanine plays a key role in the glucose-alanine cycle. It increases muscle strength and reduces fatigue during physical activity $[150,151]$. Alanine is also a mediator in autoimmune diseases [152]. Glycine is an important component of collagen and keratin. It also supports calcium absorption and reduces stomach acid secretion. It improves nervous system function by supporting memory and concentration and acts as a transmitter in the central nervous system [153-155]. In turn, another amino acid, histidine, mitigates allergic reactions, dilates blood vessels, participates in acetylcholine release, and modulates immune response. It also plays an important role in digestion by releasing gastrin. An important function of 
histidine is protection against UV radiation and metal binding [156]. Serine and alanine increase lymphocyte proliferation. These amino acids as well as arginine, phenylalanine, tyrosine, and proline have antioxidant activity $[38,157,158]$. The concentrations of leucine (6.4-8.7\%), valine (5.7-6.3\%), lysine (6.2-7.9\%), isoleucine (4.8-5.5\%), histidine (2.3-2.7\%), and threonine $(5.0-5.8 \%)$ in the pollen of the analyzed R. idaeus cultivars fully cover the minimum requirements for these amino acids, i.e., 5.9, 3.9, 4.5, 3, 1.5, and 2.3\%, established for humans by Al-Kahtani et al. [129]. This confirms the validity of using pollen in nutrition as a supplementary ingredient.

Lipids. Pollen lipids play a crucial role in sexual reproduction. Fatty acids of membrane lipids are highly required for rapid apical growth of pollen tubes transporting sperm cells into the ovule. The total amount of pollen grain lipids, relative to the pollination type, greatly varies depending on the family [159].

The values of total fat content in the pollen grains of the six R. idaeus cultivars (3.14 'Polka' - 4.36\% 'Radziejowa') were lower than those determined by Di Pasquale et al. [38] in Rubus sp. pollen grains (6.4\%) and in this type of pollen mixed with Castanea and Cistus pollen (1.7-3.0\%) [60]. Moreover, the values obtained in our studies were higher than those in Rubus sp. pollen reported by other researchers (1.31-2.85\%) [115,116]. Literature reports show that the lipid concentration in frozen pollen dominated by Rubus spp. $(89.6 \%)$ was lower $(3.74 \%)$ than in dry pollen grains $(4.39 \%)$ [52,160]. It is believed that entomophilous pollen grains accumulate relatively more storage lipids than wind-pollinated ones [159]. Farah et al. [161] have shown that lipids, primarily saturated and unsaturated fatty acids, glycophospholipids, sphingolipids, sterols, and oxylipids, as well as lipopolysaccharides from the microbiome on the pollen surface can be ligands to allergenic proteins; therefore, they may be responsible for allergic reaction [55].

Fatty acids. In the pollen of the examined $R$. idaeus cultivars, saturated fatty acids (SFAs) accounted for 32.7 ('Polka') - 44.7\% ('Polana') of the total FA pool. These values exceeded the content of these acids, i.e., $25.9,29$, and $29.7 \%$, recorded in samples of pollen from the family Rosaceae with 5.6, 3.1, and $4.4 \%$ of Rubus-type pollen, respectively, and were lower than the level of SFAs (56.9\%) in honeybee pollen with the $4-27.8 \%$ amount of Rubus grains [51,53].

The dominant SFAs in the R. idaeus pollen were palmitic (26.3-33.0\%), stearic (5.1-8.9\%), and behenic acids (0.4-2.1\%). The level of palmitic acid was higher than its value (20.2-22.2\%) in mixtures of pollen samples containing $3.1-5.6 \%$ of Rubus sp. grains. The pollen also contained capric acid (4.2-8.5\%) [53]. In turn, honeybee pollen with a varied composition (e.g., Rubus sp. pollen constituting $4.7-27.8 \%$ ) was dominated by isopalmitic acid (22.3\%), palmitic acid $(16.4 \%)$, tridecanoid acid $(1.8 \%)$, and lauric acid $(0.4 \%)$. The content of monounsaturated fatty acids (MUFAs) was $14.6 \%$, and polyunsaturated fatty acids (PUFAs) accounted for $32.4 \%$ of the sum of all fatty acids [51].

The total content of unsaturated fatty acids (USFAs) in the pollen of the analyzed raspberry cultivars versus the total fatty acid content was $37.7-56.1 \%$. The range of these values was similar or within the concentration range of this group of fatty acids (49.6-58.6\%) in a mixture of pollen samples with the confirmed presence of nine botanical families [53]. Bashir et al. [162] claims that the presence and abundance of USFAs varies markedly among different species and even varieties. This was confirmed by the presence of $\alpha$-linolenic acid in 'Glen Ample' and 'Laszka', which was not detected in the other cultivars. In the present study, the red raspberry pollen did not contain very-long-chain fatty acids (C20-C22), except cis-13,16-docosadienoic acid. Similarly, these acids were not detected by Hernández et al. [159] in Olea europaea L., although they were contained in the pollen grain of other oleaginous species, such as rapeseed, oil palm, and sunflower [163]. It is believed that PUFAs are precursors of the synthesis of volatile compounds, which attract pollinators. This thesis seems to be confirmed by the low degree of unsaturation of pollen grains of the six red raspberry cultivars analyzed in this study and olive pollen [159], since both of these species are insect-pollinated. However, the pollen fatty acid content and composition greatly fluctuate depending on the genotype. 
In the present study, MUFAs in the pollen of the six $R$. idaeus cultivars were dominated by palmitoleic acid (2.3-3.7\%) as well as oleic and elaidic acids (28.3-44.4\%), whereas PUFAs were mostly represented by cis-13,16-docosahexaenoic acid $(0.2-0.7 \%)$ as well as linoleic and linoelaidic acids (3.2-5.5\%). Feás et al. [53] identified oleic and eicosenoic acids among MUFAs, while linoleic and $\alpha$-linolenic acids were the dominant PUFAs. In honeybee pollen, the former group was dominated by oleic and margaroleic acids, whereas linolenic and linoleic acids dominated in the latter group [51]. Linoleic acid was the main polyunsaturated fatty acid in pollen lipids in 6 grass species, 2 weed species, and 14 tree species [162]. Myristic, palmitic, stearic, oleic, linolenic, and arachidic acids present in pollen are important for the apiculture sector. Linoleic acid inhibited the growth of harmful pathogens Paenibacillus larva and Melissococcus plutonius. Myristic, linolenic, and oleic acids have been found to enhance pollen quality in the redgum (Corymbia calophylla) and improve honeybee longevity $[54,164]$. Fatty acids are an important component of functional food with multifarious health-promoting effects [16,165].

Minerals. In this study, in addition to organogens, the presence of potassium, phosphorus, sulfur, calcium, manganese, chlorine, and magnesium was detected in the exine of the pollen grains of the six raspberry cultivars. The mineral composition of pollen grains determines their further development and nutritional value [166]. Calcium is recognized as a critical element that is strongly related to pollen germination and pollen tube growth as well as interactions between pollen tubes and pistil cells [167]. The role of calcium in the pollen tube growth consists in regulation of cell growth, vesicular transport, and intracellular signaling by localized gradients of second messengers and regulation of ion channels in pollen by calcium-dependent kinases [168].

Phosphorus affects the production and size of pollen grains, pollen reproductive performance, and pollen tube growth rate $[169,170]$. Potassium and chlorine channels play a crucial role in all aspects of osmolarity and are responsible for numerous other functions in plants, including sexual reproduction. Activation of $\mathrm{K}^{+}$and $\mathrm{Cl}^{-}$release with the contribution of NPPB ((5-nitro-2-(3-phenylpropylamino) benzoic acid), TEA (tetraethylammonium chloride), and $\mathrm{Ba}^{2+}$-sensitive plasmalemma ion channels has key importance for the initiation of pollen germination and regulation of pollen tube growth via regulation of turgor pressure, membrane potential, and water uptake in the pollen tube [171-173].

Manganese also plays an important role in pollen germination and pollen tube growth. As reported by Sawidis et al. [174], the presence of low concentrations of manganese $\left(10^{-12}-10^{-10} \mathrm{M}\right)$ stimulated pollen germination, whereas high concentrations $\left(>10^{-8} \mathrm{M}\right)$ inhibited this process. Excess of manganese was believed to cause morphological anomalies, irregular pollen tube thickening, and tip swelling during tube growth. The main effect was the anomalous cell wall formation at the tip, in which the presence of several organelles reduced the number of secretory vesicles, and a loose network of fibrillar material and spherical aggregates, mostly in the tip region; this material was progressively loosened into the surrounding medium.

A key role in the development of pollen is played by magnesium. Among the $\mathrm{Mg}^{2+}$ transporting MGT proteins, the AtMGT5 group located in anther mitochondria acts as a bifunctional transporter. It participates in the transport of $\mathrm{Mg}^{2+}$ ions between the cytosol and mitochondria in plant gametogenesis. Magnesium Transporter 5 (MGT5) plays an important role in $\mathrm{Mg}$ transport from the tapetum to the microspore [175-178]. The essential role of the magnesium transporters in the pollen development process has been demonstrated. Slow development is believed to be a general mechanism to restore $m g t$ f fertility, which allows other redundant magnesium transporter (MGT) members to transport sufficient $\mathrm{Mg}$ for pollen formation [179].

The knowledge of the mineral composition in pollen is especially important when the pollen is used to supplement human or bee diet. The content of individual elements may vary considerably. Some pollen is potassium deficient, whereas some contains very high concentrations of potassium and sodium [57,180]. Potassium and phosphorus are required for the proper growth of a bee colony; on the other hand, their excess may lead to paralysis 
of adult insects. In turn, high concentrations of zinc may be a cause of colony collapse disorder and, consequently, adult worker bees leaving the hive unprotected [57,181-183].

The present results may be useful not only for specialists in plant biology, agriculture, horticulture, and health sciences, but also for a wider audience interested in functional food, nutraceuticals, and nutracosmetics. This knowledge can help raspberry growers to understand the importance of pollen reward for pollinators as a factor increasing fruit yields. These data may also be helpful in cultivation work aimed at the production of new cultivars with high quality traits and the production of pollen as a nutritional and pharmaceutical ingredient. This information can have practical applications in apiculture and apitherapy. The data are also important for manufacturers using natural bee products in food, pharmaceutical, and cosmetic industries and for consumers.

The target in future research should be determination of the pharmacological properties of $R$. idaeus pollen, e.g., its antiallergic, antioxidant, anti-inflammatory, and detoxifying effects, and the potential application of this product in phytotherapy, molecular pharmacology, and nanotechnology. The antioxidant activity of pollen has been shown to be species-specific; therefore, it should be defined more precisely. Moreover, the assessment of pollen activity should be combined with evaluation of characteristic predictive biomarkers. Research on the standardization of the quality of pollen from individual species is recommended to determine the optimal composition of blends of pollen from various taxa in terms of biological activity, placing emphasis on the potential occurrence of allergic reactions. Furthermore, due to the growing interest in the therapeutic properties of pollen, it is necessary to develop and validate new methods for determination of its chemical composition and procedures for the detection of microbial contaminants, which can be a potential source of mycotoxins. It is also important to check the presence of pollen from transgenic plants in honeybee products and recognize potential side effects of such pollen on human health. Further research is needed to develop reliable methods of using pollen grains for micro- and nano-encapsulation. Additionally, analyses of the suitability of single-species pollen as a food product and ingredient of functional food or pharmaceutical and cosmetic recipes are recommended, taking into account standardization and safety of use.

\section{Conclusions}

As demonstrated in the present study, the striated cuticle ornamentation of the anther epidermis with the arcuate, semicircular, or loop-like outline of the striae and their parallel arrangement arcuate shape in both directions on the filaments may constitute auxiliary signs in the phylogenesis and taxonomy of related species in this genus. The ultrastructural study of the anther epidermis showed a thick outer cell wall with elevations corresponding to cuticle striae and a homogeneous cuticle band with the lamella proper and an outer and inner reticulate layer. Radially elongated endothecium cells with perpendicular and semicircular evaginations arranged in series increased the lignification and thickness of the wall and formed a mechanical layer generating bending forces involved in stomium rupture. The characteristic traits of the stamen structure represent new data in the biology of the generative organs. In the flowers of the studied raspberry cultivars, the mean number of stamens in a single flower in the biennial fruiting group and in the repeated fruiting cultivars was 102 'Glen Ample'-113 'Laszka' and 93 'Polka'-112 'Polana', respectively. In terms of the mass of pollen produced by 10 flowers, the cultivars were ranked as follows: 'Pokusa' <'Polana' <'Glen Ample' < 'Polka' < 'Radziejowa' < 'Laszka'. In terms of the total protein content in pollen, the following order of the cultivars was determined: 'Polana' $<$ 'Polka' < 'Glen Ample' < 'Pokusa' < 'Radziejowa' < 'Laszka'. The content of exogenous amino acids, with the greatest amounts of leucine, lysine, valine, and isoleucine in the total pool, was in the range from $32.7 \%$ 'Polka' to $38.8 \%$ 'Radziejowa'. The branched-chain amino acids are especially important in the human diet. Aspartic acid, glutamic acid, and proline were the endogenous amino acids present most abundantly. The proportion of MUFAs and PUFAs in the pollen of the examined cultivars in relation to the total sum of fatty acids was $32-47 \%$ and $3.7-9.1 \%$, respectively. Myristic, palmitic, and stearic acids were the 
dominant SFAs. The MUFA group was dominated by palmitoleic, oleic, and elaidic acids, whereas cis-13,16-docosahexaenoic, linoleic, and linoleic acids were the most abundant PUFA. Aside from cis-13,16-docosadienoic acid, no very-long-chain fatty acids (C20-C22) were identified in the pollen. The qualitative and quantitative composition of amino acids and fatty acids indicates good quality of pollen grains, increasing the attractiveness of raspberry flowers to insects. In addition to organogenous elements, the exine of the examined cultivars contained potassium, phosphorus, sulfur, calcium, manganese, chlorine, and magnesium. The elemental composition determines the further development of the grains and their nutritional value. It should be emphasized that in the era of the increasing commercial production of $R$. idaeus, the analyzed cultivars provide pollinators, mainly bees and bumblebees, with food of good quality and high attractiveness for a long time (from May to August). These cultivars can be planted in horticultural ecosystems for commercial production to increase the species entomophilic diversity, thereby increasing the fruit yield substantially. Concurrently, the growing demand for raspberry fruit prompts farmers to look for cultivars with high nutritional and commercial value. The pollen of the examined cultivars, which are well acclimatized to moderate climate conditions, may enrich genetic diversity, transferring stable fruit quality traits and resistance necessary in commercial plantations cultivated in variable climatic conditions.

Author Contributions: Conceptualization, M.C. and M.K.; designed the experiments M.C. and M.K.; methodology, M.C. and M.K.; investigation, M.K. and M.C.; graphic design, M.C. and M.K.; statistical analysis, M.K.; writing-original draft preparation, M.C. and M.K.; supervision, M.C. Both authors have read and agreed to the published version of the manuscript.

Funding: This research received no external funding.

Institutional Review Board Statement: Not applicable.

Informed Consent Statement: Not applicable.

Data Availability Statement: Not applicable.

Conflicts of Interest: Authors declare that there are no conflicts of interest.

\section{References}

1. Lebedev, V.G.; Subbotina, N.M.; Maluchenko, O.P.; Krutovsky, K.V.; Shestibratov, K.A. Assessment of genetic diversity in differently colored raspberry cultivars using SSR markers located in flavonoid biosynthesis genes. Agronomy 2019, 9, 518. [CrossRef]

2. Pinczinger, D.; Reth, M.V.; Keilwagen, J.; Berner, T.; Peil, A.; Flachowsky, H.; Emeriewen, O.F. Mapping of the waxy bloom gene in 'Black Jewel' in a parental linkage map of 'Black Jewel' $\times$ 'Glen Ample' (Rubus) interspecific population. Agronomy 2020, 10, 1579. [CrossRef]

3. Khadgi, A.; Weber, C.A. RNA-Seq analysis of prickled and prickle-free epidermis provides insight into the genetics of prickle development in red raspberry (Rubus ideaus L.). Agronomy 2020, 10, 1904. [CrossRef]

4. Khadgi, A.; Weber, C.A. Genome-wide association study (GWAS) for examining the genomics controlling prickle production in red raspberry (Rubus idaeus L.). Agronomy 2021, 11, 27. [CrossRef]

5. FAO. Food and Agriculture Organization of the United Nations. 2019. Available online: http://www.fao.org/faostat/en/\#data/ QC (accessed on 24 April 2021).

6. Heide, O.M.; Sønsteby, A. Physiology of flowering and dormancy regulation in annual-and biennial-fruiting red raspberry (Rubus idaeus L.)—A review. J. Hortic. Sci. Biotechnol. 2011, 86, 433-442. [CrossRef]

7. Sønsteby, A.; Stavang, J.A.; Heide, O.M. Production of high-yielding raspberry long canes: The way to $3 \mathrm{~kg}$ of fruit per cane. J. Hortic. Sci. Biotechnol. 2013, 88, 591-599. [CrossRef]

8. Schmidt, K.; Filep, R.; Orosz-Kovács, Z.; Farkas, Á. Patterns of nectar and pollen presentation influence the attractiveness of four raspberry and blackberry cultivars to pollinators. J. Hortic. Sci. Biotech. 2015, 90, 47-56. [CrossRef]

9. Campos, M.G.R.; Frigerio, C.; Lopes, J.; Bogdanov, S. What is the future of bee-pollen. J. ApiProd. ApiMed. Sci. 2010, 2, 131-144. [CrossRef]

10. Abouda, Z.; Zerdani, I.; Kalalou, I.; Faid, M.; Ahami, M.T. The antibacterial activity of moroccan bee bread and bee-pollen (fresh and dried) against pathogenic bacteria. Res. J. Microbiol. 2011, 6, 376-384.

11. Conte, P.; Del Caro, A.; Balestra, F.; Piga, A.; Fadda, C. Bee pollen as a functional ingredient in gluten-free bread: A physicalchemical, technological and sensory approach. LWT Food Sci. Technol. 2018, 90, 1-7. [CrossRef] 
12. Kudrik, B.T.; Tykhonov, O.I.; Koval, V.M.; Shpychak, O.S.; Rudenko, V.V. Development of the composition of foamy washing liquid with an extract of pollen for use in pediatrics. J. Pharm. Sci. Res. 2018, 10, 1017-1021.

13. Lale, S.V.; Gill, H.S. Pollen grains as a novel microcarrier for oral delivery of proteins. Int. J. Pharm. 2018, 552, 352-359. [CrossRef] [PubMed]

14. Scott, R.J.; Spielman, M.; Dickinson, H.G. Stamen structure and function. Plant Cell. 2004, 16, S46-S60. [CrossRef]

15. García, C.C.; Nepi, M.; Pacini, E. It is a matter of timing: Asynchrony during pollen development and its consequences on pollen performance in angiosperms-A review. Protoplasma 2017, 254, 57-73. [CrossRef]

16. Kostić, A.Ž.; Milinčić, D.D.; Barać, M.B.; Ali Shariati, M.; Tešić, Ž.L.; Pešić, M.B. The application of pollen as a functional food and feed ingredient-The present and perspectives. Biomolecules 2020, 10, 84. [CrossRef] [PubMed]

17. Halbritter, H.; Ulrich, S.; Grímsson, F.; Weber, M.; Zetter, R.; Hesse, M.; Buchner, R.; Svojtka, M.; Frosch-Radivo, A. Pollen morphology and ultrastructure. In Illustrated Pollen Terminology, 2nd ed.; Springer: Cham, Switzerland, 2018; pp. 37-65. [CrossRef]

18. Kostryco, M.; Chwil, M.; Matraszek-Gawron, R. Comparison of the micromorphology and ultrastructure of pollen grains of selected Rubus idaeus L. cultivars grown in commercial plantation. Plants 2020, 9, 1194. [CrossRef] [PubMed]

19. Rezanejad, F. The structure and ultrastructure of anther epidermis and pollen in Lagerstroemia indica L. (Lythraceae) in response to air pollution. Turk. J. Botany 2008, 32, 35-42.

20. Pollard, M.; Beisson, F.; Li, Y.; Ohlrogge, J.B. Building lipid barriers: Biosynthesis of cutin and suberin. Trends Plant Sci. 2008, 13, 236-246. [CrossRef]

21. Samuels, L.; Kunst, L.; Jetter, R. Sealing plant surfaces: Cuticular wax formation by epidermal cells. Annu. Rev. Plant Biol. 2008, 59, 683-707. [CrossRef]

22. Beisson, F.; Li-Beisson, Y.; Pollard, M. Solving the puzzles of cutin and suberin polymer biosynthesis. Curr. Opin. Plant Biol. 2012, 15, 329-337. [CrossRef]

23. Tian, Y.; Xiao, S.; Liu, J.; Somaratne, Y.; Zhang, H.; Wang, M.; Zhang, H.; Zhao, L.; Chen, H. Male STERILE6021 (MS6021) is required for the development of anther cuticle and pollen exine in maize. Sci. Rep. 2017, 7, 16736. [CrossRef]

24. Somaratne, Y.; Tian, Y.; Zhang, H.; Wang, M.; Huo, Y.; Cao, F.; Zhao, L.; Chen, H. Abnormal pollen vacuolation1 (APV1) is required for male fertility by contributing to anther cuticle and pollen exine formation in maize. Plant J. 2017, 90, 96-110. [CrossRef] [PubMed]

25. Xu, D.; Qu, S.; Tucker, M.R.; Zhang, D.; Liang, W.; Shi, J. Ostkpr1 functions in anther cuticle development and pollen wall formation in rice. BMC Plant Biol. 2019, 19, 104. [CrossRef] [PubMed]

26. Chang, Z.; Chen, Z.; Yan, W.; Xie, G.; Lu, J.; Wang, N.; Lu, Q.; Yao, N.; Yang, G.; Xia, J.; et al. An ABC transporter, OsABCG26, is required for anther cuticle and pollen exine formation and pollen-pistil interactions in rice. Plant Sci. 2016, 253, 21-30. [CrossRef] [PubMed]

27. Chang, Z.; Jin, M.; Yan, W.; Chen, H.; Qiu, S.; Fu, S.; Xia, J.; Liu, Y.; Chen, Z.; Wu, J.; et al. The ATP-binding cassette (ABC) transporter OsABCG3 is essential for pollen development in rice. Rice 2018, 11, 58. [CrossRef] [PubMed]

28. Chen, X.; Zhang, H.; Sun, H.; Luo, H.; Zhao, L.; Dong, Z.; Yan, C.Z.; Liu, R.; Chunyan, X.; Li, S.; et al. Irregular pollen exine is a novel factor in anther cuticle and pollen exine formation. Plant Physiol. 2017, 173, 307-325. [CrossRef] [PubMed]

29. Cecchetti, V.; Altamura, M.M.; Brunetti, P.; Petrocelli, V.; Falasca, G.; Ljung, K.; Costantino, P.; Cardarelli, M. Auxin controls Arabidopsis anther dehiscence by regulating endothecium lignification and jasmonic acid biosynthesis. Plant J. 2013, 74, 411-422 [CrossRef] [PubMed]

30. Jung, K.W.; Kim, Y.Y.; Yoo, K.S.; Ok, S.H.; Cui, M.H.; Jeong, B.C.; Yoo, S.D.; Jeung, J.U.; Shin, J.S. A cystathionine- $\beta$-synthase domain-containing protein, CBSX2, regulates endothecial secondary cell wall thickening in anther development. Plant Cell Physiol. 2013, 54, 195-208. [CrossRef] [PubMed]

31. Yang, C.; Xu, Z.; Song, J.; Conner, K.; Vizcay Barrena, G.; Wilson, Z.A. Arabidopsis MYB26/MALE STERILE35 regulates secondary thickening in the endothecium and is essential for anther dehiscence. Plant Cell 2007, 19, 534-548. [CrossRef]

32. Yang, C.; Song, J.; Ferguson, A.C.; Klisch, D.; Simpson, K.; Mo, R.; Taylor, B.; Mitsuda, N.; Wilson, Z.A. Transcription factor MYB26 is key to spatial specificity in anther secondary thickening formation. Plant Physiol. 2017, 175, 333-350. [CrossRef]

33. Jung, K.W.; Oh, S.I.; Kim, Y.Y.; Yoo, K.S.; Cui, M.H.; Shin, J.S. Arabidopsis histidine-containing phosphotransfer factor 4 (AHP4) negatively regulates secondary wall thickening of the anther endothecium during flowering. Mol. Cells 2008, 25, 294-300. [PubMed]

34. Zhao, S.Q.; Li, W.C.; Zhang, Y.; Tidy, A.C.; Wilson, Z.A. Knockdown of Arabidopsis root UVB SENSITIVE4 disrupts anther dehiscence by suppressing secondary thickening in the endothecium. Plant Cell Physiol. 2019, 60, 2293-2306. [CrossRef] [PubMed]

35. Pernal, S.F.; Currie, R.W. The influence of pollen quality on foraging behavior in honeybees (Apis mellifera L.). Behav. Ecol. Sociobiol. 2001, 51, 53-68. [CrossRef]

36. Hanley, M.E.; Franco, M.; Pichon, S.; Darvill, B.; Goulson, D. Breeding system, pollinator choice and variation in pollen quality in British herbaceous plants. Funct. Ecol. 2008, 22, 592-598. [CrossRef]

37. Weiner, C.N.; Hilpert, A.; Werner, M.; Linsenmair, K.E.; Blüthgen, N. Pollen amino acids and flower specialisation in solitary bees. Apidologie 2010, 41, 476-487. [CrossRef]

38. Di Pasquale, G.; Salignon, M.; Le Conte, Y.; Belzunces, L.P.; Decourtye, A.; Kretzschmar, A.; Suchail, S.; Brunet, J.L.; Alaux, C. Influence of pollen nutrition on honey bee health: Do pollen quality and diversity matter? PLoS ONE 2013, 8, e72016. [CrossRef] [PubMed] 
39. Vanderplanck, M.; Leroy, B.; Wathelet, B.; Wattiez, R.; Michez, D. Standardized protocol to evaluate pollen polypeptides as bee food source. Apidologie 2014, 45, 192-204. [CrossRef]

40. Conti, I.; Medrzycki, P.; Argenti, C.; Meloni, M.; Vecchione, V.; Boi, M.; Mariotti, M.G. Sugar and protein content in different monofloral pollens-building a database. Bull. Insectol. 2016, 69, 318-320.

41. Liolios, V.; Tananaki, C.; Dimou, M.; Kanelis, D.; Goras, G.; Kazrazafiris, E.; Thrasuvoulou, A. Ranking pollen from bee plants according to their protein contribution to honey bees. J. Apic. Res. 2016, 54, 582-592. [CrossRef]

42. Roulston, T.A.H.; Cane, J.H.; Buchmann, S.L. What governs protein content of pollen: Pollinator preferences, pollen-pistil interactions, or phylogeny? Ecol. Monogr. 2000, 70, 617-643. [CrossRef]

43. Heslop-Harrison, J.; Haslop-Harrison, Y.; Knox, R.B.; Howlett, B. Pollen-wall proteins: 'gametophytic' and 'sporophytic' fractions in the pollen walls of the Malvaceae. Ann. Bot. 1973, 37, 403-412. [CrossRef]

44. Heslop-Harrison, Y. Pollen germination and pollen tube growth. Int. Rev. Cytol. 1987, 107, 1-78. [CrossRef]

45. Dickinson, H.G.; Elleman, C.J.; Doughty, J. Pollen coatings-Chimaeric genetics and new functions. Sex. Plant Reprod. 2000, 12, 302-309. [CrossRef]

46. Obermeyer, G.; Kriechbaumer, R.; Strasser, D.; Maschessing, A.; Bentrup, F.W. Boric acid stymulates the plasma membrane $\mathrm{H}^{+}$ ATPase of ungerminated lily pollen grains. Physiol. Plant. 1996, 98, 281-290. [CrossRef]

47. Pertl, H.; Himly, M.; Gehwolf, R.; Kriechbaumer, R.; Strasser, D.; Michalke, W.; Obermeyer, G. Molecular and physiological characterisation of a 14-3-3 protein from lily pollen grains regulating the activity of the plasma membrane $\mathrm{H}^{+} \mathrm{ATPase}$ during pollen grain germination and tube growth. Planta 2001, 213, 132-141. [CrossRef] [PubMed]

48. Scolari, L.M.; Hancock, R.D.; Hedley, P.E.; Morris, J.; Smith, K.; Graham, J. Combining QTL mapping and gene expression analysis to elucidate the genetic control of 'crumbly' fruit in red raspberry (Rubus idaeus L.). Agronomy 2021, 11, 794. [CrossRef]

49. Cook, S.M.; Awmack, C.S.; Murray, D.A.; Williams, I.H. Are honey bees' foraging preferences affected by pollen amino acid composition? Ecol. Entomol. 2003, 28, 622-627. [CrossRef]

50. Paramás, A.M.; Bárez, J.A.; Marcos, C.C.; García-Villanova, R.J.; Sánchez, J.S. HPLC-fluorimetric method for analysis of amino acids in products of the hive (honey and bee-pollen). Food Chem. 2006, 95, 148-156. [CrossRef]

51. Saa-Otero, M.P.; Diaz-Losada, E.; Fernandez-Gomez, E. Analysis of fatty acids, proteins and ethereal extract in honeybee pollen-considerations of their floral origin. Grana 2000, 39, 175-181. [CrossRef]

52. Estevinho, L.M.; Dias, T.; Anjos, O. Influence of the storage conditions (frozen vs. dried) in health-related lipid indexes and antioxidants of bee pollen. Eur. J. Lipid Sci. Technol 2019, 121, 1800393. [CrossRef]

53. Feás, X.; Vázquez-Tato, M.P.; Estevinho, L.; Seijas, J.A.; Iglesias, A. Organic bee pollen: Botanical origin, nutritional value, bioactive compounds, antioxidant activity and microbiological quality. Molecules 2012, 17, 8359-8377. [CrossRef] [PubMed]

54. Manning, R. Fatty acids in pollen: A review of their importance for honey bees. Bee World 2001, 82, 60-75. [CrossRef]

55. Dahl, Å. Pollen lipids can play a role in allergic airway inflammation. Front. Immunol. 2018, 9, 2816. [CrossRef]

56. Yang, K.; Wu, D.; Ye, X.; Liu, D.; Chen, J.; Sun, P.L. Characterization of chemical composition of bee pollen in China. J. Agric. Food Chem. 2013, 61, 708-718. [CrossRef] [PubMed]

57. Kostić, A.Ž.; Pešić, M.B.; Mosić, M.D.; Dojčinović, B.P.; Natić, M.M.; Trifković, J.Đ. Mineral content of bee pollen from Serbia. Arh. Hig. Rada Toksikol. 2015, 66, 251-258. [CrossRef] [PubMed]

58. Fratini, F.; Turchi, B.; Michele, G.; Torracca, B.; Giusti, M.; Sagona, S.; Felicioli, A.; Cerri, D. Bee-gathered pollen loads suspension: Preliminary assessment of interaction with microbial growth for a potential employment as a natural food additive. J. Microbiol. Biotech. Food Sci. 2014, 3, 467-469.

59. Mărgăoan, R.; Mărghitaş, L.A.; Dezmirean, D.S.; Dulf, F.V.; Bunea, A.; Socaci, S.A.; Bobiş, O. Predominant and secondary pollen botanical origins influence the carotenoid and fatty acid profile in fresh honeybee-collected pollen. J. Agric. Food Chem. 2014, 62, 6306-6316. [CrossRef] [PubMed]

60. Li, Q.Q.; Wang, K.; Marcucci, M.C.; Sawaya, A.C.H.F.; Hu, L.; Xue, X.F.; Hu, F.L. Nutrient-rich bee pollen: A treasure trove of active natural metabolites. J. Funct. Foods 2018, 49, 472-484. [CrossRef]

61. Barbieri, D.; Gabriele, M.; Summa, M.; Colosimo, R.; Leonardi, D.; Domenici, V.; Pucci, L. Antioxidant, nutraceutical properties, and fluorescence spectral profiles of bee pollen samples from different botanical origins. Antioxidants 2020, 9, 1001. [CrossRef]

62. Reynolds, E.S. The use of lead citrate at high $\mathrm{pH}$ as an electron opaque stain in electron microscopy. J. Cell Biol. 1963, 17, 208-212. [CrossRef] [PubMed]

63. Warakomska, Z. Badania nad wydajnościa pyłkową roślin/Studies on the pollen efficiency of plants (in Polish). Pszczeln. Zesz. Nauk. 1972, 16, 63-90.

64. Polish Standard PN-EN ISO 12966-1. Animal and Vegetable Fats and Oils. Gas Chromatography of Fatty Acis Methyl Esters. Part 1: Guidelines on Modern Gas Chromatography of Fatty Acid Methyl Esters (ISO 12966-1: 2014); ISO: Geneva, Switzerland, 2014.

65. Wierciński, J. Przewodnik do Ćwiczeń z Instrumentalnej Analizy Chemicznych Składników Żywności. / Guidebook for Classes in Instrumental Analysis of Food Chemical Components for Students of Food Technology and Human Nutrition, 1st ed.; Wydawnictwo Akademii Rolniczej: Lublin, Poland, 1999; p. 137. (in Polish)

66. Rabie, A.L.; Wells, J.D.; Dent, L.K. The nitrogen content of pollen protein. J. Apic. Res. 1983, 22, 119-123. [CrossRef]

67. Davies, M.G.; Thomas, A.J. An investigation of hydrolytic techniques for the amino acid analysis of foodstuffs. J. Sci. Food Agric. 1973, 24, 1525-1540. [CrossRef]

68. Gupta, C.; Dash, S.S. A new species of Rubus (Rosaceae) from Arunachal Pradesh, India. Blumea 2018, 63, 26-30. [CrossRef] 
69. San, A.M.; Linn, S.S.; Aye, S.M. Taxonomy and pollen morphology of the family Rosaceae found in the southern and nothern Shan state. J. Myanmar Acad. Arts Sci. 2019, 27, 189-210.

70. Goldberg, R.B.; Beals, T.P.; Sanders, P.M. Anther development: Basic principles and practical applications. Plant Cell 1993, 5, 1217-1229. [CrossRef]

71. Skrzydeł, J.; Borowska-Wykręt, D.; Kwiatkowska, D. Structure, assembly and function of cuticle from mechanical perspective with special focus on perianth. Int. J. Mol. Sci. 2021, 22, 4160. [CrossRef] [PubMed]

72. Yang, X.; Wu, D.I.; Shi, J.; He, Y.I.; Pinot, F.; Grausem, B.; Yin, C.; Zhu, L.; Chen, M.; Luo, Z.; et al. Rice CYP703A3, a cytochrome P450 hydroxylase is essential for development of anther cuticle and pollen exine. J. Integr. Plant Biol. 2014, 56, 979-994. [CrossRef] [PubMed]

73. Endress, P.K.; Stumpf, S. The diversity of stamen structures in 'lower' Rosidae (Rosales, Fabales, Proteales, Sapindales). Bot. J. Linn. Soc. 1991, 107, 217-293. [CrossRef]

74. Nikolić, D.; Radović, A. The morphological properties of the flower and the percent of fertilised pistils of promising yellow fruiting raspberry hybrids. In International Scientific Symposium of Agriculture "AGROSYM Jahorina 2011", Sarajevo, November 10-12 2011; Kovečević, D., Ed.; Faculty of Agriculture: East Sarajevo, Bosnia and Herzegovina, 2011; pp. $165-171$.

75. Orzeł, A.; Bieniasz, M.; Małodobry, M. Biology of flowering species of the genus Rubus as a preliminary study in primocane fruiting blackberries. In XI International Rubus and Ribes Symposium 1133; Fernandez, G.E., Hummer, K.E., Eds.; ISHS: Leuven, Belgium, 2016; pp. 171-176. [CrossRef]

76. Kalkman, C. The Genus Rubus (Rosaceae) in Malesia. 2. The subgenus Micranthobatus. Blumea-Biodivers. Evol. Biogeogr. Plants 1984, 29, 319-386.

77. Kalkman, C. The genus Rubus (Rosaceae) in Malesia. 3. The subgenus Micranthobatus. Blumea-Biodivers. Evol. Biogeogr. Plants 1987, 32, 323-341.

78. Nybom, H. Pollen-limited seed set in pseudogamous blackberries (Rubus L. subgen. Rubus). Oecologia 1987, 72, 562-568. [CrossRef] [PubMed]

79. Bean, A.R. Revision of Rubus subgenus Micranthobatus (Fritsch) Kalkman (Rosaceae) in Australia. Austrobaileya 1995, 4, 321-328.

80. Hiregoudar, H.; Manju, D.; Nautiyal, B.P. Floral biology of wild raspberry (Rubus macilentus C.) species of Garhwal Himalaya, Uttarakhand, India. IJCS 2019, 7, 2200-2206.

81. Gupta, C.; Dash, S.S. Rubus sengorensis (Rosaceae): A new record to India from Arunachal Pradesh. Nelumbo 2015, 57, 50-55. [CrossRef]

82. Normasiwi, S.; Salamah, A.; Surya, M.I. Morphological characteristics of Indonesian Rubus flowers. Biodiversitas 2021, 22, 1441-1447. [CrossRef]

83. Camarda, I. Rubus laconensis and Rubus pignatti (Rosaceae), two new species from Sardinia (Italy). Plant Biosyst. 2013, 147, 849-856. [CrossRef]

84. Brown, A.O.; McNeil, J.N. Pollination ecology of the high latitude, dioecious cloudberry (Rubus chamaemorus; Rosaceae). Am. J. Bot. 2009, 96, 1096-1107. [CrossRef] [PubMed]

85. Saffari, P.; Majd, A.; Jonoubi, P.; Najafi, F. Study on the reproductive organs development and embryological features of Agrimonia eupatoria L. (Rosaceae). Bot. Lett. 2021, 168, 270-282. [CrossRef]

86. Raghavan, V. Anther and pollen development in rice (Oryza sativa). Am. J. Bot. 1988, 75, 183-196. [CrossRef]

87. Jeffree, C.E. The fine structure of the plant cuticle. Annu. Plant Rev. 2006, 23, 11-125.

88. Evert, R.F. Esau's Plant Anatomy. Meristems, Cells and Tissues of the Plant Body-their Structure, Function and Development, 3rd ed.; John Wiely and Sons Inc.: Hoboken, NJ, USA, 2007; p. 624.

89. De Carvalho, J.D.T.D.; Oliveira, J.M.S.D.; Freitas, C.C.D.; Martins, M.S. Stamen 1144 morphoanatomy of Dyckia Schult. f. (Bromeliaceae, Pitcairnioideae) species: New data 1145 for taxonomic use. Acta Bot. Bras. 2016, 30, 389-400. [CrossRef]

90. Watson, L.; Dallwitz, M.J. The families of angiosperms: Automated descriptions with interactive identification and information retrieval. Aust. Syst. Bot. 1992, 4, 681-695. [CrossRef]

91. Bhanwra, R.K.; Vij, S.P.; Chandel, V.; Dutt, R.; Dutt, S. Development of pollinium in two epidendroid orchids. Curr. Sci. 2006, 90, 1384-1388.

92. Nelson, M.R.; Band, L.R.; Dyson, R.J.; Lessinnes, T.; Wells, D.M.; Yang, C.; Everitt, N.M.; Jensen, O.E.; Wilson, Z.A. A biomechanical model of anther opening reveals the roles of dehydration and secondary thickening. New Phytol. 2012, 196, 1030-1037. [CrossRef]

93. Xue, J.S.; Yao, C.; Xu, Q.L.; Sui, C.X.; Jia, X.L.; Hu, W.J.; Lv, Y.L.; Feng, Y.F.; Peng, Y.J.; Shen, S.Y.; et al. Development of the middle layer in the anther of Arabidopsis. Front. Plant Sci. 2021, 12, 634114. [CrossRef] [PubMed]

94. Çetinbaş, A.; Ünal, M. Developmental and cytochemical features of male reproductive organ in Crataegus tanacetifolia (Lam). Pers. Not. Bot. Horti Agrobo. 2015, 43, 507-514. [CrossRef]

95. Hufford, L.D.; Endress, P.K. The diversity of anther structures and dehiscence patterns among Hamamelididae. Bot. J. Linn. Soc. 1989, 99, 301-346. [CrossRef]

96. D'Arcy, W.G. Anthers and stamens and what they do. In The Anther: Form. Function and Phylogeny, 1st ed.; D'Arcy, W.G., Keating, R.C., Eds.; Cambridge University Press: Cambridge, UK, 1996; pp. 1-24.

97. Reinoso, H.; Luna, V.; Pharis, R.P.; Bottini, R. Dormancy in peach (Prunus persica) flower buds. V. Anatomy of bud development in relation to phenological stage. Can. J. Bot. 2002, 80, 656-663. [CrossRef] 
98. Manning, J.C. Diversity of endothecial patterns in angiosperms. In The Anther: Form, Function and Phylogeny, 1st ed.; D'Arcy, W.G., Keating, R.C., Eds.; Cambridge University Press: Cambridge, UK, 1996; pp. 136-158.

99. Mitsuda, N.; Seki, M.; Shinozaki, K.; Ohme-Takagi, M. The NAC transcription 939 factors NST1 and NST2 of Arabidopsis regulate secondary wall thickenings and are 940 required for anther dehiscence. Plant Cell 2005, 17, 2993-3006. [CrossRef]

100. Wang, H.; Mao, Y.; Yang, J.; He, Y. TCP24 modulates secondary cell wall thickening and anther endothecium development. Front. Plant Sci. 2015, 6, 436. [CrossRef] [PubMed]

101. Bonner, L.; Dickinson, H. Anther dehiscence in Lycopersicon esculentum Mill. New Phytol. 1989, 113, 97-115. [CrossRef]

102. De Craene, L.P.R. The evolutionary significance of homeosis in flowers: A morphological perspective. Int. J. Plant Sci. 2003, 164, S225-S235. [CrossRef]

103. Percival, M.S. The presentation of pollen in certain angio-sperms and its collection by Apis Mellifera. New Phytol. 1955, 3, 353-368. [CrossRef]

104. Denisow, B.; Antoń, S.; Szymczak, G. The flowering, pollen production, and insect visitors in the ornamental shrub Potentilla fruticosa L. (Rosaceae). J. Apic. Res. 2013, 57, 95-106. [CrossRef]

105. Masierowska, M. Early floral resources for urban bees from ornamental shrubs Ribes Aureum, Ribes Sanguineum and Staphylea Pinnata. J. Apic. Sci. 2020, 64, 309-320.

106. Sawyer, R. Pollen Identification for Beekeepers, 1st ed.; Northern Bee Books: West Yorkshire, UK, 2006; p. 112.

107. Wignall, V.R.; Arscott, N.A.; Nudds, H.E.; Squire, A.; Green, T.O.; Ratnieks, F.L. Thug life: Bramble (Rubus fruticosus L.) is a valuable foraging resource for honeybees and diverse flower-visiting insects. Insect Conserv. Divers. 2020, 13, 543-557. [CrossRef]

108. Colbert, S.; De Oliveira, D. Influence of pollen variety on raspberry (Rubus idaeus L.) development. J. Hered. 1990, 81, 434-437. [CrossRef]

109. Cane, J.H. Pollination potential of the bee Osmia aglaia for cultivated red raspberries and blackberries (Rubus: Rosaceae). HortScience 2005, 40, 1705-1708. [CrossRef]

110. Tuohimetsä, S.; Hietaranta, T.; Uosukainen, M.; Kukkonen, S.; Karhu, S. Fruit development in artificially self-and cross-pollinated strawberries (Fragaria $\times$ ananassa) and raspberries (Rubus idaeus). Acta Agric. Scand. Soil Plant Sci. 2014, 64, 408-415. [CrossRef]

111. Żurawicz, E.; Studnicki, M.; Kubik, J.; Pruski, K. A careful choice of compatible pollinizers significantly improves the size of fruits in red raspberry (Rubus idaeus L.). Sci. Hortic. 2018, 235, 253-257. [CrossRef]

112. Lye, G.C.; Jennings, S.N.; Osborne, J.L.; Goulson, D. Impacts of the use of nonnative commercial bumble bees for pollinator supplementation in raspberry. J. Econ. Entomol. 2011, 104, 107-114. [CrossRef]

113. Andrikopoulos, C.J.; Cane, J.H. Comparative pollination efficacies of five bee species on raspberry. J. Econ. Entomol. 2018, 111, 2513-2519. [CrossRef] [PubMed]

114. Tasei, J.N.; Aupinel, P. Nutritive value of 15 single pollens and pollen mixes tested on larvae produced by bumblebee workers (Bombus terrestris, Hymenoptera: Apidae). Apidologie 2008, 39, 397-409. [CrossRef]

115. Gabriele, M.; Parri, E.; Felicioli, A.; Sagona, S.; Pozzo, L.; Domenici, V.; Pucci, L. Phytochemical composition and antioxidant activity of Tuscan bee pollen of different botanic origins. Ital. J. Food Sci. 2015, 27, 248-259. [CrossRef]

116. Sagona, S.; Pozzo, L.; Peiretti, P.G.; Biondi, C.; Giusti, M.; Gabriele, M.; Pucci, L.; Felicioli, A. Palynological origin, chemical composition, lipid peroxidation and fatty acid profile of organic Tuscanian bee-pollen. J. Apic. Res. 2017, 56, 136-143. [CrossRef]

117. Kleinschmidt, G.; Kondos, A. The influence of crude protein levels ion colony production. Austral. Beek. 1976, 78, 36-39.

118. Alaux, C.; Ducloz, F.; Crauser, D.; Le Conte, Y. Wpływ diety na immunokompetencję pszczół. Biol. Łotysz 2010, 6, 562-565. [CrossRef]

119. DeGrandi-Hoffman, G.; Chen, Y.; Huang, E.; Huang, M.H. The effect of diet on protein concentration, hypopharyngeal gland development and virus load in worker honey bees (Apis mellifera L.). J. Insect Physiol. 2010, 56, 1184-1191. [CrossRef]

120. Amdam, G.V.; Norberg, K.; Hagen, A.; Omholt, S.W. Social exploitation of vitellogenin. Proc. Natl. Acad. Sci. USA 2003, 100, 1799-1802. [CrossRef]

121. Koywiwattrakul, P.; Sittipraneed, S. Expression of vitellogenin and transferrin in activated ovaries of worker honey bees. Apis mellifera. Biochem. Genet. 2009, 47, 19-26. [CrossRef] [PubMed]

122. Bitondi, M.M.G.; Simões, Z.L.P. The relationship between level of pollen in the diet, vitellogenin and juvenile hormone titers in africanized Apis mellifera workers. J. Apic. Res. 1996, 35, 27-36. [CrossRef]

123. Amdam, G.V.; Omholt, S.W. The regulatory anatomy of honeybee lifespan. J. Theor. Biol. 2002, 216, 209-228. [CrossRef] [PubMed]

124. Rodríguez-García, C.; Heerman, M.C.; Cook, S.C.; Evans, J.D.; DeGrandi-Hoffman, G.; Banmeke, O.; Zhang, Y.; Huang, S.; Hamilton, M.; Chen, Y.P. Transferrin-mediated iron sequestration suggests a novel therapeutic strategy for controlling Nosema disease in the honey bee, Apis mellifera. PLoS Pathog. 2021, 17, e1009270. [CrossRef] [PubMed]

125. Corona, M.; Velarde, R.A.; Remolina, S.; Moran-Lauter, A.; Wang, Y.; Hughes, K.A.; Robinson, G.E. Vitellogenin, juvenile hormone, insulin signaling, and queen honey bee longevity. Proc. Natl. Acad. Sci. USA 2007, 104, 7128-7133. [CrossRef] [PubMed]

126. Nelson, C.M.; Ihle, K.E.; Fondrk, M.K.; Page Jr, R.E.; Amdam, G.V. The gene vitellogenin has multiple coordinating effects on social organization. PLoS Biol. 2007, 5, 62. [CrossRef] [PubMed]

127. Szczesna, T. Protein content and amino acids composition of bee-collected pollen originating from Poland, South Korea and China. J. Apic. Sci. 2006, 50, 91-99. 
128. Chwil, M. Struktura nektarników kwiatowych i wartość pszczelarska wybranych gatunków roślin z podrodziny Prunoideae (Rosaceae)/Structure of flower nectaries and beekeeping value of plant factors from the subfamily Prunoideae (Rosaceae). Habilitation Thesis, Wydawnictwo Uniwersytetu Przyrodniczego, Lublin, Poland, 2013; p. 108. (in Polish).

129. Al-Kahtani, S.N.; Taha, E.K.; Khan, K.A.; Ansari, M.J.; Farag, S.A.; Shawer, D.; Elnabawy, E.M. Effect of harvest season on the nutritional value of bee pollen protein. PLoS ONE 2020, 15, e241393. [CrossRef] [PubMed]

130. Human, H.; Nicolson, S.W. Nutritional content of fresh, bee-collected and stored pollen of Aloe greatheadii var. davyana (Asphodelaceae). Phytochemistry 2006, 67, 1486-1492. [CrossRef]

131. Block, K.P. Interactions among leucine, isoleucine, and valine with special reference to the branched-chain amino acid antagonism. In Absorption and Utilization of Amino Acids, 1st ed.; Friedman, M., Ed.; CRC Press: Boca Raton, FL, USA, 2019; pp. 229-244. [CrossRef]

132. Green, C.R.; Wallace, M.; Divakaruni, A.S.; Phillips, S.A.; Murphy, A.N.; Ciaraldi, T.P.; Metallo, C.M. Branched-chain amino acid catabolism fuels adipocyte differentiation and lipogenesis. Nat. Chem. Biol. 2016, 12, 15-21. [CrossRef]

133. McCormack, S.E.; Shaham, O.; McCarthy, M.A.; Deik, A.A.; Wang, T.J.; Gerszten, R.E.; Clish, C.B.; Mootha, V.K.; Grinspoon, S.K.; Fleischman, A. Circulating branched chain amino acid concentrations are associated with obesity and future insulin resistance in children and adolescents. Pediatr. Obes. 2013, 8, 52-61. [CrossRef] [PubMed]

134. Yu, D.; Richardson, N.E.; Green, C.L.; Spicer, A.B.; Murphy, M.E.; Flores, V.; Jang, C.; Kasza, I.; Nikodemova, M.; Wakai, M.H.; et al. The adverse metabolic effects of branched-chain amino acids are mediated by isoleucine and valine. Cell Metab. 2021, 33, 905-922 [CrossRef] [PubMed]

135. Carter, C.; Shafir, S.; Yehonatan, L.; Palmer, R.G.; Thornburg, R. A novel role for proline in plant floral nectars. Naturwissenschaffen 2006, 93, 72-79. [CrossRef] [PubMed]

136. Gualano, A.B.; Bozza, T.; Lopes De Campos, P.; Roschel, H.; Dos Santos Costa, A.; Luiz Marquezi, M.; Benatti, F.; Herbert Lancha Junior, A. Branched-chain amino acids supplementation enhances exercise capacity and lipid oxidation during endurance exercise after muscle glycogen depletion. J. Sports Med. Phys. Fitness. 2011, 51, 82-88. [PubMed]

137. Melville, G.W.; Siegler, J.C.; Marshall, P.W. The effects of D-aspartic acid supplementation in resistance-trained men over a three month training period: A randomised controlled trial. PLoS ONE 2017, 12, e0182630. [CrossRef]

138. Roshanzamir, F.; Safavi, S.M. The putative effects of D-aspartic acid on blood testosterone levels: A systematic review. Int. J. Reprod. Biomed. 2017, 15, 1-10. [CrossRef]

139. Patri, M. Synaptic transmission and amino acid neurotransmitters. In Neurochemical Basis of Brain Function and Dysfunction, 1st ed.; Heinbocker, T., Tsoka, A.B., Eds.; IntechOpen: London, UK, 2019. [CrossRef]

140. Bauer, D.; Hamacher, K.; Bröer, S.; Pauleit, D.; Palm, C.; Zilles, K.; Coenen, H.; Langen, K.J. Preferred stereoselective brain uptake of d-serine-a modulator of glutamatergic neurotransmission. Nucl. Med. Biol. 2005, 32, 793-797. [CrossRef]

141. Li, P.; Yin, Y.L.; Li, D.; Kim, S.W.; Wu, G. Amino acids and immune function. Br. J. Nutr. 2007, 98, 237-252. [CrossRef]

142. Bastings, J.J.; van Eijk, H.M.; Olde Damink, S.W.; Rensen, S.S. D-amino acids in health and disease: A focus on cancer. Nutrients 2019, 11, 2205. [CrossRef]

143. Hashimoto, A.; Nishikawa, T.; Hayashi, T.; Fujii, N.; Harada, K.; Oka, T.; Takahashi, K. The presence of free D-serine in rat brain. Fed. Eur. Dioch. Soc. 1992, 296, 33-36. [CrossRef]

144. Mori, H.; Inoue, R. Serine racemase knockout mice. Chem. Biodivers. 2010, 7, 1573-1578. [CrossRef]

145. Biancucci, M.; Mattioli, R.; Forlani, G.; Funck, D.; Costantino, P.; Trovato, M. Role of proline and GABA in sexual reproduction of angiosperms. Front. Plant Sci. 2015, 6, 680. [CrossRef]

146. Mattioli, R.; Biancucci, M.; El Shall, A.; Mosca, L.; Costantino, P.; Funck, D.; Trovato, M. Proline synthesis in developing microspores is required for pollen development and fertility. BMC Plant Biol. 2018, 18, 356. [CrossRef]

147. Kaur, G.; Asthir, B.J.B.P. Proline: A key player in plant abiotic stress tolerance. Biol. Plant. 2015, 59, 609-619. [CrossRef]

148. Mardirossian, M.; Sola, R.; Beckert, B.; Collis, D.W.; Di Stasi, A.; Armas, F.; Hilpert, H.; Wilson, D.N.; Scocchi, M. Proline rich peptides with improved antimicrobial activity against E. coli, K. pneumoniae, and A. baumannii. ChemMedChem 2019, 14, 2025-2033. [CrossRef]

149. Bayram, N.E.; Gercek, Y.C.; Çelik, S.; Mayda, N.; Kostić, A.Ž.; Dramićanin, A.M.; Özkök, A. Phenolic and free amino acid profiles of bee bread and bee pollen with the same botanical origin-similarities and differences. Arab. J. Chem. 2021, 14, 103004. [CrossRef]

150. Petersen, K.F.; Dufour, S.; Cline, G.W.; Shulman, G.I. Regulation of hepatic mitochondrial oxidation by glucose-alanine cycling during starvation in humans. J. Clin. Investig. 2019, 129, 4671-4675. [CrossRef] [PubMed]

151. Leij-Halfwerk, S.; Dagnelie, P.C.; van den Berg, J.W.O.; Wattimena, J.D.L.; Hordijk-Luijk, C.H.; Wilson, J.P. Weight loss and elevated gluconeogenesis from alanine in lung cancer patients. Am. J. Clin. Nutr. 2000, 71, 583-589. [CrossRef] [PubMed]

152. Miyake, Y.; Iwasaki, Y.; Terada, R.; Okamaoto, R.; Ikeda, H.; Makino, Y.; Kobashi, H.; Takaguchi, K.; Sakaguchi, K.; Shiratori, Y. Persistent elevation of serum alanine aminotransferase levels leads to poor survival and hepatocellular carcinoma development in type 1 autoimmune hepatitis. Aliment. Pharmacol. Ther. 2006, 24, 1197-1205. [CrossRef] [PubMed]

153. $\mathrm{Xu}$, T.L.; Gong, N. Glycine and glycine receptor signaling in hippocampal neurons: Diversity, function and regulation. Prog. Neurobiol. 2010, 91, 349-361. [CrossRef] [PubMed]

154. Pérez-Torres, I.; María Zuniga-Munoz, A.; Guarner-Lans, V. Beneficial effects of the amino acid glycine. Mini. Rev. Med. Chem. 2017, 17, 15-32. [CrossRef] 
155. Razak, M.A.; Begum, P.S.; Viswanath, B.; Rajagopal, S. Multifarious beneficial effect of nonessential amino acid, glycine: A review. Oxid. Med. Cell. Longev. 2017, 718, 73-91. [CrossRef] [PubMed]

156. Brosnan, M.E.; Brosnan, J.T. Histidine metabolism and function. J. Nutr. 2020, 150, 2570S-2575S. [CrossRef] [PubMed]

157. Ma, E.H.; Bantug, G.; Griss, T.; Condotta, S.; Johnson, R.M.; Samborska, B.; Mainolfi, N.; Suri, V.; Guak, H.; Balmer, M.L.; et al. Serine is an essential metabolite for effector T cell expansion. Cell Metab. 2017, 25, 345-357. [CrossRef]

158. Xu, N.; Chen, G.; Liu, H. Antioxidative categorization of twenty amino acids based on experimental evaluation. Molecules 2017, 22, 2066. [CrossRef] [PubMed]

159. Hernández, M.L.; Lima-Cabello, E.; Alché, J.D.D.; Martínez-Rivas, J.M.; Castro, A.J. Lipid composition and associated gene expression patterns during pollen germination and pollen tube growth in olive (Olea europaea L.). Plant Cell. Physiol. 2020, 61, 1348-1364. [CrossRef]

160. Anjos, O.; Paula, V.; Delgado, T.; Estevinho, L. Influence of the storage conditions on the quality of bee pollen. Zemdirbyste 2019, 106, 87-94. [CrossRef]

161. Farah, J.; Choël, M.; De Nadaï, P.; Gosselin, S.; Petitprez, D.; Baroudi, M.; Visez, N. Extractable lipids from Phleum pratense pollen grains and their modifications by ozone exposure. Aerobiologia 2020, 36, 171-182. [CrossRef]

162. Bashir, M.E.H.; Lui, J.H.; Palnivelu, R.; Naclerio, R.M.; Preuss, D. Pollen lipidomics: Lipid profiling exposes a notable diversity in 22 allergenic pollen and potential biomarkers of the allergic immune response. PLoS ONE 2013, 8, e57566. [CrossRef]

163. Shakya, R.; Bhatla, S.C. A comparative analysis of the distribution and composition of lipidic constituents and associated enzymes in pollen and stigma of sunflower. Sex. Plant Reprod. 2010, 23, 163-172. [CrossRef]

164. Manning, R.; Harvey, M. Fatty acids in honeybee-collected pollens from six endemic Western Australian eucalypts and the possible significance to the Western Australian beekeeping industry. Aust. J. Exp. Agric. 2002, 42, 217-223. [CrossRef]

165. Leaf, A. The electrophysiologic basis for the antiarrhythmic and anticonvulsant effects of $n-3$ polyunsaturated fatty acids: Heart and brain. Lipids 2001, 36, S107-S110. [CrossRef] [PubMed]

166. Morais, M.; Moreira, L.; Feás, X.; Estevinho, L.M. Honeybee-collected pollen from five Portuguese Natural Parks: Palynological origin, phenolic content, antioxidant properties and antimicrobial activity. Food Chem. Toxicol. 2011, 49, 1096-1101. [CrossRef] [PubMed]

167. Zheng, R.H.; Su, S.D.; Xiao, H.; Tian, H.Q. Calcium: A critical factor in pollen germination and tube elongation. Int. J. Mol. Sci. 2019, 20, 420. [CrossRef] [PubMed]

168. Steinhorst, L.; Kudla, J. Calcium-a central regulator of pollen germination and tube growth. Biochim. Biophys. Acta Mol. Cell Res. 2013, 1833, 1573-1581. [CrossRef] [PubMed]

169. Lau, T.C.; Stephenson, A.G. Effects of soil phosphorus on pollen production, pollen size, pollen phosphorus content, and the ability to sire seeds in Cucurbita pepo (Cucurbitaceae). Sex. Plant Reprod. 1994, 7, 215-220. [CrossRef]

170. Lankinen, $\AA$. Effects of soil $\mathrm{pH}$ and phosphorus on in vitro pollen competitive ability and sporophytic traits in clones of Viola tricolor. Int. J. Plant Sci. 2000, 161, 885-893. [CrossRef]

171. Zonia, L.; Cordeiro, S.; Tupý, J.; Feijó, J.A. Oscillatory chloride efflux at the pollen tube apex has a role in growth and cell volume regulation and is targeted by inositol 3, 4, 5, 6-tetrakisphosphate. Plant Cell 2002, 14, 2233-2249. [CrossRef]

172. Matveyeva, N.P.; Andreyuk, D.S.; Yermakov, I.P. Transport of $\mathrm{Cl}^{-}$across the plasma membrane during pollen grain germination in tobacco. Biochemistry 2003, 68, 1247-1251. [CrossRef] [PubMed]

173. Breygina, M.A.; Matveyeva, N.P.; Andreyuk, D.S.; Yermakov, I.P. Transmembrane transport of $\mathrm{K}^{+}$and $\mathrm{Cl}^{-1}$ during pollen grain activation in vivo and in vitro. Russ. J. Dev. Biol. 2012, 43, 85-93. [CrossRef]

174. Sawidis, T.; Baycu, G.; Weryszko-Chmielewska, E.; Sulborska, A. Impact of manganese on pollen germination and tube growth in lily. Acta Agrobot. 2021, 74, 1-17. [CrossRef]

175. Li, L.G.; Sokolov, L.N.; Yang, Y.H.; Li, D.P.; Ting, J.; Pandy, G.K.; Luan, S. A mitochondrial magnesium transporter functions in Arabidopsis pollen development. Mol. Plant 2008, 1, 675-685. [CrossRef]

176. Chen, J.; Li, L.G.; Liu, Z.H.; Yuan, Y.J.; Guo, L.L.; Mao, D.D.; Tian, L.F.; Chen, B.D.; Luan, S.; Li, D.P. Magnesium transporter AtMGT9 is essential for pollen development in Arabidopsis. Cell Res. 2009, 19, 887-898. [CrossRef] [PubMed]

177. Xu, X.F.; Wang, B.; Lou, Y.; Han, W.J.; Lu, J.Y.; Li, D.D.; Li, L.G.; Zhu, J.; Yang, Z.N. Magnesium transporter 5 plays an important role in Mg transport for male gametophyte development in Arabidopsis. Plant J. 2015, 84, 925-936. [CrossRef] [PubMed]

178. Li, J.; Huang, Y.; Tan, H.; Yang, X.; Tian, L.; Luan, S.; Chen, L.; Li, D. An endoplasmic reticulum magnesium transporter is essential for pollen development in Arabidopsis. Plant Sci. 2015, 231, 212-220. [CrossRef] [PubMed]

179. Xu, X.F.; Qian, X.X.; Wang, K.Q.; Yu, Y.H.; Guo, Y.Y.; Zhao, X.; Wang, B.; Yang, N.Y.; Huang, J.R.; Yang, Z.N. Slowing development facilitates Arabidopsis mgt mutants to accumulate enough magnesium for pollen formation and fertility restoration. Front. Plant Sci. 2021, 11, 2299. [CrossRef]

180. Morgano, M.A.; Martins, M.C.T.; Rabonato, L.C.; Milani, R.F.; Yotsuyanagi, K.; Rodriguez-Amaya, D.B. A comprehensive investigation of the mineral composition of brazilian bee pollen: Geographic and seasonal variations and contribution to human diet. J. Braz. Chem. Soc. 2012, 23, 727-736. [CrossRef]

181. Brodschneider, R.; Crailsheim, K. Nutrition and health in honey bees. Apidologie 2010, 41, 278-294. [CrossRef] 
182. Taha, E.K.A. Chemical composition and amounts of mineral elements in honeybee-collected pollen in relation to botanical origin. J. Apic. Sci. 2015, 59, 75-81. [CrossRef]

183. Wright, G.A.; Nicolson, S.W.; Shafir, S. Nutritional physiology and ecology of honey bees. Annu. Rev. Entomol. 2018, 63, 327-344. [CrossRef] 